UNIVERSIDADE DE SÃO PAULO

FACULDADE DE ZOOTECNIA E ENGENHARIA DE ALIMENTOS

THIAGO JHONATHA FERNANDES SILVA

AVALIAÇÃO DA EFICÁCIA DE DIFERENTES PROTOCOLOS DE

LAVAGEM PERITONEAL EM COBAIAS (Cavia porcellus) COM

PERITONITE SÉPTICA INDUZIDA

Pirassununga 
THIAGO JHONATHA FERNANDES SILVA

\title{
AVALIAÇÃO DA EFICÁCIA DE DIFERENTES PROTOCOLOS DE LAVAGEM PERITONEAL EM COBAIAS (Cavia porcellus) COM PERITONITE SÉPTICA INDUZIDA
}

\author{
Versão corrigida
}

Dissertação de mestrado apresentado à Faculdade de Zootecnia e Engenharia de Alimentos da Universidade de São Paulo, como requisito para a obtenção do Título de Mestre em Ciência Animal.

Área de Concentração: Biociência Animal

Orientadora: Profa. Dra. Renata Gebara Sampaio Dória 


\title{
AVALIAÇÃO DA EFICÁCIA DE DIFERENTES PROTOCOLOS DE LAVAGEM PERITONEAL EM COBAIAS (Cavia porcellus) COM PERITONITE SÉPTICA INDUZIDA
}

\author{
Dissertação de mestrado apresentado à \\ Faculdade de Zootecnia e Engenharia de \\ Alimentos da Universidade de São Paulo, \\ como requisito para a obtenção do Título de \\ Mestre em Ciência Animal. \\ Área de Concentração: Biociência Animal \\ Orientadora: Profa. Dra. Renata Gebara \\ Sampaio Doria
}

Data de aprovação:

Banca Examinadora:

Prof. Dr.

Instituição

Presidente da Banca Examinadora

Prof.(a) Dr.(a)

Instituição

Prof.(a) Dr.(a)

Instituição 
Ficha catalográfica elaborada pelo Serviço de Biblioteca e Informação, FZEA/USP, com os dados fornecidos pelo(a) autor(a)

\begin{tabular}{|c|c|}
\hline \multirow{4}{*}{ S586a } & SILVA, THIAGO JHONATHA FERNANDES \\
\hline & $\begin{array}{l}\text { Avaliação da eficácia de diferentes protocolos de lavagem } \\
\text { peritoneal em cobaias (Cavia porcellus) com peritonite séptica } \\
\text { induzida / THIAGO JHONATHA FERNANDES SILVA ; } \\
\text { orientadora Renata Gebara Sampaio Doria. -- Pirassununga, } 2019 \\
84 \text { f. }\end{array}$ \\
\hline & $\begin{array}{l}\text { Dissertação (Mestrado - Programa de Pós-Graduação em } \\
\text { Biociência Animal) -- Faculdade de Zootecnia e Engenharia de } \\
\text { Alimentos, Universidade de São Paulo. }\end{array}$ \\
\hline & $\begin{array}{l}\text { 1. Peritonite séptica. 2. Lavagem peritoneal. 3. Solução de } \\
\text { lidocaína, heparina e carboximetilcelulose. 4. Avaliação sérica e } \\
\text { peritoneal. 5. Modelo experimental, Cavia porcellus. I. Gebara } \\
\text { Sampaio Dória, Renata, orient. II. Título. }\end{array}$ \\
\hline
\end{tabular}

Permitida a cópia total ou parcial deste documento, desde que citada a fonte - o autor 


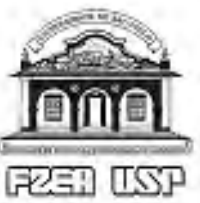

UNIVERSIDADE DESÃO PAULO

Faculdode de zectecric e Encenhoria de Aimentos Comité de Éca om Pesquisa da FZEA

\section{CERTIFICADO}

Certificamos que a proposta intitulada "AVALACÇÄO DA EFICACIA DE DIFERENTES PROTOCOLOS DE DIALISE PERITONEAL EM COBAIAS COM PERITONITE FECAL"; protocolada sob o CEUA n 4183271017 iD wos411, sob a responsabilidade de Renata Gebara Sampaio Dória - que envolve a produçâo, manutenção e/ou utilizaçâo de animais pertencentes ao filo Chordata, subfilo Vertebrata (exceto o homem), para fins de pesquisa cientifica ou ensino - está de acordo com os preceitos da Lei 11.794 de 8 de outubro de 2008 , com o Decreto 6.899 de 15 de julho de 2009, bem como com as normas editadas pelo Conselho Nacional de Controle da Experimentaçāo Animal (CONCEA), e foi aprovada pela Comisșão de Ética no Uso de Animais da Faculdade de Zootecnia e Engenharia de Alimentos da Universidade de São Paulo - FZEA/USP (CEUA/FZEA) na reunião de 09/03/2018.

We certify that the proposal "EVALUATION OF THE EFFECTIVENESS OF DIFFERENT PROTOCOLS OF PERITONEAL DIALYSIS IN COBIASES WITH FECAL PERITONITE", utilizing 46 Guinea pigs (males and females), protocol number CEUA 4183271017 nD 000841 . under the responsibility of Renata Gebara Sampaio Dória - which involves the production, maintenance and/or use of animals belonging to the phylum Chordata, subphylum Vertebrata (except human beings), for scientific research purposes or teaching - is in accordance with Law 11.794 of October B, 2008, Decree 6899 of July 15, 2009, as well as with the rules issued by the National Council for Control of Animal Experimentation (CONCEA), and was approved by the Ethic Committee on Animal Use of the School of Animal Science and Food Engineering - (Saao Paulo University) (CEUAVZZEA) in the meeting of 03/09/2018.

Finalidade da Proposta: Pesquisa (Acadèmica)

Vigéncia da Proposta: de 04/2018 a 12/2018_Área: Medicina Veterinária

Origem: Animais provenientes de estabelecimentos comerciais
Espécie: Cobaias
5exo: Machos e Fêmeas
idade: 8 a 10 semanas
N: $\quad 46$

Linhagem: Dunkan-Hartley

Peso: 250 a $500 \mathrm{~g}$

Local do experimento: Anexo do Laboratório de pesquisa em clínica, cirurgia e reabilitação de equinos (Campus Femando Costa) FZEAYUSP)

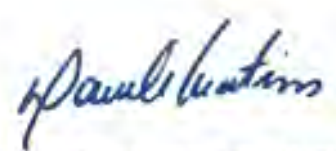

Profa. Dra. Daniele dos Santos Martins

Coordenadora da Comissáo de Etica no Uso de Animais Faculdade de Zootecnia e Engenharia de Alimentos da Universidade de São Paulo - FZEANUSP

, 


\section{DEDICATÓRIA}

Dedico este trabalho aos clínicos e cirurgiões que não desistem de buscar novos métodos terapêuticos, mesmo frente aos desafios impostos pelas eventualidades da rotina no sacerdócio da medicina equina. 


\section{AGRADECIMENTOS}

Agradeço a Deus as oportunidades concedidas, toda equipe espiritual que nós dá o suporte para o desenvolvimento das atividades neste plano.

Aos meus pais Genival Silva e Albanir Fernandes por acreditarem em cada sonho e na luta diária somando esforços com todo incentivo para que toda caminhada fosse segura estando realizados em cada etapa superada.

À minha esposa e companheira de ciência Waldelucy Felix pelo apoio em todos os momentos, sejam eles experimentais, na carreira ou na vida pessoal. Nos momentos onde tudo correu como planejado, bem como nos momentos de aflição que norteiam nossa caminhada, pela companhia, paciência e parceria meu muito obrigado, sem você não aconteceria da forma que aconteceu.

À minha orientadora $\operatorname{Prof}^{\mathrm{a}} \operatorname{Dr}^{\mathrm{a}}$ Renata Gebara Sampaio Dória, que contribuiu substancialmente para a construção deste trabalho, construiu conjuntamente ensinamentos que vão além da clinica médica e cirúrgica, sendo meu modelo para a condução de futuros trabalhos. Pela paciência, dedicação e sem medir esforços para a realização de cada etapa experimental, somando em todas as etapas, construindo um pós-graduando. Seus conselhos e ensinamentos fizeram e fazem a diferença no meu dia a dia, aprendi lições de valor inestimável, a Sra. agradeço de coração tudo que fez por mim, serei sempre grato.

À Prof ${ }^{a} \operatorname{Dr}^{\mathrm{a}}$ Maria de Fátima, que foi não somente uma colaboradora do projeto, mas também uma grande entusiasta da produção científica, foi muito além da cessão de espaço para a realização da fase experimental, cedeu sua equipe, buscou interagir durante o decorrer do projeto, sempre preocupada com os detalhes.

Aos professores Dr. Rodrigo Romero, Dr. Hary Birgel e Dra ${ }^{\mathrm{a}}$. Paula di Filippo, pelas instruções e colaborações durante a qualificação do projeto, somando com experiência e vivência no mundo da clínica de grandes animais, ao incentivo o meu agradecimento.

Ao professor Dr. Ricardo Moro, pela cessão do laboratório para que fossem realizadas testes e análises, sendo um dos grandes parceiros na realização deste trabalho, ainda pelos incentivos e sempre com uma palavra amiga para auxiliar.

Aos professores Dr ${ }^{\mathrm{a}}$. Gesiane Ribeiro e Dr. Cahuê Paz, pelas significativas contribuições durante a defesa do trabalho, que brilhantemente somaram no ajuste final do trabalho, para engrandecer o estudo realizado com o detalhamento que uma equipe científica busca.

Ao amigo Renan Grigoletto que incentivou e me abriu portas no desenvolvimento da pósgraduação.

Aos companheiros de pós-graduação, que dividiram muitos momentos durante a etapa préexperimental, eles tornaram menos seca a vivência dentro do ambiente científico, sempre podendo contar com eles independente da necessidade. 
Aos companheiros do grupo de pesquisa que muito me somaram tão quanto dividiram suas experiências, desenvolvendo de forma coletiva a produção científica aliada a clínica médica e cirúrgica de equinos no hospital da FZEA-USP.

Aos técnicos Neimar dos Santos, Danielle Passarelli e Claúdia Scatolini, pelo auxílio em todas as etapas do projeto, vocês muito auxiliaram um pós graduando que nada conhecia desta instituição a desbravar os caminhos dentro da FZEA-USP, fizeram o caminho ser menos tortuoso com a dose exata de colaboração.

À amiga e bolsista de iniciação a pesquisa Thatiane Castro, que esteve junto em todas as fases do projeto, nos percalços e nas alegrias sempre acreditando no sucesso do projeto, bem como ao amigo e colaborador Bruno Yokota, que muito nos auxiliou nas diversas etapas do projeto, pelo enorme carinho com os animais e dedicação em realizar cada tarefa, ainda a amiga e colaboradora Mariana Landi que sempre esteve à disposição em todas as etapas, companheira de todas as horas, parceira na execução do projeto com imensa dedicação vestindo a camisa da equipe, vocês colaboraram de maneira entusiasmante, à isso o meu mais profundo agradecimento.

Agradeço ainda à colaboradora e companheira de jornada Ana Laura que sempre se colocou a disposição para realizar as tarefas atribuídas com muita dedicação, sempre com ótimo humor ainda que cansada, à colaboradora Ana Carolina sempre disposta todas as vezes que foi solicitada, esteve conosco realizando as atividades solicitadas em parceria, somando muito a equipe e com ânimo nos horários de maior cansaço da equipe. Por fim agradeço também a colaboradora Elisa Lima que com todo empenho somou a equipe de trabalho deste projeto. A estes companheiros de jornada sempre falei que ninguém é insubstituível, mas sem eles esta caminhada científica haveria sido mais labiríntica. 


\section{RESUMO}

SILVA, T. J. F. Avaliação da eficácia de diferentes protocolos de lavagem peritoneal em cobaias (Cavia porcellus) com peritonite séptica induzida. 2019. 70p. Dissertação (Mestrado) - Faculdade de Zootecnia e Engenharia de Alimentos, Universidade de São Paulo, Pirassununga, 2019.

A síndrome cólica é a afecção que mais leva equinos a intervenções clínico-cirúrgicas, sendo uma das complicações a peritonite por contaminação fecal, que quando instalada, o procedimento de lavagem peritoneal se faz necessário, buscando reduzir a quantidade de patógenos presentes no abdômen, mediadores inflamatórios e fatores de coagulação, que induzem à formação de aderências viscerais. Esta pesquisa busca avaliar a efetividade de protocolo inovador de lavagem peritoneal, em modelo de indução de peritonite fecal, em cobaias (Cavia porcellus), elevando a taxa de sobrevida nesta afecção. Foi realizada validação do modelo de indução de peritonite fecal, com injeção intraperitoneal de $5 \mathrm{~mL} / \mathrm{kg}$ de uma suspensão composta por fezes autólogas filtradas GM ( $n=6)$. Após validação, foram realizados quatro grupos, submetidos a diferentes protocolos de lavagem peritoneal seriados, realizados a cada 8 horas, por sete dias, após indução de peritonite fecal. Os animais do GC $(\mathrm{n}=10)$ foram submetidos à lavagem peritoneal com $30 \mathrm{~mL}$ de ringer lactato; os animais do GL $(\mathrm{n}=10)$ submetidos à lavagem peritoneal com $30 \mathrm{~mL}$ de ringer lactato associado à lidocaína; os animais do GLH (n=10) submetidos à lavagem peritoneal com $30 \mathrm{~mL}$ de ringer lactato associado à lidocaína e heparina e os animais do GLHC $(n=10)$ submetidos à lavagem peritoneal com $30 \mathrm{~mL}$ de ringer lactato associado à lidocaína, heparina e carboximetilcelulose. Todos os grupos foram submetidos à terapia sistêmica convencional de pós-operatório de cólica em equinos. Os dados clínicos, laboratoriais e de avaliação post-mortem demonstraram a eficiência dos tratamentos. Os dados paramétricos foram submetidos à análise estatística pelo teste de análise de variância e teste de Tukey $(\mathrm{p}<0,05)$. Os resultados demonstraram uma elevação na sobrevida quando comparando GC com sobrevida de 20\%, foi possível demonstrar 90\% de sobrevida para o GL e GLH e $80 \%$ para o GLHC, assim os tratamentos demonstraram o impacto significativo clínico e estatístico. Aliados aos resultados laboratoriais do líquido peritoneal com redução significativa para os grupos GL e GLH e na avaliação macro e microscópica trouxeram importantes resultados com a significativa redução de aderências e menor índice de lesões microscópicas à fígado e rim nos mesmos grupos, contribuem para a descrição sugestiva de um protocolo de lavagem peritoneal que impacte da sobrevida de animais acometidos por peritonite séptica. Sendo possível afirmar que nas condições testadas houve impacto na sobrevida dos animais, além de reduzir a quantidade de aderências que frequentemente ocorrem no equino acometido por peritonite.

Palavras chave: Sepse, inflamação abdominal e aderências 


\section{ABSTRACT}

SILVA, T. J. F. Evaluation of the efficacy of different peritoneal lavage protocols in guinea pigs (Cavia porcellus) with induced septic peritonitis. 2019. 70p. Dissertação (Mestrado) - Faculdade de Zootecnia e Engenharia de Alimentos, Universidade de São Paulo, Pirassununga, 2019.

The colic syndrome is the condition that brings the most horses to clinical and surgical interventions. One of the complications is peritonitis due to fecal contamination. When installed, the peritoneal lavage procedure is necessary to reduce the amount of pathogens present in the abdomen, mediators inflammatory and coagulation factors, which induce the formation of visceral adhesions. This research seeks to evaluate the effectiveness of an innovative protocol for peritoneal lavage in a model of fecal peritonitis induction in guinea pigs (Cavia porcellus), increasing the survival rate in this condition. Validation of the fecal peritonitis induction model was performed with intraperitoneal injection of $5 \mathrm{~mL} / \mathrm{kg}$ of a suspension composed of autologous fecal filtrates GM ( $n=6)$. After validation, four groups were submitted to different serial peritoneal lavage protocols performed every 8 hours for seven days after induction of fecal peritonitis. CG animals $(n=10)$ were submitted to peritoneal lavage with $30 \mathrm{~mL}$ lactated ringer; $L G$ animals $(n=10)$ submitted to peritoneal lavage with $30 \mathrm{~mL}$ lactated ringer associated with lidocaine; LHG animals $(n=10)$ underwent peritoneal lavage with $30 \mathrm{~mL}$ lactated ringer associated with lidocaine and heparin and LHCG animals $(\mathrm{n}=10)$ submitted to peritoneal lavage with $30 \mathrm{~mL}$ lactated ringer associated with lidocaine, heparin and carboxymethylcellulose. All groups submitted to conventional systemic therapy of colic postoperative in horses. Clinical, laboratory and post-mortem data will be presented in a descriptive way. The parametric data will be submitted to statistical analysis by the analysis of variance and Tukey test ( $p<0.05)$. The results showed an increase in survival when comparing CG with $20 \%$ survival, it was possible to demonstrate $90 \%$ survival for GL and GLH and $80 \%$ for GLHC, so the treatments demonstrated the significant statistical and clinical impact. Allied to the laboratory results of the peritoneal fluid with significant reduction for the GL and GLH groups and in the macro and microscopic evaluation, they brought important results with the significant reduction of adhesions and lower index of microscopic lesions to the liver and kidney in the same groups, contribute to the suggestive description of a peritoneal lavage protocol that impacts the survival of animals affected by septic peritonitis. It is possible to state that the conditions tested had an impact on the animals' survival, in addition to reducing the amount of adhesions that frequently occur in the horse affected by peritonitis.

Keywords: Sepsis, abdominal inflammation and adhesions 


\section{LISTA DE ABREVIATURAS E SIGLAS}

\begin{tabular}{ll} 
AINE & Antiiflamatórios não esteroidais \\
AST & Aspartato aminotransferase \\
CID & Coagulação Intravascular Disseminada \\
CHCM & Concentração de Hemoglobina Corpuscular Média \\
CMC & Carboximetilcelulose \\
COX & Ciclooxigenases \\
EDTA & Ethylenediamine tetraacetic acid \\
GM & Grupo modelo \\
GC & Grupo controle \\
GL & Grupo lidocaína \\
GLH & Grupo lidocaína Heparina \\
GLHC & Grupo lidocaína Heparina Carboximetilcelulose \\
HCM & Hemoglobina Corpuscular Média \\
IM & Intramuscular \\
MODs & Síndrome da falência múltipla dos órgãos \\
SIRS & Síndrome da resposta inflamatória sistêmica \\
SC & Subcutâneo \\
VCM & Volume Corpuscular Médio \\
VG & Volume Globular \\
VO & Via oral \\
pH & Hematoxilina-eosina Hidrogeniônico \\
HE & \\
\hline
\end{tabular}




\section{LISTA DE FIGURAS}

Figura 1 - Cobaias alojadas em gaiolas individuais.

Figura 2 - Monitoramento remoto dos animais.

Figura 3 - Preparo da solução de indução de peritonite com fezes autólogas.

Figura 4 - Pesagem diária individual dos animais.

Figura 5 - Acessos de localização das sondas.

Figura 6 - Sobrevida em horas dos animais entre grupos.

Figura 7. Avaliação da concentração leucocitária entre tratamentos durante as lavagens peritoneais.

Figura 8 - Dinâmica de neutrófilos segmentados durante os tratamentos.

Figura 9 - Avaliação da ureia sérica durante os tratamentos.

Figura 10 - Avaliação da creatinina sérica durante os tratamentos.

Figura 11 - Avaliação do pH no líquido peritoneal durante os tratamentos.

Figura 12 - Avaliação da proteína no líquido peritoneal durante os tratamentos.

Figura 13 - Avaliação da glicose no líquido peritoneal durante os tratamentos. 
Figura 14 - Variação da celularidade total no liquido peritoneal de cobaias durante os tratamentos.

Figura 15 - Avaliação de macrófagos no líquido peritoneal de cobaias durante os tratamentos.

Figura 16 - Avaliação de neutrófilos no líquido peritoneal de cobaias durante os tratamentos.

Figura 17 - Aspecto da parede abdominal externa sem a presença de foco 52 purulento e/ou aderências.

Figura 18 - Aderências abdominais em animais do Grupo Modelo de Indução (GM), evidenciando aderência entre órgãos e parede abdominal.

Figura 19 - Aderências abdominais em animais do Grupo Controle (GC), 53 evidenciando aderência entre órgãos e a parede abdominal.

Figura 20- Avaliação macroscópica (post mortem) de cobaias.

Figura 21 - Avaliação macroscópica (post mortem) de cobaias (GLHC). 


\section{LISTA DE TABELAS E QUADROS}

Tabela 1 - Avaliação do grau de aderência na cavidade abdominal.

Tabela 2 - Valores médios e desvio padrão da avaliação hematológica dos grupos experimentais.

Tabela 3 - Valores médios e desvio padrão do consumo de ração (g).

Tabela 4 - Valores médios e desvio padrão do consumo de forragem (feno de tifton em gramas) entre os grupos ao longo do período de tratamento entre os grupos ao longo do período de tratamento.

Tabela 5 - Valores médios e desvio padrão do consumo de forragem verde (g) entre os grupos ao longo do período de tratamento.

Tabela 6 - Valores médios e desvio padrão da avaliação hematológica dos grupos experimentais.

Tabela 7 - Valores médios e desvio padrão de leucócito nos grupos experimentais

Tabela 8 - Valores médios e desvio padrão de neutrófilos segmentado nos grupos experimentais

Tabela 9 - Valores médios e desvio padrão de ureia nos grupos experimentais.

Tabela 10 - Valores médios e desvio padrão de creatinina nos grupos experimentais.

Tabela 11 - Valores médios e desvio padrão de AST nos grupos experimentais.

Tabela 12 - Valores de sangue oculto e densidade em líquido peritoneal durante os tratamentos.

Tabela 13 - Valores médios e desvio padrão de pH nos grupos experimentais.

Tabela 14 - Valores médios e desvio padrão de proteína nos grupos experimentais.

Tabela 15 - Valores médios e desvio padrão de glicose nos grupos experimentais.

Tabela 16 - Valores médios e desvio padrão da avaliação para contagem de células total $/ \mu 1(\mathrm{CT})$ 
Tabela 17 - Valores médios e desvio padrão da avaliação para contagem de macrófago/ $\mu \mathrm{L}$

Tabela 18 - Valores médios e desvio padrão da avaliação para contagem de neutrófilo/ $\mu \mathrm{L}$

Quadro 1 - Avaliação clínica/comportamental individual.

Quadro 2 - Sinais clínicos indicativos de dor em roedores.

Quadro 3 - Escala de avaliação e mensuração de dor para cobaias. 


\section{SUMÁRIO}

1. INTRODUÇÃO 17

2. REVISÃO DE LITERATURA 18

$\begin{array}{ll}2.1 \text { Peritônio e a peritonite } & 18\end{array}$

$\begin{array}{ll}2.2 \text { Respostas metabólicas à peritonite } & 19\end{array}$

$\begin{array}{ll}2.3 \text { Diagnóstico da inflamação peritoneal } & 19\end{array}$

2.4 Mecanismo de combate sistêmico à agressão peritoneal 20

2.4.1 Anti-inflamatórios não esteroidais 20

$\begin{array}{ll}2.4 .2 \text { Antibioticoterpaia } & 21\end{array}$

2.5 Mecanismo de combate in loco à agressão peritoneal: lavagem peritoneal 22

2.5.1 Combate local à inflamação peritoneal: lidocaína 22

2.5.2 Combate local à produção de fibrina: heparina 23

2.5.3 Combate local às aderências: carboximetilcelulose 24

2.6 Modelo experimental 25

3. HIPÓTESE 26

4. JUSTIFICATIVA 26

5. OBJETIVOS

5.1 Objetivo geral 26

5.2 Objetivos específicos $\quad 26$

6. MATERIAL E MÉTODOS 27

$\begin{array}{ll}6.1 \text { Animais experimentais } & 27\end{array}$

$\begin{array}{ll}6.2 \text { Procedimento experimental } & 28\end{array}$

6.2.1 Grupos experimentais 28

6.2.2 Indução da peritonite séptica e preparo dos animais para lavagem 29 peritoneal

6.2.3 Lavagem peritoneal 31

6.2.4 Avaliação clínica comportamental 31

6.2.5 Colheita de sangue e líquido peritoneal 34

6.2.6 Avaliação laboratorial de sangue e líquido peritoneal 34

6.2.6.1 Avaliação do fibrinogênio peritoneal 35

6.2.7 Eutanásia 35

6.2.8 Avaliação macroscópica das alterações abdominais 36

6.2.9 Avaliação microscópica de rim e fígado 37 
7. RESULTADOS 38

7.1 Acesso cirúrgico e padronização do volume utilizado nas lavagens 38

Peritoneais

7.1.1. Tempo de procedimento cirúrgico e recuperação anestésica 38

7.2 Avaliação in vivo dos tratamentos com lavagem peritoneal 39 utilizando lidocaína, heparina e carboximetilcelulose

7.2.1 Avaliação clínico comportamental $\quad 39$

7.2.2. Avaliação da dinâmica de consumo de alimento, água e peso entre os 34 tratamentos.

7.3 Avaliação laboratorial sérica e peritoneal 49

7.3.1 Avaliação hematológica 49

7.4 Avaliação bioquímica sérica $\quad 52$

7.5 Avaliação físico química e bioquímica dos líquidos peritoneais 55

7.6 Avaliação macroscópica dos achados abdominais $\quad 62$

7.7 Avaliação histopatológica de rim e fígado 66

8. DISCUSSÃO 68

9. CONCLUSÃO 76

REFERÊNCIAS BIBLIOGRÁFICAS 


\section{INTRODUÇÃO}

A peritonite é uma afecção considerada grave, que acomete diferentes espécies animais, cuja etiologia abrange, desde a inflamação do peritônio por um desequilíbrio fisiológico local até uma peritonite causada por contaminação fecal, como no caso das lacerações intestinais. Apresenta, em mamíferos, elevada mortalidade, principalmente se de origem séptica, devido à toxemia aguda, seguida por sepse.

$\mathrm{Na}$ medicina veterinária, algumas espécies apresentam maior sensibilidade à peritonite, como a espécie equina, que demonstra elevada sensibilidade às interferências em sua cavidade abdominal. Neste ínterim, considerando a elevada casuística clinico-cirúrgica, em equinos, envolvendo a síndrome cólica e, consequentemente, as laparotomias exploratórias, salienta-se a importância da instituição de ampla terapêutica pré, trans e pós-operatória, que vise reduzir os riscos da peritonite séptica e suas consequências.

A absorção de toxinas presentes no abdômen de equinos com peritonite séptica favorece a instalação da endotoxemia e da síndrome da resposta inflamatória sistêmica, a qual culmina com o comprometimento do funcionamento de órgãos, como fígado e rins, que participam diretamente do metabolismo, causando a síndrome da disfunção múltipla dos órgãos e morte dos animais.

Sendo assim, uma vez instalada a peritonite séptica, o procedimento de lavagem peritoneal torna-se interessante, visto que reduziria a quantidade de patógenos e endotoxinas presentes no abdômen e, ao mesmo tempo, reduziria a quantidade local de mediadores inflamatórios e fatores de coagulação, os quais induzem à formação de aderências viscerais.

Neste estudo, propõe-se avaliar, em modelo experimental de indução de peritonite em cobaias, diferentes protocolos de lavagem peritoneal seriada, associados à terapia sistêmica convencional, utilizada em pós-operatório de cólica, em equinos visando reduzir a infecção e inflamação abdominal, formação de aderências viscerais, síndrome da resposta inflamatória sistêmica e síndrome da disfunção múltipla dos órgãos, elevando a taxa de sobrevida a esta afecção. 


\section{REVISÃO DE LITERATURA}

2.1 Peritônio e a peritonite

O peritônio é o tecido que recobre todas as estruturas dentro da cavidade abdominal, sendo formado pelo peritônio parietal, que reveste a parede abdominal e diafragma, e pelo peritônio visceral, que é a continuação da porção parietal e recobre o omento, os órgãos abdominais e forma a superfície serosa do intestino, constituindo-se o maior espaço extravascular pré-formado no corpo (MENDES et al., 2000; JUNQUEIRA \& CARNEIRO, 2004).

O peritônio é umectado por um fluido corpóreo natural, chamado de fluido peritoneal, apresentando-se como um dialisado do sangue, com pH e conteúdo de eletrólitos semelhantes ao do plasma, sendo constantemente produzido e absorvido, e tendo como funções lubrificar a cavidade abdominal, inibir a formação de aderências, além de possuir pequena propriedade antibacteriana (TRENT, 1995; RODRIGUES et al., 2005; LABATO 2011).

A peritonite constitui uma ameaça em potencial à vida dos animais, na medida em que, com elevada frequência, desafia as mais diversas condutas terapêuticas. Entre as possibilidades etiopatogênicas, a peritonite por contaminação fecal constitui causa frequente e grave de peritonite, em especial nos equinos (ALVES, 2002; PAGLIOSA \& ALVES 2004).

Na clínica de equinos, a peritonite por contaminação fecal pode ser resultado de diferentes processos patológicos envolvendo o aparelho digestório. Alterações na barreira intestinal, com translocação bacteriana do lúmen intestinal para a cavidade peritoneal, podem ser causadas por diversos fatores, sendo comum em mucosas intestinais distendidas, inflamadas, assim como nos casos que envolvam a injúria de isquemia-reperfusão, causando desordens que vão desde locais a sistêmicas (ISUN, et al,. 2000; KEUBLER et al., 2003; MUSCH et al., 2005).

Da mesma forma, afecções intestinais cujo tratamento envolva laparotomia exploratória, enterotomia, enterectomia/enteroanastomose, frequentemente, cursam com peritonite fecal no período pós-operatório, o que pode tornar o prognóstico reservado a desfavorável, de acordo com a 
quantidade de material fecal que alcance a cavidade abdominal, como também pode ser observado nos casos de ruptura intestinal ou de ampola retal, além das aderências abdominais, que, não raramente, levam à dor e óbito de equinos (LASKOSKI et al., 2010).

2.2 Respostas metabólicas à peritonite

Concomitantemente à agressão ao peritônio causada pela presença de micro-organismos em casos de peritonite séptica, tem-se o desencadeamento de distúrbios sistêmicos em consequência à infecção abdominal, como a síndrome da resposta inflamatória sistêmica (SIRS) e a síndrome da falência múltipla dos órgãos (MODs) (SALLES et al., 1999), para os quais diversos estudos terapêuticos têm buscado redução da mortalidade, apresentando pouco sucesso (DINARELLO et al., 1993; SALLES et al., 1999). Nestes casos, como indicativo de prognóstico, é possível avaliar os órgãos que participam diretamente do metabolismo, que serão exigidos na recuperação do paciente, como fígado e rins, sendo a função ou disfunção dos mesmos indicativos de sinais de falha orgânica sistêmica (GALLOS et al., 2004; PLUNKETT et al., 2006).

\subsection{Diagnóstico da inflamação peritoneal}

Toda agressão ao peritônio resulta em alteração no líquido peritoneal, sendo a análise do líquido presente na cavidade peritoneal uma ferramenta útil como auxílio diagnóstico e prognóstico nas afecções que envolvam alterações intestinais e ou infecções abdominais (KELLER, 2015).

A abdominocentese, também conhecida como paracentese, permite a colheita do líquido peritoneal para mensuração das características físicas, como volume, cor e aspecto; químicas, como quantidade de proteínas, $\mathrm{pH}$, níveis de lactato e fibrinogênio; e celularidade, quando se avalia a migração de leucócitos, entre eles, neutrófilos, eosinófilos, basófilos, mastócitos, linfócitos e macrófagos, o que determinará o nível de reatividade do peritônio em resposta uma agressão, como em casos de peritonite (FARIA et al., 1999; DI FILIPPO et al., 2009). 
2.4 Mecanismo de combate sistêmico à agressão peritoneal

No combate às agressões peritoneais, algumas estratégias são utilizadas visando modular o dano sistêmico, entre elas está o uso de anti-inflamatórios não esteroidais e antibioticoterapia.

2.4.1 Anti-inflamatórios não esteroidais

Ao se promover uma agressão ao peritônio, inicia-se uma progressiva descamação e transformação das células mesoteliais, as quais promovem quimiotaxia de neutrófilos, liberação de mediadores solúveis da inflamação e diminuição da atividade fibrinolítica. Os mediadores inflamatórios incluem enzimas lisossômicas, histamina, serotonina, prostaglandinas, leucotrienos, fator ativador de plaquetas, citocinas, cínicas, fibrinopeptídeos, radicais de oxigênio, entre outros (BOOTHE, 2003; DIKINSON, 2004).

As prostaglandinas e leucotrienos são dois dos mais importantes mediadores nos processos inflamatórios. Inicialmente, a formação destes mediadores acontece por meio da fosfolipase A2, que advém da ruptura do ácido araquidônico nas membranas celulares. O ácido araquidônico é convertido pela lipoxigenase em leucotrienos e em prostaglandinas pelas cicloxigenases. (CASTELBRANCO, 2013).

Há dois tipos de cicloxigenases, cicloxigenase 1 (COX-1) e cicloxigenase 2 (COX-2), as quais determinam no organismo diferentes funções fisiológicas, sendo que os produtos derivados da quebra do ácido araquidônico pela COX-1 levam à formação de prostaglandinas relacionadas com reações fisiológicas renais, gastrointestinais e vasculares, enquanto os produtos originados pela cisão através da COX-2 levam à formação de prostaglandinas que participam dos eventos inflamatórios (WEBSTER, 2005; CASTEL-BRANCO, 2013).

Visando a redução do processo inflamatório e alívio da dor, faz-se uso de anti-inflamatórios não esteroidais (AINEs), os quais foram introduzidos à clínica médica para tratamento das síndromes dolorosas agudas e crônicas, por meio da inibição das cicloxigenases (ANDRADE, 2008; DAVIS, 2017). 
O flunixin meglumine é um AINE, derivado do ácido carboxílico, que possui grande ação analgésica e anti-inflamatória, sendo o fármaco de escolha para modulação de inflamações peritoneais (MAZZAFARI, 2010; MELGAÇO, et al., 2010; SHELL et al., 2014 ).

\subsubsection{Antibioticoterapia}

Em casos de peritonite, em especial as sépticas, visando o controle de uma infecção sistêmica, faz-se necessário o uso de antibióticos que atuem contra bactérias Gram positivas, Gram negativas e anaeróbias, promovendo, ao mesmo tempo, o controle da endotoxemia.

Recentemente, o Ceftiofur, uma cefalosporina de terceira geração, tem sido o antibiótico mais utilizado na rotina clínica, apresentando amplo espectro de ação, atuando contra bactérias Gram positivas e Gram negativas (ACUNA et al., 2011; VILOS et al., 2015). Apresenta resposta positiva quando associado à gentamicina, um aminoglicosídeo que atua, preferencialmente, sobre bactérias Gram negativas (NEVES et al., 2016), promovendo um reforço ao combate das bactérias de origem fecal (CARNEIRO et al., 2002; PALMA et al., 2005; MACIEL \& XAVIER, 2017). Em se tratando de microorganismos de origem entérica, torna-se interessante, ainda, a associação do metronidazol, um derivado do nitroimidazol, com ação direcionada para bactérias anaeróbias e protozoários (VICENTE \& TRALLERO, 2010).

2.5 Mecanismo de combate in loco à agressão peritoneal: lavagem peritoneal

A lavagem peritoneal representa um recurso clínico auxiliar em casos de peritonite fecal, reduzindo a quantidade de patógenos e endotoxinas presentes no abdômen ao mesmo tempo que reduz a quantidade local de mediadores inflamatórios e fatores de coagulação, que induzem à formação de aderências viscerais (ALVES, 2002; COOPER \& LABATO, 2011).

A membrana peritoneal é semipermeável, heterogênea, contém múltiplos e diferentes poros, possuindo as propriedades de um dialisador (DAUGIRDAS et al., 2003). A lavagem peritoneal é uma prática considerada polêmica em função de promover a suspensão de partículas, carreando contaminação para onde inicialmente não havia , sendo os benefícios decorrentes principalmente da 
remoção de componentes nocivos e indesejáveis da cavidade abdominal, os quais em conjunto, na maioria das vezes, caracterizam um exsudato altamente cáustico ao peritônio (ALVES, 2002; LABATO, 2011).

Tradicionalmente, para lavagem peritoneal, em equinos, utilizam-se soluções poliônicas, sendo a menos agressiva e, portanto, a mais indicada, a de Ringer lactato, por ser balanceada em eletrólitos e possuir pH próximo da neutralidade (ALVES, 2002; CARNEIRO et al., 2002; PALMA et al., 2005; CHACAR et al., 2014).

Associado às soluções poliônicas, o combate in loco à agressão peritoneal segue um curso, em cascata, em três níveis, que visa reduzir a inflamação, que potencialmente reduz a produção de fibrina, que por sua vez reduz a formação de aderências, atuando de maneira sinérgica à terapia sistêmica.

\subsubsection{Combate local à inflamação peritoneal: lidocaína}

A lidocaína é uma amida e como anestésico local, age bloqueando a transmissão neuronal no local do estímulo, atenuando a resposta neurogênica, pode reduzir a lesão celular induzida por citocinas através de mecanismos envolvendo canais de potássio mitocondriais sensíveis a adenosina trifosfato (ATP). A propriedade analgésica da lidocaína pode persistir mesmo após os níveis plasmáticos terem diminuído, favorecendo a teoria do bloqueio da condução nervosa (OLIVEIRA et al, 2010).

Anestésicos locais, como a lidocaína, além do conhecido efeito anestésico local, quando utilizados por em via sistêmica, têm se mostrado eficazes na modulação da cascata inflamatória, em casos de isquemia e reperfusão, em diferentes órgãos, como coração, pulmão e fígado. A administração intraperitoneal da lidocaína se mostrou ainda mais eficaz no controle da inflamação, quando comparada com a administração sistêmica, visto que o alvo de efeitos do fármaco, provavelmente, são as células mesoteliais (LEE et al., 1998; TOMORI et al., 1998; DAS \& MISRA, 2003; VINTEN-JOHANSEN, 2004; PERNIOLA, et al., 2014). 
Além disso, estudos tem demonstrado que os anestésicos locais exercem efeito antiinflamatório, atuando in loco, em vários tipos de células inflamatórias, incluindo monócitos, macrófagos e neutrófilos (HOLLMANN \& DURIEUX, 2000; COHEN, 2002; KAHOKEHR et al., 2011).

Em ensaios clínicos duplo-cego demonstrou-se que o uso intraperitoneal da lidocaína foi superior à infusão intravenosa no controle da dor, com redução no consumo de opioides de até 50\%, em procedimentos cirúrgicos de dor visceral moderada a severa, além de retorno precoce da função gastrointestinal. Embora ainda desconhecido o mecanismo de ação da lidocaína no controle da dor visceral, os resultados indicam que os efeitos da lidocaína são, predominantemente, via receptores intraperitoneais, bloqueando terminações nervosas aferentes peritoneais ou fibras aferentes vagais, que transportam os estímulos sensoriais do intestino e peritônio. Ainda, a absorção sistêmica da lidocaína administrada por via intraperitoneal, também apresentará um efeito sistêmico e em sistema nervoso central (BEAUSSIER, et al., 2007; KAHOKEHR et al., 2011; BERTOGLIO et al. 2012; PERNIOLA et al. 2014).

Além disso, tem-se verificado atividade antimicrobiana dos anestésicos locais, quando testados in vitro contra micro-organismos e in vivo, apresentando redução de mortalidade em roedores com peritonite séptica induzida (NISHINA et al., 1995; AYDIN et al., 2001; BROCCO et al., 2008; CAMARGO et al., 2013).

Sendo assim, a avaliação dos resultados da utilização intraperitoneal da lidocaína, em casos de peritonite séptica, para uso em lavagens peritoneais seriadas, seria inovador.

2.5.2 Combate local à produção de fibrina: heparina

Associadas às soluções poliônicas, inúmeras substâncias tem sido testadas para serem utilizadas durante a lavagem peritoneal. Os fármacos anticoagulantes são utilizados com o objetivo de prevenir a formação de coágulos de fibrina e consequentemente, inibir a formação de aderências. 
A heparina é um proteoglicano ácido sulfatado, com peso molecular variável, que apresenta propriedade anticoagulante e, tem se mostrado eficiente em reduzir a formação de aderências. A heparina age como um cofator de antitrombina III, potencializando sua ação, o que resulta na redução da produção de trombina, responsável pela conversão de fibrinogênio em fibrina, que é um dos componentes iniciais da formação de aderências fibrosas (PALMA et al., 2005; BORGHESAN, 2010). Chalkiadakis et al. (1983) encontraram efeitos benéficos em relação à administração da heparina em ratos, traduzidos pela diminuição de depósitos de fibrina na cavidade peritoneal.

A administração de heparina diluída em solução poliônica, intra-abdominal, durante laparotomias exploratórias, em equinos, tem sido rotineiramente utilizada, embora ainda existam poucos estudos que documentem cientificamente sua eficácia ou mesmo indicação (EGGLESTON \& MUELLER, 2003; BAHADIR et al., 2007; AYSAN et al., 2010; KEMENT et al., 2011).

Em ratos, a utilização da heparina tem sido avaliada, por via parenteral e intraperitoneal, com o intuito de inibir a deposição de fibrina e minimizar a fixação de bactérias, elevando, assim, a eficiência da antibioticoterapia, além de apresentar alguma ação anti-inflamatória relacionada com a inibição da migração leucocitária para o foco inflamatório (PEJLER et al., 1988; ARIMATEIA, 2011).

2.5.3 Combate local às aderências: carboximetilcelulose

Infecções intra-abdominais são acompanhadas por deposição de fibrina na cavidade abdominal. Esse fenômeno pode levar à formação de aderências e abscessos polimicrobianos (CARNEIRO et al. 2002; RODRIGUES et al. 2005)

A carboximetilcelulose é um biopolímero derivado da celulose, de origem vegetal, altamente solúvel em água, e tem sido utilizada no interior da cavidade abdominal de equinos submetidos à laparotomia exploratória, com resultados satisfatórios. O uso experimental da carboximetilcelulose $1 \%$, em solução estéril, na dose de $7 \mathrm{ml} / \mathrm{kg}$, sugere redução e prevenção da formação de aderências, visto que promove uma separação mecânica entre as superfícies peritoneais adjacentes, sendo 
biologicamente compatível e promovendo reduzida irritabilidade ao peritônio (DIZEREGA \& RODGERS 1992; LOPES et al., 1999; FROLLINI, 2009; LEIRA et al., 2012).

Buscando evitar a formação de aderências, soluções de carboximetilcelulose podem ser preparadas, em densidade e viscosidade semelhantes ao líquido sinovial e introduzidas na cavidade abdominal, com intuito de aumentar a viscosidade do meio e evitar atrito entre os segmentos intestinais e órgãos cavitários. Acredita-se que um dos mecanismos de ação da carboximetilcelulose seja por meio da formação de fina membrana viscosa, que funciona como barreira durante o período de regeneração epitelial, prevenindo o contato entre as superfícies serosas das vísceras e do peritônio parietal, dificultando a formação de aderências (LEE et al., 2012). Além disso, a carboximetilcelulose atua reduzindo a atividade fibroblástica e prevenindo a deposição de fibrina nas superfícies serosas (PACHECO et al., 2003; RODRIGUES et al., 2005). Também, por se tratar de uma solução densa, a carboximetilcelulose potencializa o ato de englobar e carrear microorganismos, substâncias pró-inflamatórias e cáusticas para o meio externo durante a lavagem peritoneal (ONCEL et al., 2003; LEE et al., 2012; HA et al., 2016).

Embora, em equinos, sua utilização seja estimulada durante os procedimentos cirúrgicos abdominais, não se tem informações, na literatura consultada, do seu emprego em soluções de lavagem peritoneal, em nenhuma espécie animal.

\subsection{Modelo experimental}

Para que se faça possível o estudo do tratamento da peritonite em equinos com protocolos de lavagem peritoneal seriada, propõe-se utilizar neste trabalho, um modelo experimental que possua em sua fisiologia de trato digestório, aspectos semelhantes à fisiologia do equino. As cobaias (Cavia porcellus), por ser uma espécie monogástrica, herbívora e com ceco desenvolvido, apresentam sistema gastrointestinal susceptível às desordens ocorridas pelas falhas de manejo alimentar, além de maior sensibilidade às fibras de baixa qualidade, apresentando, clinicamente, 
quadros de hipomotilidade, compactações e colite, assim como semelhanças clínicas com a espécie equina quando instalada uma infecção peritoneal (ANDRADE et al., 2002; PEREIRA 2002).

\section{HIPÓTESE}

As lavagens peritoneais com as soluções propostas possuem maior efeito sobre a sobrevida e celularidade peritoneal quando comparado a solução apenas com Ringer lactato.

\section{JUSTIFICATIVA}

Diante do elevado índice de óbito relacionado às complicações referentes à peritonite em equinos e, devido à complexidade de fatores que envolvem a fisiopatologia desta afecção, bem como a reduzida eficácia dos tratamentos existentes, faz-se necessário o estudo de novas terapêuticas, almejando o desenvolvimento de soluções comerciais realmente efetivas, contribuindo de forma inovadora com a clínica de equinos.

\section{OBJETIVOS}

\subsection{Objetivo Geral}

Avaliar comparativamente a eficácia da utilização de diferentes soluções para lavagem peritoneal seriada na redução das aderências abdominais e resposta inflamatória, local e sistêmica, elevando a sobrevida de cobaias com peritonite fecal.

\subsection{Objetivos Específicos}

- Validar um modelo experimental para estudo da peritonite, utilizando-se cobaias, herbívoros monogástricos com ceco funcional, cujos resultados possam ser transpostos para equinos;

- Avaliar e comparar diferentes soluções para lavagem peritoneal seriada no tratamento de peritonite fecal induzida;

- Avaliar e comparar, em relação aos diferentes tratamentos, as lesões em órgãos remotos, como fígado e rins; 
- Avaliar e comparar, em relação aos diferentes tratamentos, as taxas de sobrevida das cobaias com peritonite fecal induzida;

- Propor um novo protocolo de tratamento para peritonite, com eficácia superior aos protocolos existentes.

\section{MATERIAL E MÉTODOS}

\subsection{Animais Experimentais}

No presente estudo foram utilizadas 46 cobaias (Cavia porcellus), adquiridas em criatório comercial. Todas as cobaias tiveram acesso à água limpa e fresca, $380 \mathrm{~g}$ de feno de capim Tifton 85, $7 \mathrm{~g}$ de capim Napier, 20g ração comercial (nutricobaia ${ }^{\circledR}$ - presence) (figura 1), duas vezes ao dia e suplementação de vitamina C (250 mg/kg), por via oral (VO), uma vez ao dia.

Figura 1. Cobaias alojadas em gaiolas individuais com livre acesso a água e forragem
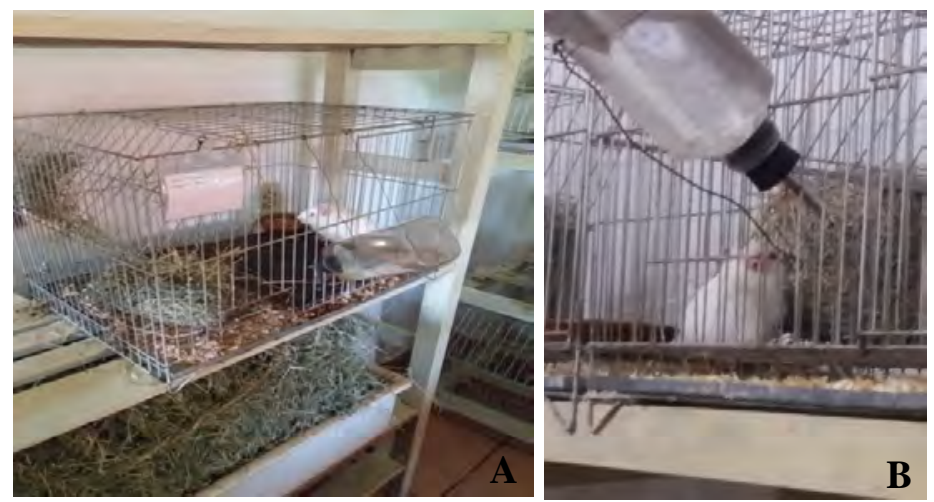

A - Cobaia em gaiola individual, com acesso a água fresca e feno de tifton e comedouro para ração. B Cobaia se ingerindo forragem ofertada.

Todas as cobaias ficaram alocadas em ambiente climatizado $\left(24^{\circ} \pm 1^{\circ}\right)$, com temperatura controlada, alojadas em gaiolas, um indivíduo por gaiola, com $1000 \mathrm{~cm}^{2}$ para cada indivíduo e acesso visual aos outros indivíduos, contando com bebedouros e comedouros individuais, monitorados diuturnamente (figura 2), em tempo real, por meio de câmera de vídeo acompanhada por dispositivos fixos e móveis, 24 horas. 
Figura 2. Monitoramento por vídeo dos animais no biotério, para o acompanhamento remoto da condição dos animais.
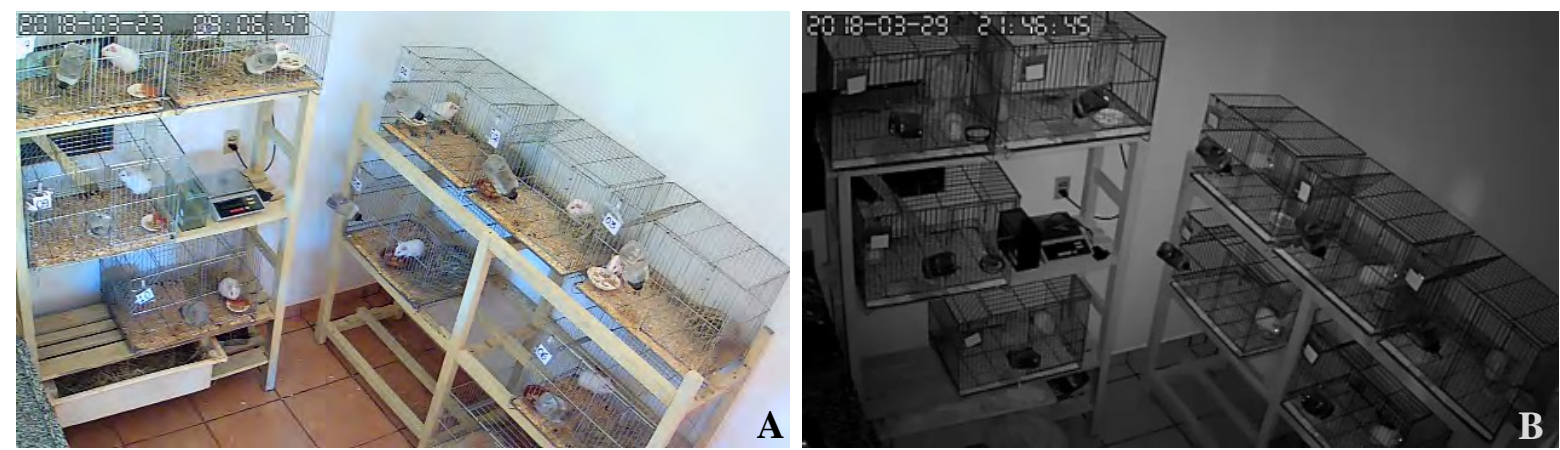

A - Cobaias sendo avaliadas quanto ao comportamento diurno com luz natural. B - Cobaias sendo avaliadas quanto ao comportamento noturno, sem a presença da luz artificial (captação através de infravemelho)

\subsection{Procedimento Experimental}

\subsubsection{Grupos experimentais}

As cobaias foram divididas aleatoriamente em cinco grupos experimentais, sendo um grupo composto por 6 indivíduos (três machos e três fêmeas, com cerca de 8 semanas e peso entre 350 e 650 gramas) para validação do modelo de indução de peritonite fecal $(\mathrm{GM}=6)$, seguindo as técnicas descritas por White II (1990), Torres et al. (1999), Mendes et al. (2000), Brocco et al. (2008) e Camargo et al. (2013) em ratos. Para isso, foi realizada injeção intraperitoneal (IP) de $5 \mathrm{~mL} / \mathrm{kg}$ de uma suspensão composta por fezes autólogas, maceradas e filtradas. A suspensão foi preparada com $2 \mathrm{~g}$ de fezes recém-defecadas dos próprios indivíduos (pesadas em balança eletrônica), diluídas em $17 \mathrm{ml}$ de solução de cloreto de sódio a $0,9 \%$ (solução salina) e filtrada em filtro de papel estéril, retendo o material particulado (figura 3), para que não houvesse interferência na administração, garantindo a livre passagem da solução pela agulha.

Figura 3. Preparo da solução de indução de peritonite com fezes autólogas. 

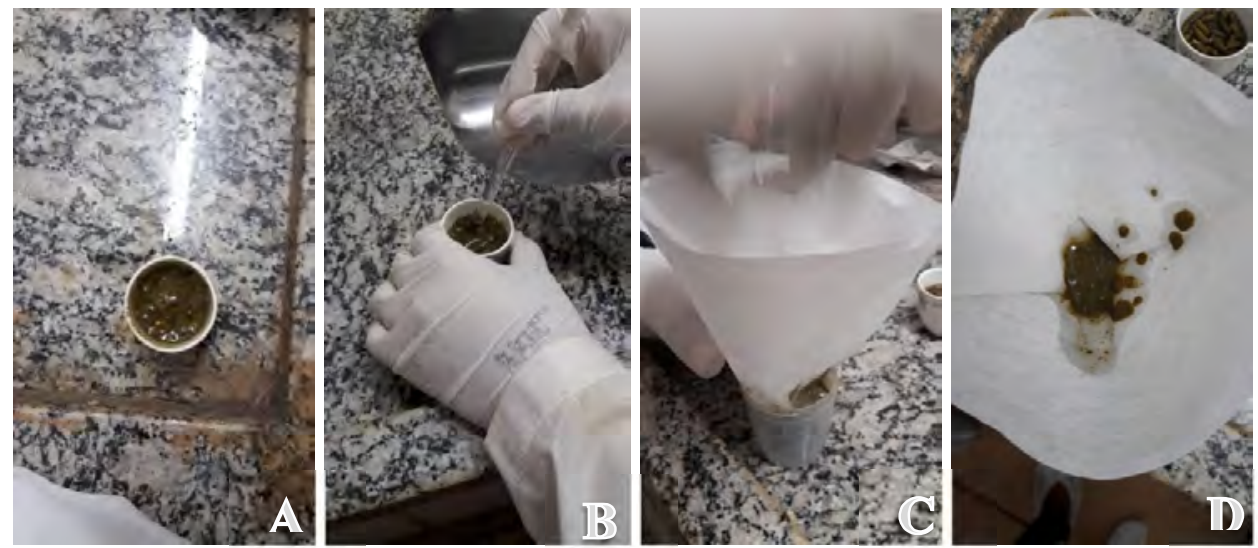

A - Fezes coletadas e diluídas em solução físiológica ( $\mathrm{NaCl} 0,9 \%)$; B - fezes sendo maccradas com auxílio de bastão de vidro; C - Etapa de filtragem por gravidade; D - Material particulado grosseiro retido no filtro, passando para o coletor a fração líquida com material particulado menos grosseiro.

A técnica utilizada em ratos foi seguida para que pudesse avaliar a similaridade do quadro em cobaias. Todos os animais deste grupo vieram a óbito em até 22 horas, visto que não foi encontrado trabalho com desenho semelhante utilizando a espécie deste trabalho (Cavia porcellus), tomou-se por padrão este curso, para animais não tratados. Validado o modelo de indução de peritonite em cobaias, foram iniciados os estudos nos grupos controle e experimentais.

\subsubsection{Indução da peritonite séptica e preparo dos animais para lavagem peritoneal}

Os animais foram anestesiados por meio da administração, por via intramuscular, na face anterior da coxa esquerda, de uma associação de cloridrato de diazepam $(2,5 \mathrm{mg} / \mathrm{kg})$ e cloridrato de cetamina $(50 \mathrm{mg} / \mathrm{kg})$.

Na sequência, foi realizada ampla tricotomia e bloqueio anestésico local, em botão, com 0,2 $\mathrm{mL}$ de lidocaína $2 \%$ (sem vaso constritor) em cada um dos dois pontos de acesso à cavidade, sendo um ponto abdominal ventral e outro paralombar.

A antissepsia local foi realizada com clorexidine degermante e clorexidine alcoólico no local onde seriam implantadas as sondas abdominais e a via por onde foi realizada a indução da peritonite fecal, inoculando $5 \mathrm{~mL} / \mathrm{kg}$ da solução séptica.

Na sequência, os dois acessos à cavidade abdominal foram realizados, sendo fixadas duas sondas uretrais $\mathrm{n}^{\circ} 20$ (encurtadas para três $\mathrm{cm}$ ), as quais foram utilizadas na realização das lavagens 
peritoneais. O primeiro acesso foi realizado na linha média abdominal ventral, próximo à cicatriz umbilical e o segundo acesso na região paralombar lateral esquerda (flanco esquerdo).

Para tanto, foi realizada incisão de pele, seguida de divulsão romba da camada subcutânea e incisão das junções aponeuróticas até incidir o peritônio, quando as sondas uretrais foram introduzidas ao abdômen. As sondas foram fixadas nas junções aponeuróticas, em padrão de sutura Wolf, com fio de náilon, 3-0. O tecido subcutâneo foi aproximado em padrão de sutura Cushing, com fio de poligalactina 910, 2-0 e a pele com padrão simples interrompido, com náilon, 3-0. O curativo foi realizado utilizando gaze não estéril e esparadrapo a fim de proteger as sondas.

Após indução da peritonite fecal e posicionamento das sondas para realização das lavagens peritoneais, os animais foram assistidos durante a recuperação anestésica, sem apresentar complicações.

Quatro grupos foram constituídos por 10 indivíduos, sendo cinco machos e cinco fêmeas, com 8 semanas e peso entre 350 e 600 gramas $(535,0 \pm 45 \mathrm{~g})$. Um grupo foi considerado grupo controle $(\mathrm{GC} ; \mathrm{n}=10)$ e três grupos experimentais (GL, GLH, GLHC; $\mathrm{n}=10)$.

Foi induzida peritonite fecal nos animais do grupo controle e grupos experimentais, sendo que as cobaias do GC foram tratadas com lavagem peritoneal seriada com solução de ringer lactato; as cobaias do Grupo Lidocaína (GL) foram tratadas com lavagem peritoneal seriada com solução de ringer com lactato adicionada de lidocaína $(2,5 \mathrm{mg} / \mathrm{kg})$; as cobaias do Grupo Lidocaína-Heparina (GLH) foram tratadas com lavagem peritoneal seriada utilizando solução de ringer lactato, adicionada de lidocaína $(2,5 \mathrm{mg} / \mathrm{kg}$ ) e heparina (40 UI/kg); e as cobaias do Grupo LidocaínaHepraina-Carboximetilcelulose (GLHC) foram tratadas com lavagem peritoneal seriada com solução de ringer lactato, adicionada de lidocaína $(2,5 \mathrm{mg} / \mathrm{kg})$, heparina (40 UI/ $\mathrm{kg})$ e carboximetilcelulose $(7 \mathrm{ml} / \mathrm{kg}$ ) solução a $1 \%$. Em todos os grupos (GC, GL, GLH e GLHC), as lavagens peritoneais iniciaram seis horas após a indução da peritonite e foram repetidas a cada oito horas, durante sete dias consecutivos, com volume padronizado de $30 \mathrm{~mL}$ por lavagem. 
Todos os animais receberam, sistemicamente, na coxa direita, anti-inflamatório não esteroidal, flunixin meglumine $(2,5 \mathrm{mg} / \mathrm{kg}$ ), por via intramuscular (IM), durante cinco dias e antibioticoterapia, com gentamicina $(3 \mathrm{mg} / \mathrm{kg})$ e ceftiofur $(1 \mathrm{mg} / \mathrm{kg})$, IM, uma vez ao dia, durante sete dias. Caso apresentassem dor não responsiva ao antiinflamatório, ou dor após a suspensão do antiflamatório ( $8^{\circ}$ ao $12^{\circ}$ dia) administrava-se metadona $(3,6 \mathrm{mg} / \mathrm{kg})$, um analgésico opióide, por via subcutânea (SC), a cada 12 horas.

\subsubsection{Lavagem peritoneal}

Após o tempo pré-estabelecido (seis horas) após a indução da peritonite séptica, foram iniciadas as lavagens peritoneais (30 mL por lavagem/animal). Para tanto, as soluções pré-determinadas para cada grupo foram infundidas, pela sonda uretral posicionada na região paralombar esquerda, enquanto que pela sonda uretral posicionada na linha média abdominal ventral, o líquido peritoneal foi drenado, espontaneamente e/ou massageando o abdômen. Quando não houve mais fluxo, a sonda foi ocluída. Nos intervalos entre as lavagens, as sondas permaneceram fechadas e protegidas por curativo.

Para as lavagens peritoneais, os animais foram contidos fisicamente, sendo que o método mais seguro para se conter uma cobaia consiste em colocar uma mão sob o tórax e com a outra apoiar a parte posterior do animal, para suportar o peso do animal, permitindo que ele fique sentado sobre a palma da mão (ANDRADE, 2002).

Após sete dias, foi realizada a retirada das suturas de pele e das sondas. Após bloqueio anestésico local, foi realizada sutura simples interrompida, com náilon 2-0, para ocluir o espaço ocupado pelas sondas na parede abdominal e pele.

\subsubsection{Avaliação clínica comportamental}

Foram mensuradas, a cada 12 horas, ingestão de alimento e água, os animais foram pesados em balança eletrônica, a cada 24 horas, para acompanhamento de peso (figura 4). 
Figura 4. Pesagem diária individual dos animais

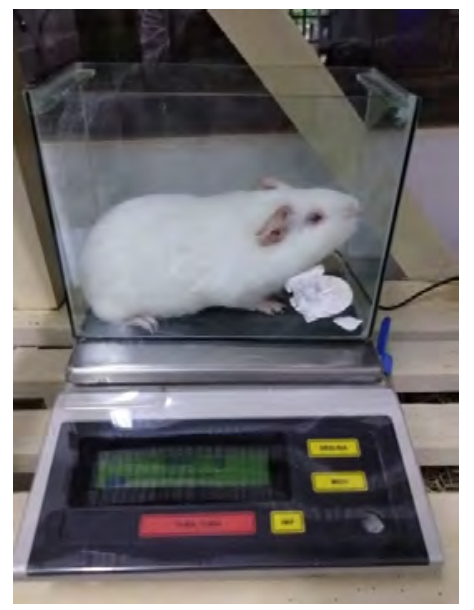

Pesagem diária para acompanhamento da curva de peso dos animais antes e após indução de peritonite séptica.

Ainda para avaliação clínica e comportamental, com a mensuração do padrão de movimentos respiratórios, coloração de mucosa nasal, temperatura corporal, interesse por alimento e ingestão de água, de acordo com o quadro 1.

Quadro 1. Avaliação clínica/comportamental individual.

\begin{tabular}{|l|l|}
\hline Indivíduo (1) & Condição \\
\hline Movimentos respiratórios & Normal ( ) Aumentado ( ) \\
\hline Coloração de mucosa oral & Hipocorada ( ) Normocorada ( ) Hipercorada ( ) \\
\hline Temperatura Retal & \\
\hline Busca por alimento & Presente ( ) Ausente ( ) \\
\hline Ingestão água & Presente ( ) Ausente ( ) \\
\hline
\end{tabular}

Também foi avaliado o comportamento dos animais que indicassem desconforto e ou dor, segundo Patrick \& Villano (2013) adaptado para o comportamento específico de cobaias (Cavia porcellus)(quadro 2).

Quadro 2. Sinais clínicos indicativos de dor em roedores.

\begin{tabular}{|c|c|}
\hline SINAL & DESCRIÇÃO \\
\hline
\end{tabular}




\begin{tabular}{|c|c|}
\hline Aparência Anormal & $\begin{array}{l}\text { Pêlos fora do cuidado natural (pelos bagunçados), } \\
\text { piloereção, cifose vertebral. }\end{array}$ \\
\hline Alteração Comportamental I & $\begin{array}{l}\text { Diminuição do comportamento exploratório, e do } \\
\text { consumo de alimento e ingestão de água. }\end{array}$ \\
\hline Desconforto ao Toque & $\begin{array}{l}\text { Alteração postural, evitando o toque numa } \\
\text { determinada região, seja à manipulação ou toque na } \\
\text { caixa de alojamento. }\end{array}$ \\
\hline Estereotipia Comportamental & $\begin{array}{l}\text { Cuidado excessivo com alguma parte do corpo, } \\
\text { excesso de lambedura, presença de mordida na pele, } \\
\text { coceiras repetitivas sem agente irritante (mutilações } \\
\text { em geral). }\end{array}$ \\
\hline Vocalização & Quando a área de algia é palpada ou manipulada \\
\hline $\begin{array}{c}\text { Alteração do comportamental } \\
\text { II }\end{array}$ & $\begin{array}{l}\text { Cifose vertebral ao caminhar, espasmos e/ou } \\
\text { contrações musculares, letargia e agressividade. }\end{array}$ \\
\hline
\end{tabular}

Fonte: Adaptado de Patrick \& Villano (2013).

Se a dor fosse considerada limitante (RAFEE, et al 2017), o indivíduo seria retirado do experimento, conforme parâmetros propostos na tabela 1, baseando se no comportamento de dor e desconforto em roedores, associado ao comportamento de particular de cobaias (Cavia porcellus).

Quadro 3. Escala de avaliação e mensuração de desconforto e dor para cobaias.

\begin{tabular}{|c|l|}
\hline \multirow{2}{*}{ Aparência } & $\begin{array}{l}\text { Normal 0 } \\
\text { Anormal (pelos bagunçados) } 1 \\
\text { Piloereção 2 }\end{array}$ \\
\hline $\begin{array}{c}\text { Comportamento } \\
\text { exploratório }\end{array}$ & $\begin{array}{l}\text { Normal (exploratório) } 0 \\
\text { Alterado (apático/sem exploração ambiental) } 1 \\
\text { Prostrado (localizado nos cantos somente deitado) } 2\end{array}$ \\
\hline \multirow{2}{*}{ Postura } & $\begin{array}{l}\text { Normal 0 } \\
\text { Defensiva (evita encostar no piso da gaiola) } 1 \\
\text { Alterada (arqueamento de dorso, contração abdominal) } 2\end{array}$ \\
\hline \multirow{2}{*}{ Lambedura } & $\begin{array}{l}\text { Normal (lambedura por todo corpo sem privilegiar uma parte } \\
\text { especifica) } 0 \\
\text { Aumentada (lambedura na região da cirurgia, de forma }\end{array}$ \\
\hline
\end{tabular}




\begin{tabular}{|c|l|}
\hline & $\begin{array}{l}\text { intermitente) 1 } \\
\text { Anormal (lambedura seguida ou não de mordedura intermitente } \\
\text { e frequente de qualquer região do corpo) } 2\end{array}$ \\
\hline $\begin{array}{c}\text { Comportamento } \\
\text { ao manejo }\end{array}$ & $\begin{array}{l}\text { Dócil } 0 \\
\text { Desinteressado (apático) } 1 \\
\text { Agressivo (tentativa de mordedura no manejador) } 2\end{array}$ \\
\hline $\begin{array}{c}\text { Sensibilidade ao } \\
\text { toque das áreas } \\
\text { cirurgiadas }\end{array}$ & $\begin{array}{l}\text { Normal (sem desconforto a palpação) } 0 \\
\text { Aumentada (Contração abdominal ao toque) } 1 \\
\text { Anormal (tentativa de mordedura no manejador ou vocalização } \\
\text { ao toque) } 2\end{array}$ \\
\hline $\begin{array}{c}\text { Comportamento } \\
\text { Alimentar }\end{array}$ & $\begin{array}{l}\text { Normal (se alimentando de todas as fontes oferecidas) } 0 \\
\text { Seletivo (escolhendo determinado alimento em pequenas } \\
\text { porções) 1 } \\
\text { Anormal (anorexia, não buscando alimento) } 2\end{array}$ \\
\hline
\end{tabular}

Os animais foram avaliados, quanto à clínica e comportamento, a cada duas horas nas primeiras 12 horas da indução da peritonite (presencialmente e remotamente); a cada quatro horas nas 24 horas seguintes; e a cada oito horas até que se completem 72 horas. Após 72 horas, os animais foram avaliados a cada 12 horas, durante 12 dias.

\subsubsection{Colheita de sangue e líquido peritoneal}

Foram realizadas colheitas de sangue com acesso pela veia cava, acondicionados em microtubos $(250 \mu \mathrm{L})$ em duplicata, um com EDTA e um com acelerador de coágulo, respeitando o volume máximo de $1 \%$ do volume total da espécie, a cada 24 horas, seguindo desde T0 (antes da indução da peritonite fecal) até o último dia de lavagem peritoneal (T1, T2, T3, T4, T5, T6 e T7), metodologia recomendada no manual de uso de utilização de animais da Fundação Oswaldo Cruz para uso de animais na experimentação animal, para avaliação hematológica e bioquímica.

Foram realizadas colheitas de líquido peritoneal, imediatamente antes da indução da peritonite fecal (T0) e a cada 24 horas, imediatamente antes da lavagem peritoneal, durante sete dias (T1, T2, T3, T4, T5, T6 e T7). Em cada momento eram colhidas duas frações, uma em tubo contendo EDTA $(500 \mu \mathrm{L})$, para avaliação laboratorial e outra em micro tubo criogênico (1 mL), para mensuração de lactato peritoneal. 


\subsubsection{Avaliação laboratorial de sangue e líquido peritoneal}

As amostras de sangue foram analisadas em analisador hematológico BC 2800 VET Myndray® e foi realizada a contagem diferencial e análise morfológica dos leucócitos (exame ao microscópio de esfregaços corados pelo Corante Rosenfeld). Da mesma forma, foram realizadas análises bioquímicas séricas de funções renal e hepática.

Nas amostras de líquido peritoneal, em tubo com EDTA, foram avaliados aspectos físicos, como coloração, aspecto, densidade (refratômetro) e presença de coágulos ou fibrina; exame químico, como pH, sangue oculto, glicose e proteína total (refratômetro); exame citológico, como contagem de hemácias (câmara de Neubauer), contagem global de células nucleadas (Câmara de Neubauer) e contagem diferencial e análise morfológica dos leucócitos (exame ao microscópio de esfregaços corados pelo Corante Rosenfeld). O lactato peritoneal foi dosado pelo método de lactato oxidase em analisador automático.

\subsubsection{Avaliação do fibrinogênio peritoneal}

As amostras de líquido peritoneal, colhidas em micro tubo criogênico, foram congeladas a $-80^{\circ} \mathrm{C}$ para posterior avaliação. A dosagem de fibrinogênio utilizou a técnica de precipitação por aquecimento, ou seja, após mensuração peritoneal das proteínas totais, realizou-se aquecimento da amostra em banho maria a $56^{\circ} \mathrm{C}$, por 5 minutos e nova leitura, sendo a diferença entre as leituras, o valor do fibrinogênio peritoneal.

\subsubsection{Eutanásia}

Ao final de 14 dias, todos os animais foram eutanasiados, de acordo com método descrito e aceito pelo Conselho Nacional de Controle e Experimentação Animal, para avaliação macroscópica das alterações em cavidade abdominal e avaliação histopatológica de fragmentos de tecidos colhidos.

Sendo assim, os animais foram contidos quimicamente com diazepam $(2,5 \mathrm{mg} / \mathrm{kg})$ e cetamina (50 mg/kg), administrados por via intramuscular, seguido de anestesia geral inalatória por 
meio de algodão embebido com isoflurano, em câmara hermeticamente fechada. Uma vez em plano profundo de anestesia (sem reflexo palpebral e com globo ocular rotacionado, mas com batimento cardíaco), os animais receberam cloreto de potássio $(100 \mathrm{mg} / \mathrm{kg})$, por via intra-cardíaca, sendo o óbito confirmado pela avaliação clínica dos batimentos cardíacos (por meio de monitor multiparamétrico e confirmada com avaliação clínica) e pela ausência de resposta ao estímulo palpebral e corneal.

\subsubsection{Avaliação macroscópica das alterações abdominais}

Após eutanásia, foi realizada incisão em forma de ferradura ou U invertido, na cavidade abdominal e assim avaliadas macroscopicamente, possíveis alterações em órgãos abdominais, formações de aderências e focos de infecção. As aderências classificadas em seis graus, segundo adaptação de Diogo-Filho et al. (2004) (Tabela 1).

Tabela 1. Avaliação do grau de aderência na cavidade abdominal.

\begin{tabular}{|l|l|}
\hline \multicolumn{1}{|c|}{ GRAU } & \multicolumn{1}{c|}{ ACHADO MACROSCÓPICO } \\
\hline $\mathbf{0}$ & $\begin{array}{l}\text { Ausência de aderências } \\
\text { aderir segmentos ou facilmente desfeitas pela manipulação }\end{array}$ \\
\hline $\mathbf{2}$ & $\begin{array}{l}\text { Aderências firmes resistentes a manipulação, entre alças, não } \\
\text { envolvendo a parede abdominal }\end{array}$ \\
\hline $\mathbf{3}$ & $\begin{array}{l}\text { Aderências firmes, resistentes a manipulação, entre a parede } \\
\text { abdominal e apenas um órgão }\end{array}$ \\
\hline $\mathbf{4}$ & $\begin{array}{l}\text { Aderências firmes, resistentes à manipulação entre parede } \\
\text { abdominal e mais de um órgão. }\end{array}$ \\
\hline $\mathbf{5}$ & $\begin{array}{l}\text { Aderências firmes, resistentes à manipulação entre as alças e } \\
\text { alças e parede abdominal com fistula entérica. }\end{array}$ \\
\hline
\end{tabular}

Fonte: Adaptado de Diogo-Filho et al. (2004) 


\subsubsection{Avaliação microscópica de rim e fígado}

Foram colhidas amostras de fígado e rins direitos, as quais foram fixadas em formol tamponado a 10\%, por 48 horas. Em seguida, as amostras foram desidratadas por meio de banhos em álcool, com concentrações crescentes de etanol 70\%, até chegar ao etanol 100\%. Na sequência, as amostras passaram pelo processo de diafanização, para substituir o etanol, na amostra, por xilol e impregnação, onde o xilol é substituído por parafina fundida a $60^{\circ} \mathrm{C}$, em pequenos blocos, em estufa, promovendo a substituição do xilol pela parafina. Os blocos de parafina foram cortados em micrótomo, ajustado para $3 \mu \mathrm{m}$ de espessura. As lâminas histológicas foram preparadas de tal maneira que pudessem observar os cortes transversais dos tecidos e coradas pela técnica da hematoxilina-eosina (H.E), para posterior análise morfológica ao microscópio de luz.

A avaliação histopatológica foi realizada, buscando avaliar morfologia e possíveis anormalidades, como lesões focais, degenerações, acúmulos intracelulares, esteatoses hepáticas, infiltrado intersticial difuso, edema, membrana basal desnuda na região cortical, células tubulares achatadas com possível dilatação luminal, apoptoses ou lesões necróticas.

Para categorizar os achados em tecido hepático e renal foram atribuídas 4 notas, sendo 0 para a ausência de achados, 1 para presença discreta, 2 para presença moderada, digna de nota, mas de pequena proporção para a disfunção do órgão e 3 para a presença intensa, com indício de lesão no órgão.

\subsection{Análise estatística}

Os dados obtidos na fase experimental foram avaliados nos diferentes tempos e apresentados de maneira descritiva, por meio de texto, tabelas e figuras, descrevendo-se as variáveis qualitativas e quantitativas, em forma de frequências (absolutas e relativas) e percentuais de animais que apresentavam determinada característica, em determinado tempo, para cada item avaliado nos grupos experimentais. Os dados paramétricos foram submetidos à análise estatística empregando-se o software Prism®. Foi utilizada análise de variância para repetições múltiplas (ANOVA) na 
avaliação das diferenças das médias ao longo do tempo dentro de cada grupo e entre os grupos, seguida pelo teste de Tukey e as diferenças consideradas estatisticamente significativas quando $\mathrm{p} \leq 0,05$.

\section{Resultados}

7.1. Acessos cirúrgicos e padronização de volume utilizado

Foram padronizados os acessos cirúrgicos em cobaias para realização de lavagem peritoneal. Verificou-se que o primeiro acesso deveria estar localizado na fossa paralombar esquerda, associado a um túnel subcutâneo dorsal, paralelo às escápulas, visando proteger a sonda, uma vez que o animal experimental é um roedor. O segundo acesso deveria ser paramediano, retro umbilical, ponto este de melhor drenagem, associado a túnel subcutâneo perineal, lateralizado à direita, visando proteger a sonda, respeitando um espaço de $2 \mathrm{~cm}$ da região anal. Com este posicionamento, respeitou-se a anatomia e evitou-se que os animais defecassem ou urinassem nas sondas ventrais (figura 5).

Figura 5. Acessos de localização das sondas.
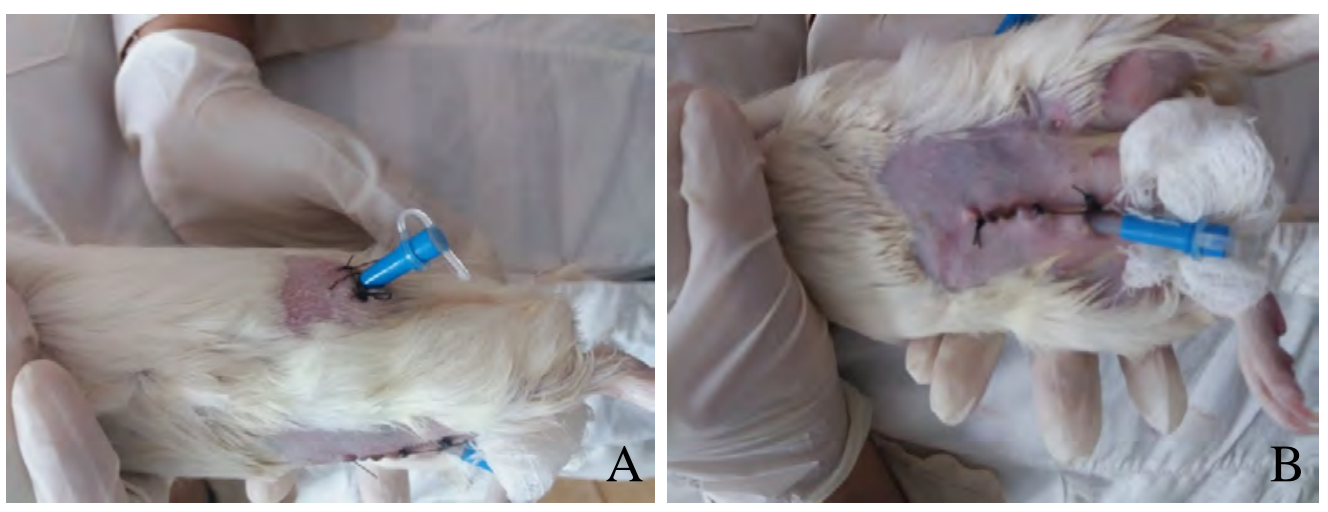

A- sonda em acesso paralombar devidamente fixada após cirurgia. B - Sonda em acesso ventral/abdominal, devidamente fixada posicionada levemente lateralizada para evitar a linha dos genitais.

7.1.1. Tempo de procedimento cirúrgico e recuperação anestésica

Para a implantação das duas sondas abdominais e indução da peritonite fecal foram utilizados $18 \pm 4$ minutos e verificou-se a recuperação anestésica em $96 \pm 10$ minutos. Durante o 
procedimento cirúrgico, a temperatura corporal dos animais atingiu, em média, $36,1^{\circ} \pm 0,2^{\circ} \mathrm{C}$. Após a recuperação anestésica, a temperatura corpórea média foi de $37,6^{\circ} \pm 0,1^{\circ} \mathrm{C}$, quando os animais retornaram à posição quadrupedal, apresentavam redução expressiva no padrão exploratório, sem haver busca por alimento ou água; demonstravam apatia, porém, havia comportamento de fuga nas primeiras 6 horas. Após a sexta hora, os animais apresentavam apatia severa, demonstrada pela redução do comportamento exploratório, sem busca por alimento concentrado e sem vocalização de comunicação entre os animais, mucosas hiperêmicas e hipertermia $\left(39,3 \pm 0,1^{\circ} \mathrm{C}\right)$. Não se verificou dor ao toque na região abdominal (expressado por vocalização ou contração), padrão que permaneceu até durante toda etapa experimental todos os grupos.

7.2. Avaliação in vivo dos tratamentos com lavagem peritoneal utilizando lidocaína, heparina e carboximetilcelulose.

\subsubsection{Avaliação clínico comportamental}

$\mathrm{Na}$ avaliação clínica comportamental, a partir da oitava hora, os animais do GM apresentavam padrão respiratório aumentado (evidenciado pela expansão torácica), mucosas hiperêmicas a cianóticas, apatia intensa, evidenciada pela cessão do comportamento exploratório e imobilidade quando contido, sem ingestão de alimento ou água, apresentando piloereção, porém sem dor ao toque ou qualquer estereotipia comportamental. Neste ponto, os animais apresentavam elevada temperatura corpórea, com média de $39,3^{\circ} \pm 0,3^{\circ} \mathrm{C}$, sendo o basal dos animais $38^{\circ} \pm 0,5^{\circ} \mathrm{C}$. Sem receber qualquer tratamento abdominal, os animais foram eutanasiados quando não existia resposta aos estímulos ambientais, somado ao quadro sistêmico, de hipertermia sem respostas à medicação e mucosas cianóticas. O primeiro animal deste grupo veio a óbito 12 horas após a indução da peritonite fecal e o último, 22 horas após a indução da peritonite fecal, apresentando

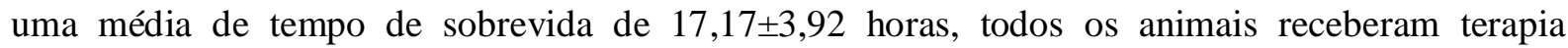
sistêmica. 
No GC, em que foi realizada lavagem peritoneal, três vezes ao dia, com solução de ringer lactato, a média de sobrevida foi de 104 \pm 192 horas. Estes animais demonstraram menor debilidade, reduzindo a necessidade de eutanásia nas primeiras 24 horas. Na avaliação clínica comportamental, a partir da quarta hora, os animais apresentavam padrão respiratório aumentado (evidenciado pela expansão torácica), mucosas hiperêmicas a cianóticas, apatia moderada evidenciada pela redução no comportamento exploratório e imobilidade quando contido, sem ingestão de alimento ou água, apresentando piloereção, porém, sem dor ao toque ou qualquer estereotipia comportamental. Neste ponto, os animais possuíam elevada temperatura corpórea, com média de $39^{\circ} \pm 0,1^{\circ} \mathrm{C}$, sendo o basal de $38^{\circ} \pm 0,5^{\circ} \mathrm{C}$. Este quadro foi alterado, a partir da vigésima sexta hora, quando houve a mudança da coloração das mucosas para cianótica e queda na temperatura corpórea para $38,7^{\circ} \pm 0,1$. Nova alteração aconteceu nos animais que sobreviveram após 72 horas. Houve a melhora da coloração das mucosas, retornando à coloração hiperêmica a rosada, redução da piloereção à pelos bagunçados. Neste grupo, dois animais que sobreviveram, a partir da $72^{\mathrm{a}}$ hora, apresentavam mucosas hiperêmicas e retorno à condição de alimentação e ingestão de água. O comportamento exploratório foi retomado a partir do $4^{\circ}$ dia. Verificou-se que os animais que resistiram a mais ciclos de lavagens, apresentaram quadros de desconforto reduzido, retornando à alimentação e ingestão de água em pequenas quantidades. Sendo assim, $20 \%$ dos animais $(n=2)$ sobreviveram por 12 dias (288 horas), porém $80 \%$ dos animais foram a óbito $(\mathrm{n}=8)$, sendo o primeiro após 32 horas e o último após 3 dias (72 horas).

No GL, em que foi realizada lavagem peritoneal contendo solução de ringer com lactato e lidocaína (GL), três vezes ao dia, a sobrevida média foi de $266,4 \pm 68,3$ horas. Verificou-se que os animais deste grupo apresentaram debilidade mais evidente nas primeiras 48 horas. Após este período, as respostas clínicas passaram a ser positivas, com recuperação dos parâmetros clínicos e retorno da ingestão de alimentação volumosa e concentrada, além da ingestão de água. A partir das 72 horas, o consumo de alimento e água retornou às quantidades semelhantes ao basal. $90 \%$ dos 
animais sobreviveram (n=9) por 12 dias (288 horas). Um animal (10\%) veio a óbito após 3 dias (72 horas). Na avaliação clínico comportamental foi observado um padrão de movimentos respiratórios semelhante ao grupo anterior, onde a partir da quarta hora os animais apresentavam elevação da movimentação respiratória, elevação da temperatura corporal média $\left(39,1 \pm 1^{\circ} \mathrm{C}\right)$, mucosas hiperêmicas a cianóticas e piloereção, com apatia, sem explorar o ambiente. Este padrão se manteve até a $24^{a}$ hora. A partir deste momento, os animais reduziram a expansão torácica durante o movimento respiratório, porém ainda visível (normal para espécie é não ser visível). A partir da $30^{\text {a }}$ hora, os animais apresentavam mucosas hiperêmicas, resposta ao contato quando contido pelo operador, sem dor ao toque ou qualquer estereotipia comportamental quando realizado o curativo. Neste ponto, os animais apresentaram uma temperatura corporal média de $38,8 \pm 1^{\circ} \mathrm{C}$, demonstrando uma resposta clínica no combate da inflamação. À $48^{a}$ hora, os animais começaram a responder positivamente, elevando seu consumo de água e forragem, demonstrando uma reabilitação do quadro de apatia profunda. Alteração mais contundente ocorreu em média a partir da $70^{\mathrm{a}}$ hora, onde os animais passaram a apresentar mucosas levemente hiperêmicas a róseas, sem expansão torácica evidente. Os animais apresentavam comportamento de buscar cuidar do pelo, ainda pelos bagunçados e temperatura média corporal de $38,7 \pm 2^{\circ} \mathrm{C}$. Os animais seguiram gradativamente recuperando a ingestão de água e alimento, bem como o comportamento exploratório nas duas horas seguintes. A partir deste momento, os animais retornaram ao comportamento de se assearem e manterem os pelos arrumados, temperatura corpórea em $37,8 \pm 1^{\circ} \mathrm{C}$.

No GLH, em que foi realizada lavagem peritoneal contendo solução de ringer com lactato, associado à lidocaína e heparina, três vezes ao dia, a sobrevida média foi de $266,2 \pm 68,9$ horas. Os animais evidenciaram conforto e retorno à alimentação com 48 horas, retornando à alimentação volumosa e concentrada e ingestão de água semelhante ao consumo normal. $90 \%$ dos animais sobreviveram por 12 dias (288 horas). Um animal (10\%) foi a óbito com 70 horas, embora estivesse se alimentando e ingerindo água. Semelhante aos grupos anteriores, a partir da quarta hora foi 
observado um padrão de movimentos respiratórios elevados, com elevação da temperatura corporal média $\left(39,1 \pm 1^{\circ} \mathrm{C}\right)$, mucosas hiperêmicas a cianóticas e piloereção, com apatia intensa sem explorar o ambiente, sem comportamento de fuga ou resposta a contenção. Este padrão se manteve até a $24^{a}$ hora. A partir deste momento, os animais reduziram a expansão torácica, porém ainda visível. A partir da $34^{\mathrm{a}}$ hora, os animais apresentavam mucosas hiperêmicas, resposta positiva ao contato quando contido pelo operador, sem dor ao toque ou qualquer estereotipia comportamental quando realizado o curativo. Neste ponto, os animais apresentaram uma temperatura corporal média de $38,7 \pm 2^{\circ} \mathrm{C}$, demonstrando uma boa resposta clínica no combate da inflamação. Assim, houve a manutenção deste quadro até que se completassem 70 horas. Alteração mais contundente ocorreu, em média, a partir da $70^{\text {a }}$ hora, onde os animais passaram a apresentar mucosas róseas, sem expansão torácica evidente. Os animais apresentavam comportamento de buscar cuidar do pelo, ainda pelos bagunçados e temperatura média corporal de $37,8 \pm 1^{\circ} \mathrm{C}$. Os animais seguiram gradativamente recuperando a ingestão de água e alimento, bem como o comportamento exploratório nas quatro horas seguintes. A partir deste momento, os animais retornaram ao comportamento de se assearem e manterem os pelos arrumados.

No GLHC, em que foi realizada lavagem peritoneal contendo solução de ringer com lactato, associado à lidocaína, heparina e carboximetilcelulose, três vezes ao dia, a sobrevida média foi de 250,2 $\pm 5,9$ horas. Os animais demonstraram retorno à condição de conforto e retorno à alimentação com 68 horas. Neste grupo, $80 \%$ dos animais $(\mathrm{n}=8)$ sobreviveram 12 dias (288 horas), sendo que 2 animais vieram a óbito com 70 e 128 horas, embora estivessem comendo e ingerindo água. Na avaliação clínica comportamental, foi observado um padrão de movimentos respiratórios semelhante ao grupo anterior, onde a partir da quarta hora os animais apresentavam elevação da movimentação respiratória, elevação da temperatura corporal média $\left(39,1 \pm 2^{\circ} \mathrm{C}\right)$, mucosas hiperêmicas a cianóticas e piloereção, com apatia sem explorar o ambiente. Este padrão se manteve até a $16^{\mathrm{a}}$ hora e, então, reduziram a expansão torácica, porém ainda visível. A partir da $36^{\mathrm{a}}$ hora, os 
animais apresentavam melhorias nas mucosas, passando de levemente cianótica para hiperêmicas, com resposta ao contato quando contido pelo operador, sem dor ao toque ou qualquer estereotipia comportamental quando realizado o curativo. Neste ponto, os animais apresentaram uma temperatura corporal média de $38,8 \pm 1^{\circ} \mathrm{C}$, demonstrando uma resposta clínica no combate da inflamação. Assim, houve a manutenção deste quadro até as primeiras 48 horas. Alteração mais contundente ocorreu em média a partir da $70^{\mathrm{a}}$ hora, onde os animais passaram a apresentar mucosas róseas, sem expansão torácica evidente. Os animais apresentavam comportamento de buscar cuidar do pelo, ainda pelos bagunçados e temperatura média corporal de $38,8 \pm 1^{\circ} \mathrm{C}$. Os animais seguiram gradativamente recuperando a ingestão de água e alimento bem como o comportamento exploratório nas duas horas seguintes. A partir deste momento, os animais retornaram ao comportamento de se assearem e manterem os pelos arrumados. A temperatura corporal média só foi reestabelecida ao passar das 106 horas, apresentando valor médio de $38,3 \pm 2{ }^{\circ} \mathrm{C}$. Neste parâmetro, somente houve a queda na temperatura $(\mathrm{p}>0,05)$ a partir do $9^{\circ}$ dia, apresentando valores de $37,9 \pm 1^{\circ} \mathrm{C}$

Verificou-se que os animais que vieram a óbito nos grupos GL, GLH e GLHC desequilibraram, em relação ao quadro clínico, bruscamente, apresentando apatia severa sem resposta as medicações durante, após 2 horas até vinham a óbito.

É possível demonstrar a significância $\mathrm{P}>0,05$ quando analisados os grupos GM (0\% de sobrevida) e GC (20\% de sobrevida) em relação aos tratamentos GL (90\% de sobrevida), GLH (90\% de sobrevida) e GLHC (80\% de sobrevida). É necessário ressaltar que apesar de não haver significância $(\mathrm{P}<0,05)$ na sobrevida em horas entre os grupos GL, GLH e GLHC, este último demonstrou o dobro de óbitos (dois óbitos - $80 \%$ de sobrevida), em comparação com os outros dois grupos tratados (GL e GLH) que apresentaram um óbito (90\% de sobrevida), como demonstrado na figura 6.

Figura 6 Sobrevida em horas dos animais entre grupos. 


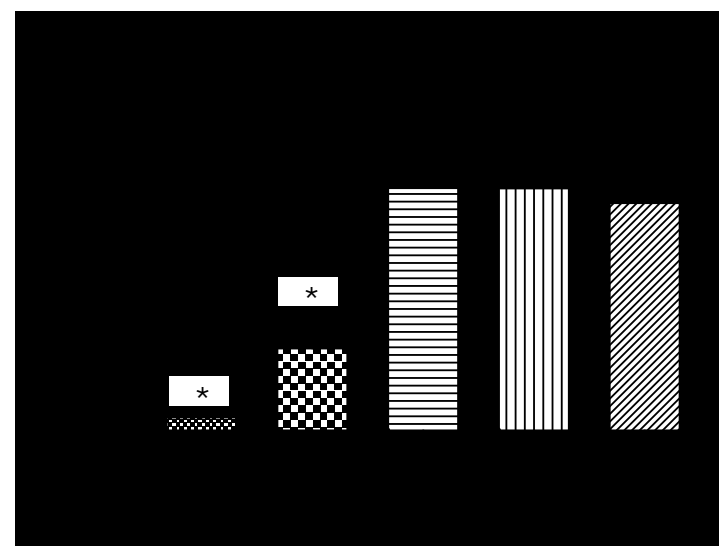

*Variação $(\mathrm{P}>0,05)$ entre os grupos ao longo dos tempos experimentais.

7.2.2. Avaliação da dinâmica do consumo de alimento, água e peso entre os tratamentos

Nos primeiros dois (dos 7) dias da fase de adaptação, os animais consumiam $20 \mathrm{~g} / \mathrm{dia}$ de ração concentrada* Consumiam, em média, $30 \mathrm{~g} \pm 5$ de feno de capim Tifton, não havia consumo de capim Napier e ingeriam, em média, $280 \mathrm{~mL} \pm 30 \mathrm{~mL}$ de água. Após o terceiro dia até o dia da indução da peritonite, o consumo de forragem elevou-se para, em média, $267 \pm 26 \mathrm{~g}$ para feno de capim Tifton, $7 \mathrm{~g}$ de capim Napier, média de $20 \mathrm{~g}$ de ração comercial e consumo médio de água de 230 $\pm 30 \mathrm{~mL}$. As médias de peso se encontravam em $385 \pm 15 \mathrm{~g}$.

Para todos os grupos experimentais, após a indução da peritonite, o consumo tanto de alimentos, quanto de água foram alterados. Nas primeiras oito horas, a média de consumo de ração comercial passou a $1 \pm 1 \mathrm{~g}$, sem consumo de forragem. A ingestão média de água foi de $20 \pm 10 \mathrm{~mL}$. Após a oitava hora, todos os animais receberam $10 \mathrm{~mL}$ de Ringer com lactato pela via subcutânea (SC), como suporte imediato.

Os animais do grupo modelo de indução (GM) sobreviveram por menos tempo, assim não houve reversão do quadro de anorexia, demonstrando peso médio de $404 \pm 19,9 \mathrm{~g}$, ao final de 17,17 $\pm 3,92$ horas. Neste grupo, o peso médio antes da indução era de 450,2 $\pm 20,4 \mathrm{~g}$. 
No grupo controle (GC), nas primeiras oito horas após indução os animais cessaram a ingestão de água, (tabela 3), há consumo significativo apenas em T12h , mantendo sem alteração significativa até o T72h, somente em T120h há novo incremento significativo, seguido de T168h quando o valor é equiparado a T0. Em relação ao consumo de alimento, para o consumo de ração comercial a dinâmica foi semelhante (tabela 4) os animais cessaram a ingestão até T8h, sendo encontrado consumo significativo apenas em T12h, apenas em T120h há alteração significativa no consumo e nova alteração significativa em T168h, quando há semelhança com os valores de T0. Quando se refere ao consumo de forragem (feno de tifton) até T72h não há consumo significativo, apenas em T120 esse consumo é significativo, elevação (p>0,05) ocorre novamente em T168h quando os valores atingem o máximo para o grupo e seguem desta forma até o último dia experimental. Quanto ao consumo de forragem verde o grupo demonstra consumo significativo apenas em T120, mantendo se sem alteração significativa até o final do experimento. Para este

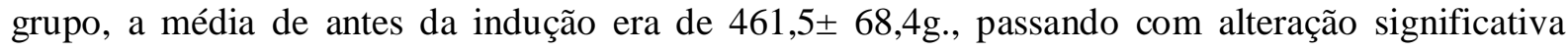

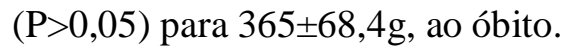

No grupo lidocaína (GL), nas primeiras oito horas após indução os animais cessaram a ingestão de água, (tabela 3), há consumo significativo apenas em T12h, nova alteração ocorre em T48h quando o consumo dobra, assim somente em T120 há alteração significativa passando a

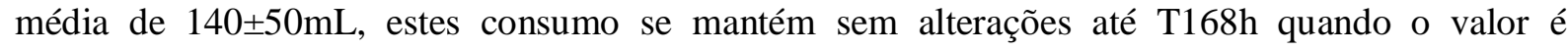
equiparado a T0 com média de $220 \pm 50 \mathrm{~mL}$. Em relação ao consumo de alimento, no consumo de ração comercial a dinâmica foi semelhante (tabela 4) os animais cessaram a ingestão até T8h, sendo

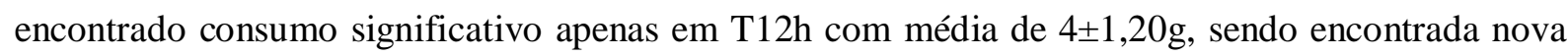

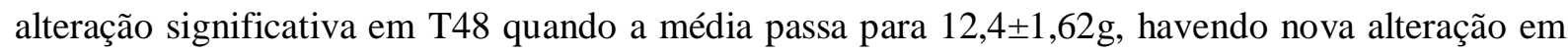
T72 onde os animais do grupo passam apenas em valores semelhantes a T0, seguindo sem alteração significativa nos tempos posteriores. Quando se refere ao consumo de forragem (feno de tifton) o

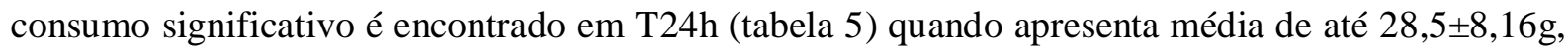


seguindo com elevação significativa em T72h quando demonstra média de consumo em

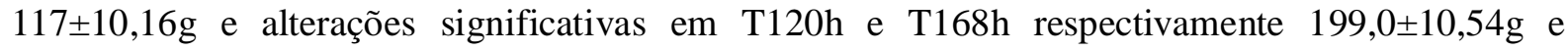
261士10,31g equiparando-se a T0 neste último tempo, seguiu sem alteração significativa até o final do experimento. Quanto ao consumo de forragem verde (tabela 6) o grupo demonstra alteração significativa apenas em T72 com média de $3 \pm 1,2 \mathrm{~g}$, os valores passam a apresentar valores significativos apenas em T120h quando a média demonstrada era de 5,5 $\pm 1,1 \mathrm{~g}$ e em T168h os valores demonstram alteração $(\mathrm{P}>0,05)$ para $7 \pm 0 \mathrm{~g}$, quando havia novamente o consumo total semelhante a T0, mantendo se sem alteração significativa até o final do experimento. Para este

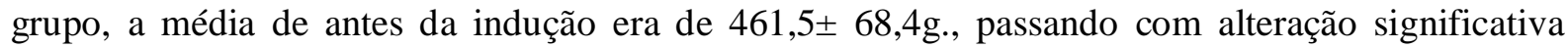

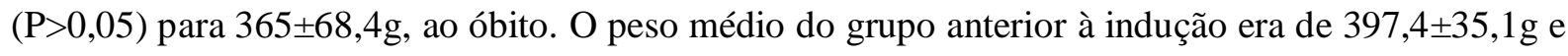
o peso médio ao óbito foi de $409,7 \pm 42,7$.

No grupo lidocaína e heparina $(\mathrm{GLH})$, nas oito horas iniciais após indução os animais cessaram a ingestão de água, (tabela 3), havendo consumo significativo apenas em T12h com média de $40 \pm 10 \mathrm{~mL}$, nova alteração significativa ocorre em T72h quando a média passa a $70 \pm 10 \mathrm{~mL}$ e

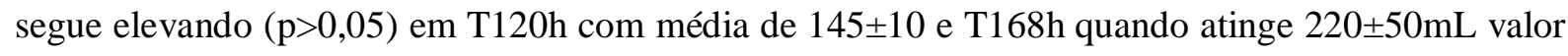
semelhante a média em T0 quando o consumo médio era de $230 \pm 5 \mathrm{~mL}$. Em relação ao consumo de alimento, para a ração comercial a dinâmica foi semelhante (tabela 4) os animais cessaram a ingestão demonstrada em T8h, sendo encontrado consumo significativo apenas em T12h com média

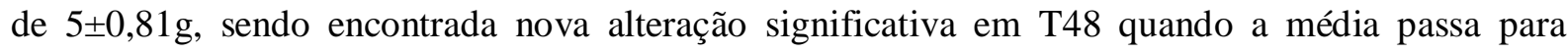

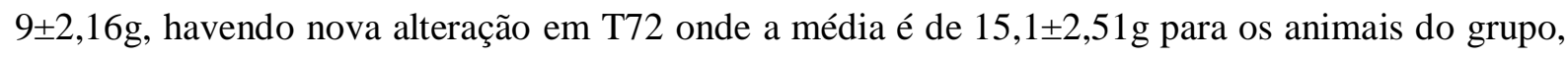
em T120 o grupo demonstra elevação significativa $20 \pm 0,54 \mathrm{~g}$ onde já demonstra valores semelhantes a T0, seguindo sem alteração significativa nos tempos posteriores. Quando se refere ao consumo de forragem (feno de tifton) o consumo significativo é encontrado em T24h (tabela 5) quando apresenta média de até $28,7 \pm 12,31 \mathrm{~g}$, com nova elevação significativa em T48h quando

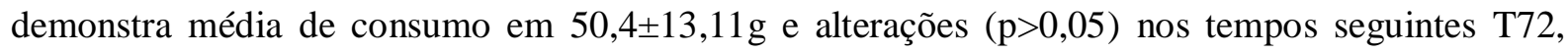


T120 e T168 com médias de 106,8 $\pm 10,31 \mathrm{~g}, 197,8 \pm 10,32 \mathrm{~g}$ e 260,8 $\pm 10,33$ respectivamente, equiparando em T120h os valores encontrados em T0. Quanto ao consumo de forragem verde (tabela 6) o grupo demonstra alteração significativa apenas em T72 com média de $3 \pm 1,4 \mathrm{~g}$, os valores passam a apresentar valores significativos apenas em T120h quando a média demonstrada era de $5,5 \pm 1,1 \mathrm{~g}$ e em T168h os valores demonstram alteração $(\mathrm{P}>0,05)$ para $7 \pm 0 \mathrm{~g}$, semelhante ao demonstrado no GL, quando havia consumo semelhante a T0, mantendo se sem alteração significativa até o final do experimento. Para este grupo, a média de peso antes da indução era de

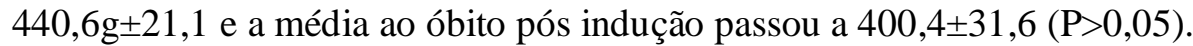

No grupo lidocaína, heparina e carboximetilcelulose (GLHC), até as oito horas iniciais após indução os animais cessaram a ingestão de água, (tabela 3), havendo consumo significativo apenas em T12h com média de 35 $110 \mathrm{~mL}$, nova alteração significativa ocorre em T72h quando a média passa a $70 \pm 10 \mathrm{~mL}$, com nova elevação $(\mathrm{p}>0,05)$ em T120h com média de $140 \pm 10$, em T168h atinge $220 \pm 50 \mathrm{~mL}(\mathrm{p}>0,05)$ valor semelhante a média em T0 quando o consumo médio era de $230 \pm 5 \mathrm{~mL}$. Em relação ao consumo de alimento, para a ração comercial a dinâmica foi semelhante (tabela 4) os animais cessaram a ingestão demonstrada em T8h, sendo encontrado consumo significativo apenas

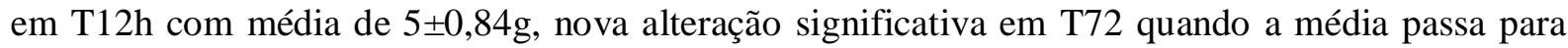
$16 \pm 2,16 \mathrm{~g}$, havendo nova alteração $(\mathrm{p}>0,05)$ em T120 onde a média é de $20 \pm 0,98 \mathrm{~g}$ valor este semelhante aos valores encontrados em T0, o grupo segue sem alteração significativa nos tempos posteriores. Quando se refere ao consumo de forragem (feno de tifton) o consumo significativo é

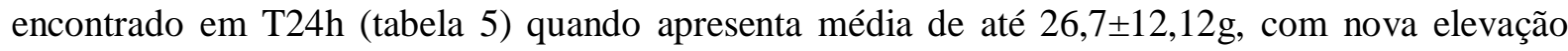
significativa em T72h quando demonstra média de consumo em 100,8 $\pm 10,33 \mathrm{~g}$ e alterações $(\mathrm{p}>0,05)$ nos tempos seguintes, T120 e T168 com médias de 185,8 $\pm 10,39 \mathrm{~g}$ e $263,1 \pm 10,18$ respectivamente, equiparando em T168h com os valores encontrados em T0. Quanto ao consumo de forragem verde

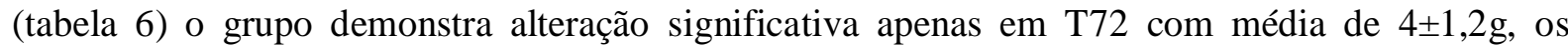
valores alteram-se significativamente apenas em T168h quando a média demonstrada era de 7£0g, 
semelhante ao demonstrado aos grupos de tratamento (GL e GLH), retornando a valores semelhantes a T0, mantendo se sem alteração significativa até o final do experimento. O peso antes

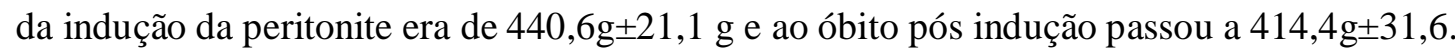

Quando avaliado entre os grupo é possível demonstrar alterações significativas entre o GC e os demais grupos experimentais (GL, GLH e GLHC) nos tempos que vão de T12h a T120h em T168h para as variáveis de consumo de água e ração comercial não há diferença significativa, sendo que para o consumo de forragens há diferença $(\mathrm{P}>0,05)$ quando comparados também em T168. Quando comparados entre os grupos experimentais GL e GLH demonstram valores significativos em relação a GLHC para ingestão de água em T12h e T48h, nas demais variáveis não foi possível observar alteração significativa.

Tabela 2. Valores médios e desvio padrão da ingestão de água $(\mathrm{mL})$ entre os grupos ao longo do período de tratamento.

\begin{tabular}{llllllll}
\hline & T0 & T8h & T12h & T48h & T72h & T120h & T168h \\
GC & $235 \pm 5$ & S.C. & $10 \pm 10^{\#}$ & $10 \pm 50$ & $10 \pm 50$ & $80 \pm 40^{\#}$ & $200 \pm 50$ \\
GL & $235 \pm 5$ & S.C. & $40 \pm 10^{\# *}$ & $80 \pm 10^{\# *}$ & $80 \pm 10^{\#}$ & $140 \pm 50^{\#}$ & $220 \pm 50^{\#}$ \\
GLH & $230 \pm 5$ & S.C. & $45 \pm 10^{\# *}$ & $60 \pm 15$ & $70 \pm 10$ & $145 \pm 10^{\#}$ & $220 \pm 50^{\#}$ \\
GLHC & $230 \pm 5$ & S.C. & $35 \pm 10^{\#}$ & $55 \pm 10$ & $70 \pm 10$ & $140 \pm 10^{\#}$ & $230 \pm 10^{\#}$ \\
\hline
\end{tabular}

${ }^{\#}$ Variação $(\mathrm{P}>0,05)$ dentro do grupo ao longo dos tempos experimentais; *Variação $(\mathrm{P}>0,05)$ entre os grupos ao longo dos tempos experimentais. S.C $=$ Sem consumo.

Tabela 3. Valores médios e desvio padrão do consumo de ração $(\mathrm{g})$ entre os grupos ao longo do período de tratamento.

\begin{tabular}{ccccccccc}
\hline & T0 & T8h & T12h & T24h & T48h & T72h & T120h & T168h \\
GC & $20 \pm 0$ & S.C. & $4 \pm 2,20^{\#}$ & $4 \pm 2,18$ & $2,8 \pm 2,10^{*}$ & $4 \pm 1,48$ & $10 \pm 1,21$ & $20 \pm 0,6$ \\
GL & $20 \pm 0$ & S.C. & $4 \pm 1,20^{\#}$ & $6 \pm 1,32$ & $11,4 \pm 1,62^{\# *}$ & $18 \pm 2,23^{\#}$ & $20 \pm 0,49$ & $20 \pm 0,1$ \\
GLH & $20 \pm 0$ & S.C. & $5 \pm 0,81^{\#}$ & $6 \pm 1,89$ & $9 \pm 2,16$ & $15,1 \pm 2,51^{\#}$ & $20 \pm 0,54^{\#}$ & $20 \pm 0,1$ \\
GLHC & $20 \pm 0$ & S.C. & $5 \pm 0,84^{\#}$ & $4 \pm 1,31$ & $7 \pm 1,81^{\#}$ & $16 \pm 1,33$ & $20 \pm 0,98^{\#}$ & $20 \pm 0,1$ \\
\hline
\end{tabular}


${ }^{\#}$ Variação $(\mathrm{P}>0,05)$ dentro do grupo ao longo dos tempos experimentais; *Variação $(\mathrm{P}>0,05)$ entre os grupos ao longo dos tempos experimentais. S.C $=$ Sem consumo.

Tabela 4. Valores médios e desvio padrão do consumo de forragem (feno de tifton em gramas) entre os grupos ao longo do período de tratamento.

\begin{tabular}{|c|c|c|c|c|c|c|c|}
\hline & T0 & T8h & T24h & T48h & T72h & T120h & T168h \\
\hline GC & $267 \pm 13,41$ & S.C. ${ }^{\#}$ & S.C.* & S.C.* & S.C.* & $60,5 \pm 10,50^{\# *}$ & $92 \pm 15,50^{\#}$ \\
\hline GL & $267 \pm 18,14$ & S.C. ${ }^{\#}$ & $28,5 \pm 8,16^{\#}$ & $33 \pm 12,20$ & $117 \pm 10,16^{\#}$ & $199,0 \pm 10,54^{\#}$ & $261,4 \pm 10,31^{\#}$ \\
\hline GLH & $267 \pm 16,82$ & S.C." & $28,7 \pm 12,31^{\#}$ & $50,4 \pm 13,11^{\#}$ & $106,8 \pm 10,31^{\#}$ & $197,8 \pm 10,32^{\#}$ & $260,8 \pm 10,33^{\#}$ \\
\hline GLHC & $267 \pm 18,16$ & S.C. ${ }^{\#}$ & $26,7 \pm 12,12^{\#}$ & $40,4 \pm 13,63$ & $100,8 \pm 10,33^{\#}$ & $185,8 \pm 10,39^{\#}$ & $263,1 \pm 10,18^{\#}$ \\
\hline
\end{tabular}

Tabela 5. Valores médios e desvio padrão do consumo de forragem verde (g) entre os grupos ao longo do período de tratamento.

\begin{tabular}{cccccccc}
\hline & T0 & T8h & T24h & T48h & T72h & T120h & T168h \\
GC & $7 \pm 0$ & S.C. & S.C. & S.C. & S.C. & $3,2 \pm 1,1^{*}$ & $3,5 \pm 1,1 .^{*}$ \\
GL & $7 \pm 0$ & S.C. & S.C. & S.C. & $3 \pm 1,2^{\#}$ & $5,5 \pm 1,1$ & $7 \pm 0^{\#}$ \\
GLH & $7 \pm 0$ & S.C. & S.C. & S.C. & $3 \pm 1,4^{\#}$ & $5,5 \pm 1,1$ & $7 \pm 0^{\#}$ \\
GLHC & $7 \pm 0$ & S.C. & S.C. & S.C. & $4 \pm 1,2^{\#}$ & $5,5 \pm 1,3$ & $7 \pm 0^{\#}$ \\
\hline
\end{tabular}

\footnotetext{
${ }^{\#}$ Variação $(\mathrm{P}>0,05)$ dentro do grupo ao longo dos tempos experimentais; *Variação $(\mathrm{P}>0,05)$ entre os grupos ao longo dos tempos experimentais. S.C= Sem consumo.
}

\subsection{Avaliação laboratorial sérica e peritoneal}

\subsubsection{Avaliação hematológica}

Na avaliação da série vermelha foi possível verificar que não houve diferença significativa ( $p>0,05)$ em relação aos tempos experimentais ou mesmo entre os grupos tratados, conforme demonstrado na tabela 6, permanecendo dentro do valor basal (fisiológico) para a espécie, sem apresentar valor ou correlação clínica.

Tabela 6. Valores médios e desvio padrão da avaliação hematológica dos grupos experimentais.

\begin{tabular}{lcccccccc}
\hline & \multicolumn{2}{c}{ GC } & \multicolumn{2}{c}{ GL } & \multicolumn{2}{c}{ GLH } & \multicolumn{3}{c}{ GHC } \\
Hemácias & 4,530 & 0,39 & 4,610 & 0,35 & 4,760 & 0,37 & 4,750 & 0,39 \\
\hline
\end{tabular}




\begin{tabular}{lllllllll}
\hline Hemoglobina & 12,55 & 1,12 & 12,80 & 1,21 & 12,85 & 0,85 & 12,75 & 1,14 \\
Volume globular & 36,6 & 3,256 & 36,35 & 3,283 & 36,45 & 3,767 & 36.30 & 4,07 \\
Plaquetas & 40,45 & 54,78 & 339 & 71,64 & 367 & 41,55 & 303 & 66,88 \\
\hline
\end{tabular}

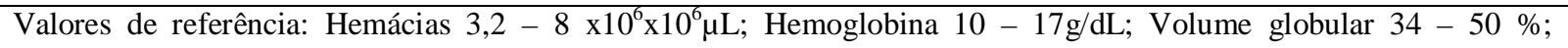
Plaquetas 40 - 80/ $\mu$ L. Eurell \& Frappier (2012)

Na série branca foi encontrada diferença significativa dos leucócitos com 24 horas, três e sete dias pós indução da peritonite fecal, como demonstrado no gráfico 2 ( $\mathrm{P}>0,05)$. Pode-se observar nos tempos experimentais que, para todos os grupos, houve elevação significativa dos

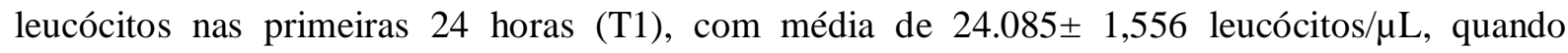

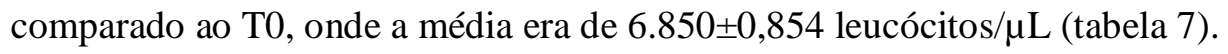

No GC, ao terceiro dia, observou-se leucopenia (3.070 \pm 1.018 leucócitos/ $\mu \mathrm{L})$, que se manteve nos demais tempos experimentais. Nova alteração significativa ocorre em T7, quando os valores de leucócitos retornaram aos valores basais. Nos grupos de tratamento (GL, GLH e GLHC) houve redução significativa dos leucócitos no terceiro dia $(5.070 \pm 0,699$ leucócitos/ $\mu \mathrm{L})$, retornando aos valores basais para a espécie, ao sétimo dia $(6.540 \pm 0,366$ leucócitos/ $\mu \mathrm{L})$.

Entre os grupos, GC foi significativamente diferente dos grupos de tratamento em T1, apesar de todos apresentarem leucocitose o GC apresenta diferença significativa quando comparado. Da mesma forma, em T3 e T7, os animais do GC apresentaram menores concentrações de leucócitos que os Grupos GL, GLH e GLHC. No tempo T3, o GLHC demonstrou maior leucopenia $(4,06 \pm$ 0,69 leucócitos $/ \mu \mathrm{L} ; \mathrm{P}>0,05)$ em relação aos outros dois grupos experimentais (GL e GLH)(figura 7).

Tabela 7. Valores médios e desvio padrão de leucócito nos grupos experimentais

\begin{tabular}{lcccc}
\hline & T0 & T1 & T3 & T7 \\
GC & $6.850 \pm 0,854$ & $26.085 \pm 1,556^{\#}$ & $3.070 \pm 1.018^{\# *}$ & $6.850 \pm 0,854^{\#}$ \\
GL & $6.850 \pm 0,854$ & $24.085 \pm 1,556^{\#}$ & $5.070 \pm 0,699^{\#}$ & $6.540 \pm 0,366$ \\
GLH & $6.850 \pm 0,854$ & $24.085 \pm 1,556^{\#}$ & $5.070 \pm 0,699^{\#}$ & $6.540 \pm 0,366$ \\
\hline
\end{tabular}




\begin{tabular}{|c|c|c|c|}
\hline GLHC & $6.850 \pm 0,854$ & $24.085 \pm 1,556^{\#} \quad 5.070 \pm 0,699^{\#}$ & $6.540 \pm 0,366$ \\
\hline
\end{tabular}

Figura 7. Avaliação da concentração leucocitária entre tratamentos durante as lavagens peritoneais.

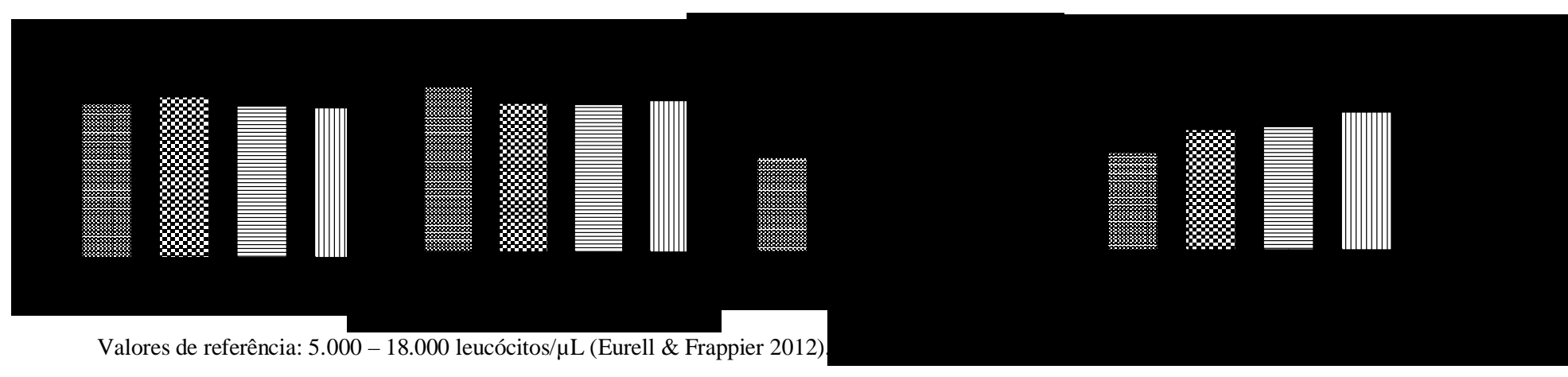

*Variação $(\mathrm{P}>0,05)$ entre grupos ao longo dos tempos experimentais

No que se refere aos neutrófilos, pode-se observar nos tempos experimentais (figura 7) que os grupos são homogêneos, com média de $2.120 \pm 189 / \mu \mathrm{L}$ em T0. No GC, foi observada a elevação

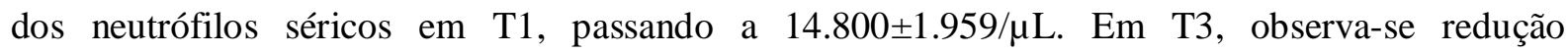
significativa da média para $11.000 \pm 558,6 / \mu \mathrm{L}$, sendo a próxima alteração $(\mathrm{P}>0,05)$ em $\mathrm{T} 7$, quando atinge sua menor marca, $9.945 \pm 749,5 / \mu \mathrm{L}$ ainda acima do fisiológico para a espécie.

Os grupos de tratamento (GL, GLH e GLHC) demonstram comportamento homogêneo, com elevação significativa quando comparados em T0 a T1, quando passam de $2.120 \pm 189 / \mu \mathrm{L}$ para $11,223 \pm 834 / \mu \mathrm{L}$ neutrófilos, respectivamente, apresentando neutrofilia evidente, seguido de reduções significativas em T3 para $8.452 \pm 358 / \mu \mathrm{L}$ e T7 para $3.408 \pm 932 / \mu \mathrm{L}$.

Quando comparados os grupos, a diferença entre GC e os grupos de tratamento ocorre em todos os tempos pós indução. Quando avaliado em T1, a média do GC se mantém em $14.800 \pm 1.959 / \mu \mathrm{L}$, enquanto nos grupos experimentais a média é de $11.223 \pm 834 / \mu \mathrm{L}$, mantendo a diferença em T3 e T7, enquanto GC apresenta média de (p>0,05). Foi verificada redução na contagem de neutrófilos no GC quando comparado aos grupos GL, GLH e GLHC, para valores dentro do basal para espécie, nos tempos experimentais demonstrados (tabela 8). 
Entre os tratamentos (GL, GLH e GLHC) não foram observadas diferenças significativas nos tempos experimentais (figura 8).

Tabela 8. Valores médios e desvio padrão de neutrófilos segmentado nos grupos experimentais

\begin{tabular}{|c|c|c|c|c|}
\hline & T0 & T1 & T3 & T7 \\
\hline GC & $2028 \pm 216,60$ & $14.800 \pm 1.959^{\#}$ & $11.000 \pm 558.6^{\# *}$ & $9.455 \pm 749.5^{*}$ \\
\hline GL & $2102 \pm 186,10$ & $11.250 \pm 629^{\#}$ & $8.700 \pm 420.9^{\#}$ & $3.617 \pm 640.9^{\#}$ \\
\hline GLH & $2087 \pm 202,80$ & $11.110 \pm 769,1^{\#}$ & $8.272 \pm 307.1^{\#}$ & $3.328 \pm 1148^{\#}$ \\
\hline GLHC & $2119 \pm 154,80$ & $11.310 \pm 1079^{\#}$ & $8.513 \pm 348,2^{\#}$ & $3.279 \pm 1010^{\#}$ \\
\hline
\end{tabular}

Figura 8. Dinâmica de neutrófilos segmentados durante os tratamentos.

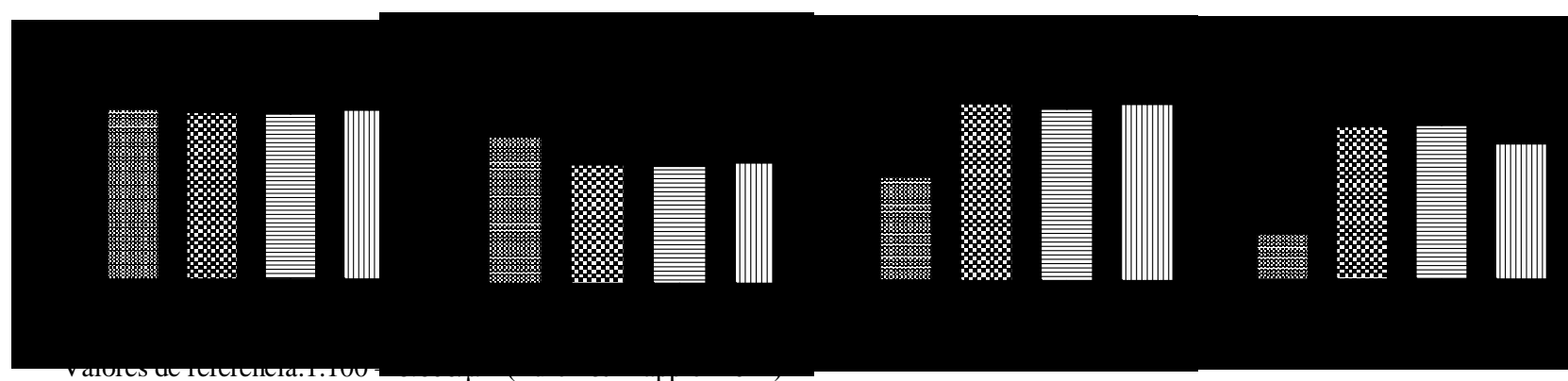

*Variação $(\mathrm{P}>0,05)$ entre grupos ao longo dos tempos experimentais

\subsection{Avaliação bioquímica sérica}

Avaliando a função renal, verifica-se, com relação à ureia, elevação significativa $(p>0,05)$ nos tempos T1, T3 e T7, em relação a T0, em todos os grupos experimentais (figura 9 e tabela 9), porém há redução significativa quando comparado T7 a T3(tabela 10).

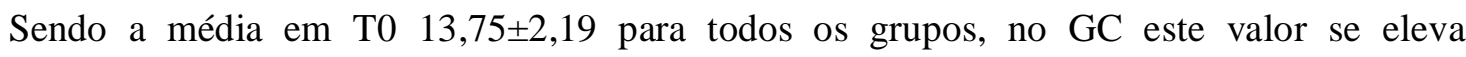

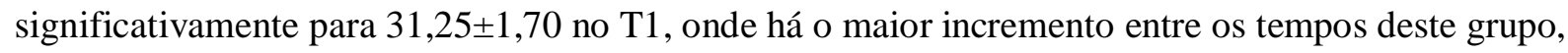
elevando-se em mais de 50\%. Segue elevando-se significativamente em T3 passando a 53,50 \pm 6.36 , reduzindo esta média significativamente apenas em T7, quando passa a 36,02 $\pm 1,44$. O GL segue o 


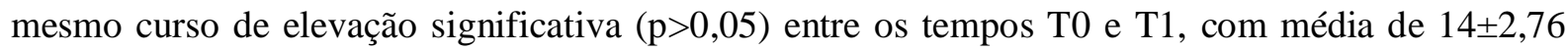
para $31,05 \pm 1,70$, segue em processo de elevação significativa em $\mathrm{T} 3$, quando a média vai à

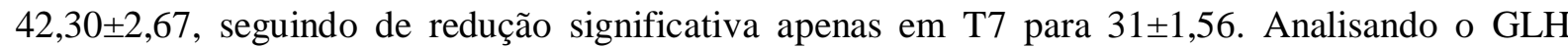
assim como os outros dois grupos segue com elevação significativa entre T0 e T1 passando de

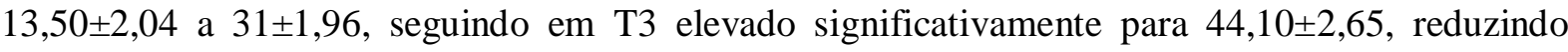
apenas em T7 quando atinge 32 $\pm 1,29$. No grupo GLHC o curso de T0, T1 e T3 é semelhante com elevação de $13,50 \pm 2,13$, para $32,30 \pm 0,79$ e $46 \pm 2,17$, respectivamente, reduzindo apenas em T7 como nos grupos anteriores para 33.05 $\pm 1,59$.

Quando analisados os resultados entre grupos experimentais, observamos diferença entre o GC e os grupos de tratamentos a partir de $\mathrm{T} 3$, quando os grupos com tratamento passam a apresentar menores médias de uréia. Entre os tratamentos (GL, GLH e GLH) não há diferença significativa em todos os tempos experimentais (figura 9).

Tabela 9. Valores médios e desvio padrão de ureia nos grupos experimentais

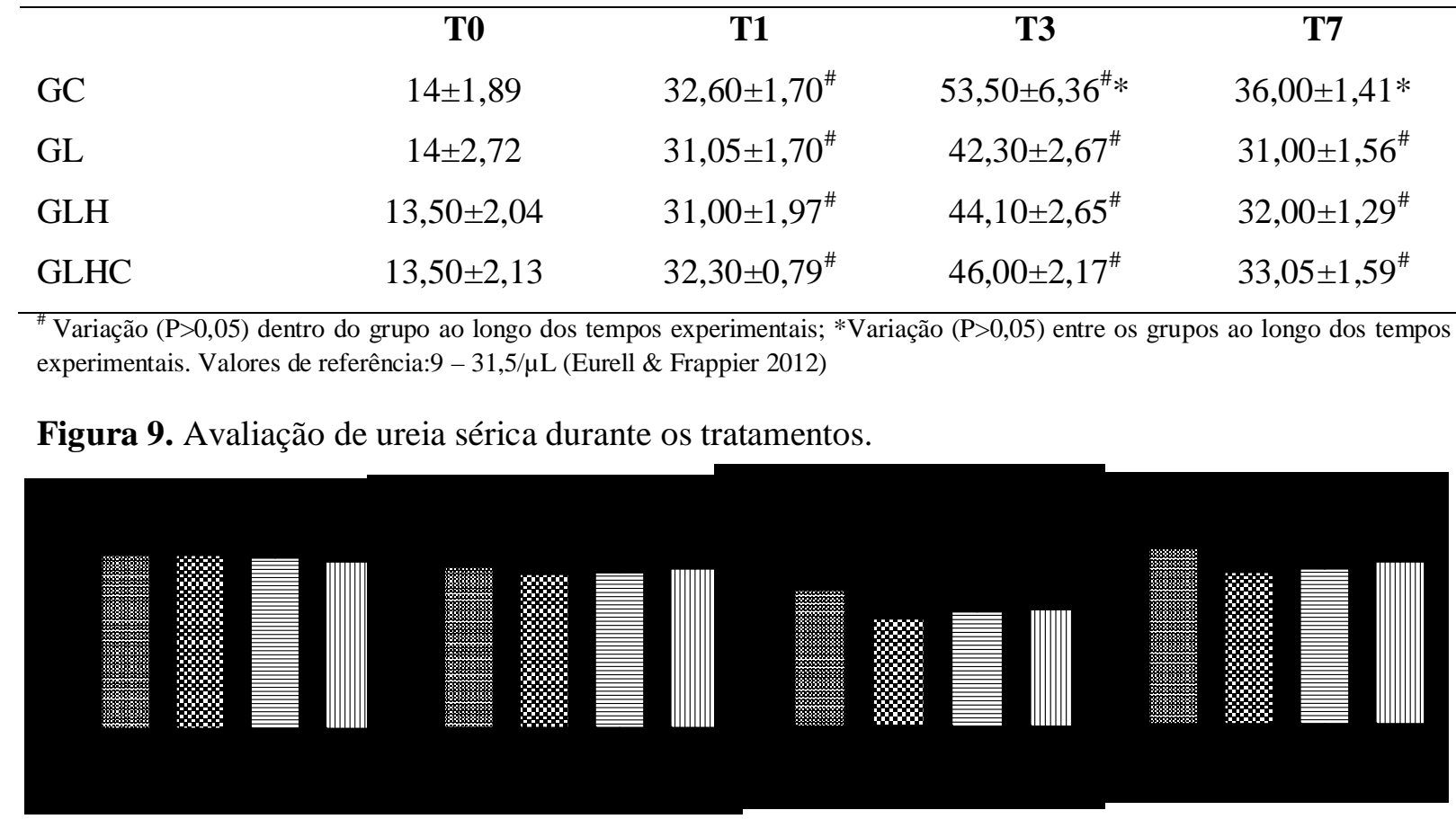


Com relação à creatinina (tabela 11; figura 12), o GC demonstra elevação em T1 e T7, em relação a T0 (p>0,05). Para o GL, GLH e GLHC verifica-se elevação de creatinina em T1, em relação a T0 (p>0,05).

Quando realizada a comparação entre tratamentos verificam-se maiores valores de creatinina em GC que nos tratamentos (GL, GLH e GLHC), somente em T1 e T3, em T7 já não há diferença significativa $(\mathrm{P}<0,05)$. Entre os tratamentos (tabela 10) não foram observadas diferenças significativas $(\mathrm{P}<0,05)$.

Tabela 10. Valores médios e desvio padrão de creatinina nos grupos experimentais.

\begin{tabular}{|c|c|c|c|c|}
\hline & T0 & T1 & T3 & T7 \\
\hline GC & $0,95 \pm 0,11$ & $3,10 \pm 0,40 * \#$ & $2,85 \pm 0.07 *$ & $2,75 \pm 0,21$ \\
\hline GL & $0,90 \pm 0,12$ & $2,40 \pm 0,28^{\#}$ & $2,40 \pm 0,27$ & $2,40 \pm 0,20$ \\
\hline GLH & $0,90 \pm 0,12$ & $2,40 \pm 0,25^{\#}$ & $2,40 \pm 0,25$ & $2,40 \pm 0,13$ \\
\hline GLHC & $0,90 \pm 0,13$ & $2,40 \pm 0,26^{\#}$ & $2,45 \pm 2,17$ & $2,40 \pm 0,28$ \\
\hline
\end{tabular}

Figura 10. Avaliação de creatinina sérica durante os tratamentos.

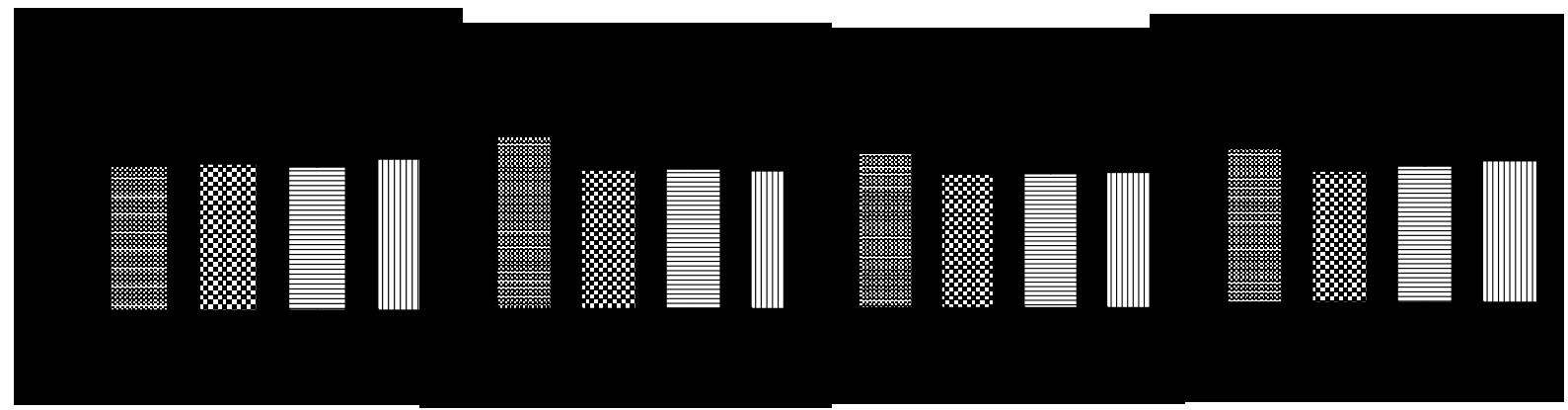

*Variação $(\mathrm{P}>0,05)$ entre grupos ao longo dos tempos experimentais

Na avaliação da função hepática, quando avaliados os valores de AST sérico, é demonstrada uma elevação significativa em T1 quando comparada a T0 e T3 quando comparado a T1, no GC esta alteração se mantém durante todos os tempos experimentais. Nos grupos de tratamento GL, GLH e GLHC até T3 há a elevação significativa, somente em T7 podemos verificar uma redução $(\mathrm{P}>0,05)$ para valores semelhantes a T1(tabela 12).

Quando comparados entre os grupos, GC difere significativamente em T3 dos grupos GL e GLH com médias mais elevadas, seguindo com diferença $(\mathrm{P}>0,05)$ em $\mathrm{T} 7$ em relação aos outros 
grupos experimentais. Com curso semelhante, o GLHC também se difere dos mesmos grupos (GL e GLH) em T3, passando a não haver diferença significativa em T7. Os grupos GL e GLH não apresentam diferença significativa entre si nos tempos avaliados (figura 11).

Tabela 11. Valores médios e desvio padrão de AST nos grupos experimentais.

\begin{tabular}{lcccc}
\hline & T0 & T1 & T3 & T7 \\
GC & $34,00 \pm 3,80$ & $61,50 \pm 10,27^{\#}$ & $74,50 \pm 7,78^{*}$ & $70,00 \pm 8,48^{*}$ \\
GL & $35.50 \pm 2,95$ & $62,50 \pm 4,78^{\#}$ & $69,00 \pm 7,07^{\#}$ & $62,00 \pm 6,366^{\#}$ \\
GLH & $35,00 \pm 3,46$ & $61,00 \pm 5,37^{\#}$ & $70,40 \pm 4,37^{\#}$ & $61,00 \pm 4,06^{\#}$ \\
GLHC & $34,00 \pm 2,84$ & $67,00 \pm 2,0^{\#}$ & $74,00 \pm 7,97 *^{\#}$ & $63,00 \pm 5,43^{\#}$ \\
\hline
\end{tabular}

\# Variação $(\mathrm{P}>0,05)$ dentro do grupo ao longo dos tempos experimentais; *Variação $(\mathrm{P}>0,05)$ entre os grupos ao longo dos tempos experimentais.

7.5. Avaliação físico química e bioquímica dos líquidos peritoneais.

Quanto à avaliação do líquido peritoneal, esta demonstrou evidência da influência dos tratamentos nos grupos tratados em relação ao grupo controle, no que se refere à avaliação física do líquido peritoneal ao ser coletado. Macroscopicamente, o líquido peritoneal se apresentava de coloração amarelo palha, com a presença de material fibrinoso nos primeiros 3 dias para todos os grupos. Somente o GC permaneceu com este padrão até o quinto dia, quando o líquido passou a apresentar um aspecto turvo, porém, sem a presença evidente de grânulos de fibrina. Este padrão foi mantido até o sétimo dia.

Para os demais grupos de tratamento (GL, GLH e GLHC), a partir do terceiro dia, o líquido manteve a coloração (amarelo palha), sem a presença de material fibrinoso, porém turvo, apresentando-se límpido somente no sétimo dia, quando passou a translúcido.

Para as variáveis sangue oculto e densidade, não foram observadas diferenças significativas entre grupos de tratamento $(\mathrm{p}<0,05)$, permanecendo em valores homogêneos durante toda fase de lavagem peritoneal (tabela 12). 
Tabela 12. Valores de sangue oculto e densidade em líquido peritoneal durante os tratamentos, para todos os grupos experimentais.

\begin{tabular}{|l|c|l|l|l|}
\hline & \multicolumn{1}{|c|}{ GC } & \multicolumn{1}{c|}{ GL } & \multicolumn{1}{c|}{ GLH } & \multicolumn{1}{c|}{ GHC } \\
\hline Sangue oculto $(/ \mu \mathrm{L})$ & $400 \pm 0$ & $400 \pm 26,26$ & $400 \pm 26,26$ & $400 \pm 26,26$ \\
\hline Densidade $(\mathrm{g} / \mathrm{dL})$ & $1007 \pm 2$ & $1005 \pm 3$ & $1006 \pm 3$ & $1008 \pm 2$ \\
\hline
\end{tabular}

No que se refere ao pH, foi observada redução no GC de T1 a T7, quando comparado com T0. No GL foi observado, em T1, redução do pH quando comparado a T0, seguindo de elevação significativa em T3 e manutenção em T7, sem diferença significativa destes dois tempos. No GLH e GLHC não foram observadas alterações significativas ao longo do tempo (tabela 13).

Tabela 13. Valores médios e desvio padrão de $\mathrm{pH}$ nos grupos experimentais.

\begin{tabular}{lcccc}
\hline & T0 & T1 & T3 & T7 \\
GC & $7,00 \pm 0,24$ & $5,00 \pm 0,60 *^{\#}$ & $5,25 \pm 0,35^{*}$ & $6,00 \pm 0 *^{\#}$ \\
GL & $7,00 \pm 0,24$ & $6,00 \pm 0,42 * *^{\#}$ & $7,00 \pm 0,21^{\#}$ & $7,00 \pm 0,26$ \\
GLH & $7,00 \pm 0,28$ & $6,75 \pm 0,82$ & $6,50 \pm 0,25$ & $7,00 \pm 0,26$ \\
GLHC & $7,00 \pm 0,21$ & $7,00 \pm 0,54$ & $7,50 \pm 0,53$ & $7,00 \pm 0,35$ \\
\hline \multicolumn{4}{r}{ \# Variação $(\mathrm{P}>0,05)$ dentro do grupo ao longo dos tempos experimentais; *Variação (P>0,05) entre os grupos }
\end{tabular}
ao longo dos tempos experimentais

Quando comparados os grupos, o GC demonstra significância em relação aos três grupos de tratamento (GL, GLH e GLHC), mantendo-se com $\mathrm{pH}$ de menor valor $(\mathrm{P}>0,05)$ durante todos os tempos experimentais. GL difere significativamente do GLHC, enquanto GLH não difere em relação ao GLHC (figura 11).

Figura 11. Avaliação do $\mathrm{pH}$ no líquido peritoneal durante tratamentos.

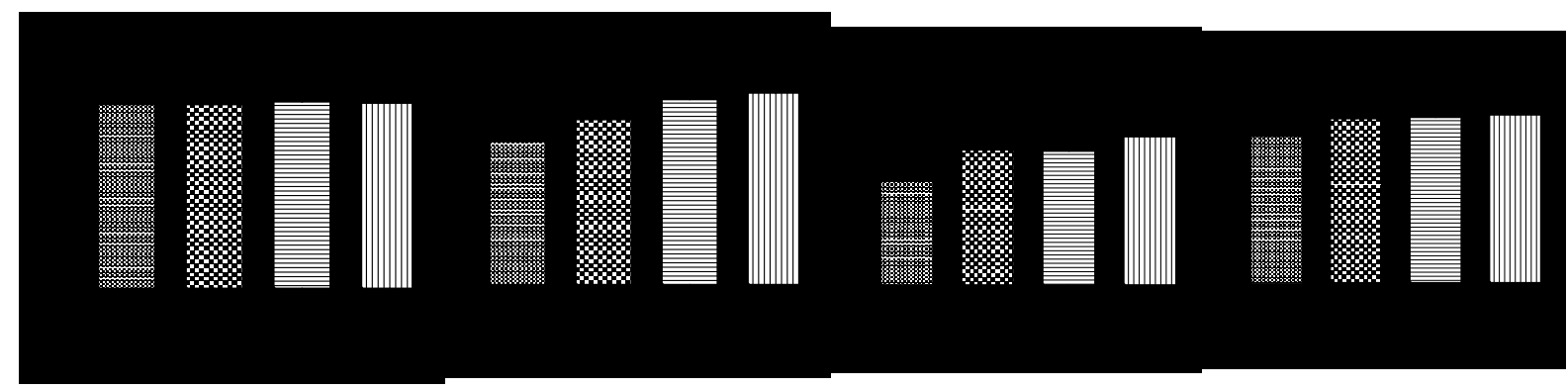


*Variação $(\mathrm{P}>0,05)$ entre grupos ao longo dos tempos experimentais

No que se refere à proteína no líquido peritoneal foi observado que, no GC, em T1 e T3, os valores se elevam de forma significativa, em relação a T0 (p>0,05). Em T7, verifica-se redução significativa, em relação a T0. No GL e GLH, verifica-se elevação em T1, em relação a T0, seguida de redução em T3 e T7 (p>0,05). No GLHC observa-se elevação em T1, em relação a T0 e redução em T7(tabela 14).

Tabela 14. Valores médios e desvio padrão de proteína nos grupos experimentais.

\begin{tabular}{lcccc}
\hline & T0 & T1 & T3 & T7 \\
GC & $0,10 \pm 0,03$ & $2,2 \pm 0,82^{*}$ & $2,85 \pm 1,06^{*}$ & $0,55 \pm 0,07 *^{\#}$ \\
GL & $0,10 \pm 0,03$ & $1,50 \pm 0,32^{\#}$ & $0,70 \pm 0,23^{\#}$ & $0,10 \pm 0,04^{\#}$ \\
GLH & $0,10 \pm 0,03$ & $1,60 \pm 0,26^{\#}$ & $1,00 \pm 0,27^{\#}$ & $0,20 \pm 0,08^{\#}$ \\
GLHC & $0,10 \pm 0,03$ & $1,80 \pm 0,16^{* \#}$ & $1,80 \pm 0,17 *$ & $0,80 \pm 0,1 *^{* \#}$ \\
\hline
\end{tabular}

\# Variação $(\mathrm{P}>0,05)$ dentro do grupo ao longo dos tempos experimentais; *Variação $(\mathrm{P}>0,05)$ entre grupos ao longo dos tempos experimentais

Quando comparados entre si, os grupos de tratamento (GL, GLH e GLHC) demonstram redução significativa de proteínas em T1 quando comparados a GC. Verifica-se que GL e GLH apresentam menores médias $(\mathrm{P}>0,05)$ de proteína no líquido peritoneal quando comparados com GLHC, a partir de T3 até T7. Não há diferença significativa entre GC e GLH a partir de T1 (figura 12).

Figura 12. Avaliação da proteína no líquido peritoneal durante os tratamentos

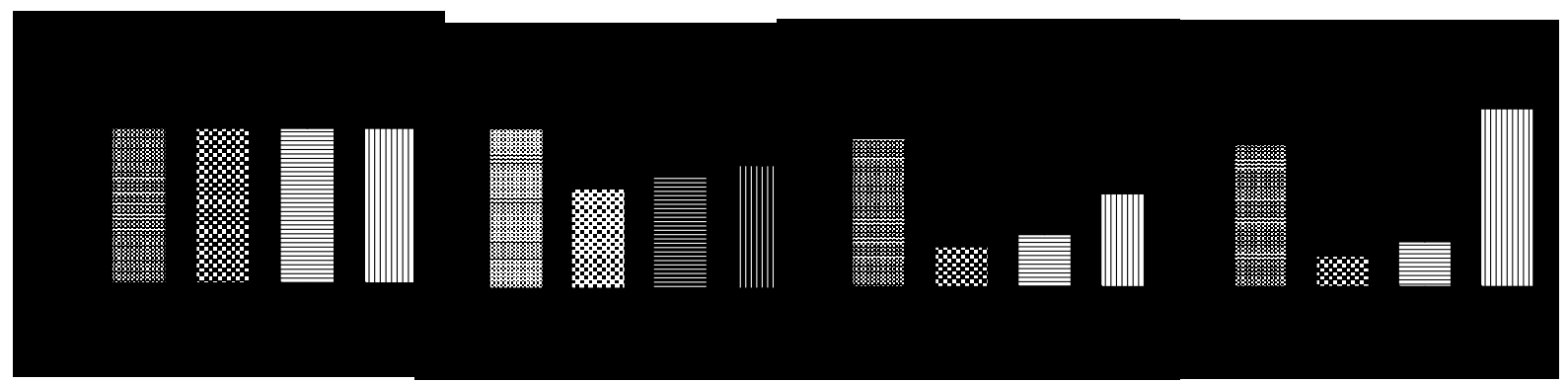

. *Variação $(\mathrm{P}>0,05)$ entre grupos ao longo dos tempos experimentais

Para a glicose peritoneal (figura 15), todos os grupos demonstraram elevação significativa em T1. Os GC e GLHC mantém elevação de glicose peritoneal em T3 e T7. Os GL e GLH apresentam redução em T3 e T7 $(\mathrm{P}<0,05)($ tabela15). 
O GC mantém a elevação significativa em T3 sem significância para a variação em T7. Já o GL demonstra redução significante em T3 semelhante ao GLH, bem como há a redução significativa em T7. De forma semelhante o GLH quando comparado pelos tempos demonstra redução significativa T3 e T7. Já o GLHC apresenta assim como nos outros grupos, elevação significativa em T1 quando comparado a T0, sendo mantida em todos os tempos experimentais sem alteração.

Tabela 15. Valores médios e desvio padrão de glicose nos grupos experimentais.

\begin{tabular}{lcccc}
\hline & T0 & T1 & T3 & T7 \\
GC & $0,10 \pm 0,03$ & $2,2 \pm 0,82 *^{\#}$ & $2,85 \pm 1,06^{*}$ & $0,55 \pm 0,07 *^{\#}$ \\
GL & $0,10 \pm 0,03$ & $1,50 \pm 0,32^{\#}$ & $0,70 \pm 0,23^{\#}$ & $0,10 \pm 0,04^{\#}$ \\
GLH & $0,10 \pm 0,03$ & $1,60 \pm 0,26^{\#}$ & $1,00 \pm 0,27^{\#}$ & $0,20 \pm 0,08^{\#}$ \\
GLHC & $0,10 \pm 0,03$ & $1,80 \pm 0,16^{* \#}$ & $1,80 \pm 0,17 *$ & $0,80 \pm 0,1 *^{* \#}$ \\
\hline \multicolumn{4}{l}{ " Variação (P>0,05) dentro do grupo ao longo dos tempos experimentais; *Variação (P>0,05) entre grupos ao longo dos } \\
tempos experimentais
\end{tabular}

Quando analisada entre os grupos é possível demonstrar alteração significativa entre GC e os grupos de tratamento (GL, GLH e GLHC) em T3. Em T7 não há diferença significativa entre GC e GLHC. Não há diferença significativa entre GL e GLH em T3 e T7.

Figura 13. Avaliação da glicose no líquido peritoneal durante os tratamentos.

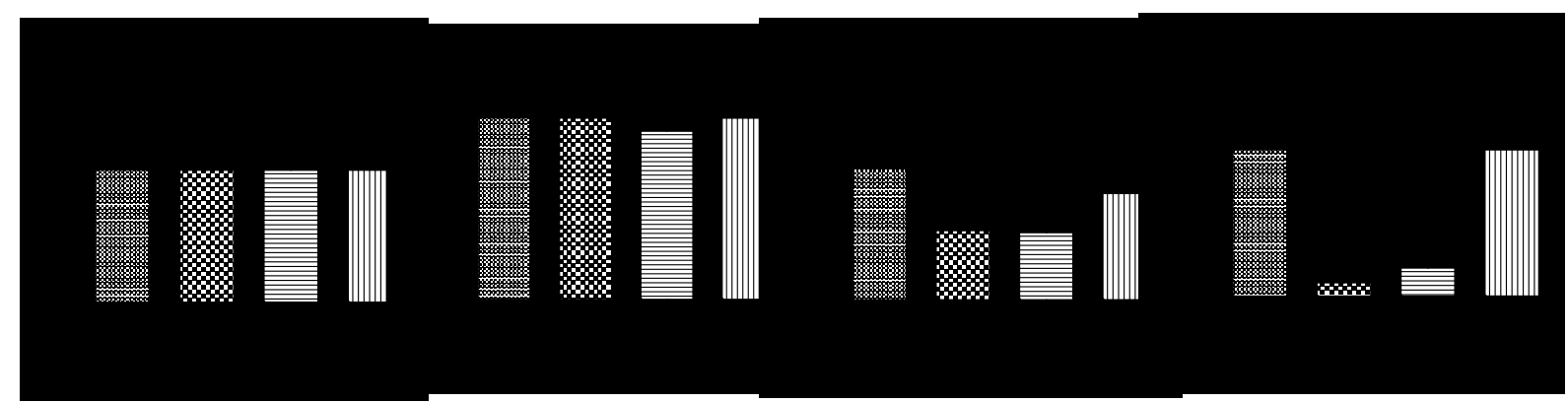

*Variação $(\mathrm{P}>0,05)$ entre grupos ao longo dos tempos experimentais 
Todos os animais apresentam média em T0 de $0 \pm 22$ células $/ \mu \mathrm{L}$, desta forma o GC apresenta significativa elevação na contagem total em T1, já em T3 apresenta redução média significativa, seguida por reduções em T4 e T5, somente em T7 volta a ser significativa. Para GL assim como para os outros grupos a significância se dá quando compara T0 e T1, seguido de reduções $(\mathrm{P}>0,05)$ em T2 e T3 com média, chegando em T6 à valores encontrados em T0. Para GLH o comportamento é semelhante ao GL, sem diferença significativa entre os tempos. Já GLHC demonstra diferença significativa em T1 quando comparado a T0, nova variação ocorre em T4, T6, e T7 (tabela16).

Quando comparados os grupos, verifica-se diferença entre GC e os tratamentos (GL, GLH e GLHC) de T1 até o T4, sendo que GC apresenta maior celularidade peritoneal. A partir de T5, não há diferença entre os grupos experimentais. Verifica-se maior celularidade peritoneal no GLHC em relação aos grupos GL e GLH em todos os tempos a partir de T1 (figura 14).

Tabela 16: Valores médios e desvio padrão da avaliação para contagem de células total/ $\mu 1$ (CT)

\begin{tabular}{lcccccccc}
\hline & T0 & T1 & T2 & T3 & T4 & T5 & T6 & T7 \\
GC & $0 \pm 24$ & $22015 \pm 438^{\# *}$ & $22440 \pm 662^{\# *}$ & $9600 \pm 501^{\# *}$ & $5700 \pm 124^{*}$ & $1300 \pm 126^{*}$ & $990 \pm *$ & $237 \pm 98^{*}$ \\
GL & $0 \pm 22$ & $5260 \pm 165^{\#}$ & $2610 \pm 212$ & $782 \pm 102^{\#}$ & $334 \pm$ & $36 \pm^{\#}$ & $6 \pm 14^{\#}$ & $6 \pm 18$ \\
GLH & $0 \pm 24$ & $7110 \pm 462^{\#}$ & $4275 \pm 684^{\#}$ & $1933 \pm 722^{\#}$ & $814 \pm 736$ & $88 \pm 50^{\#}$ & $8 \pm 10^{\#}$ & $7 \pm 14$ \\
GLHC & $0 \pm 23$ & $13930 \pm 1944^{\# *}$ & $10905 \pm 1643^{*}$ & $10125 \pm 1768^{\# *}$ & $3174 \pm 389^{\# *}$ & $2031 \pm 392^{*}$ & $995 \pm 126^{\# *}$ & $273 \pm 102^{\# *}$ \\
\hline "Variação (P>0,05) dentro do grupo ao longo dos tempos experimentais; *Variação (P>0,05) entre grupos ao longo dos tempos
\end{tabular}

Figura 14. Variação da celularidade total no líquido peritoneal de cobaias durante os tratamentos. 


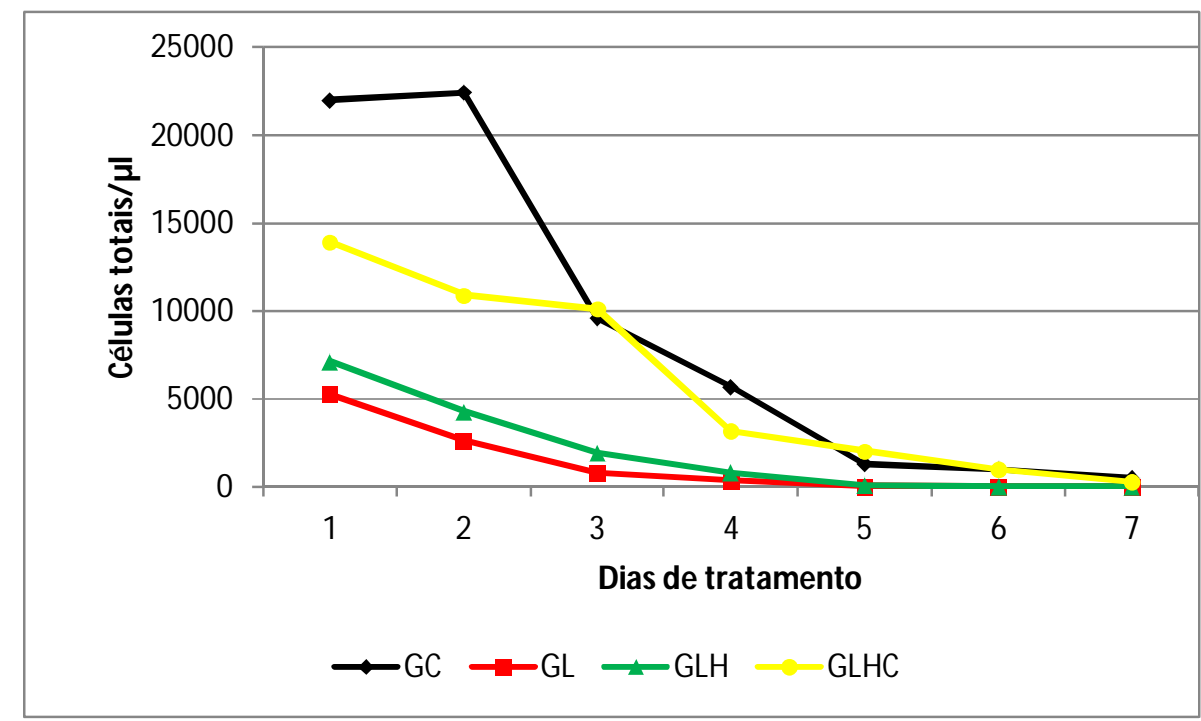

Avaliando a presença de macrófagos na celularidade peritoneal em T0 foram encontrados $2 \pm 2$ células $/ \mu \mathrm{L}$, assim todos os grupos demonstraram significância em elevação na quantidade de macrófagos em T1, sendo que o GC apresenta redução significativa em T3, T5 e T7. O GL assim como GLH apresentaram valores significativos quando comparados T0 e T1, ambos demonstram significância ( $p>0,05)$ na redução a partir de T3 e novamente em T5, assim seguindo até T7. O GLHC assim como os demais grupos mantém em T1 elevação significativa quando comparado a T0, havendo redução significativa apenas em T5 e seguindo até T7 (tabela 17).

Quando comparados entre si nos tempos há variação significativa entre GC e os grupos GL e GLH desde T1 a T7, bem como há variação significativa entre GLHC e os demais grupos a partir de T1 a T7. Há significância entre os grupos GL e GLHC quando comparados aos grupos GC e GLHC, porém sem variação quando comparados entre si a partir de T4, até este tempo GL apresenta menores valores $(\mathrm{P}>0,05)$ (figura 15$)$.

Tabela 17: Valores médios e desvio padrão da avaliação para contagem de macrófago/ $\mu \mathrm{L}$

\begin{tabular}{ccccccccc}
\hline & T0 & T1 & T2 & T3 & T4 & T5 & T6 & T7 \\
GC & $0 \pm 1,00$ & $65 \pm 15,22^{\# *}$ & $59 \pm 39,17^{*}$ & $45 \pm 36,12^{*}$ & $36 \pm 42,30^{\# *}$ & $27 \pm 8,10^{\# *}$ & $27 \pm 12,10^{*}$ & $15 \pm 12,90^{\# *}$ \\
GL & $1 \pm 0,5$ & $30 \pm 10,08^{\#}$ & $19 \pm 17,11$ & $9 \pm 9,98^{\#}$ & $2 \pm 1,67^{\#}$ & $2 \pm 1,62$ & $1 \pm 1,20$ & $1 \pm 1,00$ \\
GLH & $0 \pm 1,00$ & $38 \pm 3,46^{\#}$ & $25 \pm 15,47$ & $16 \pm 5,23$ & $9 \pm 2,37$ & $4 \pm 1,89$ & $4 \pm 1,60$ & $1 \pm 1,83^{\#}$ \\
GLHC & $0 \pm 1,00$ & $99 \pm 11,14^{\# *}$ & $103 \pm 22,32^{*}$ & $101 \pm 12,02^{*}$ & $97 \pm 5,78^{*}$ & $43 \pm 6,01 *$ & $43 \pm 12,52^{*}$ & $43 \pm 14,36^{*}$
\end{tabular}

\# Variação $(\mathrm{P}>0,05)$ dentro do grupo ao longo dos tempos experimentais; *Variação $(\mathrm{P}>0,05)$ entre grupos ao longo dos tempos
experimentais. 
Figura 15. Variação de macrófagos no líquido peritoneal de cobaias durante os tratamentos.

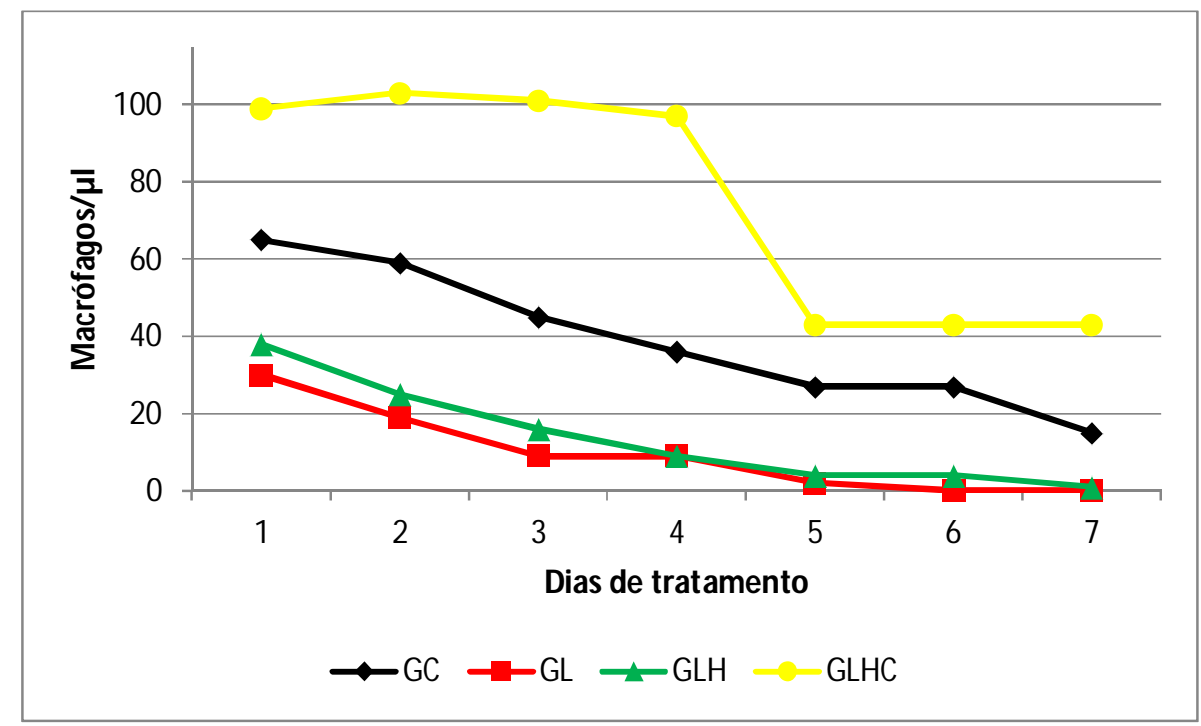

Quando são avaliados os neutrófilos encontrados no líquido peritoneal (tabela19 e figura figura 18) em T0 a média de $1 \pm 1$ células/ $\mu \mathrm{L}$ para todos os grupos, assim o GC demonstrou elevação significante T1, havendo redução significativa apenas em T5 e novamente em T7. Os grupos GL e GLH não diferiram nos tempos estabelecidos, seguindo com redução $(\mathrm{P}>0,05)$ em T3 e retorno a condição inicial pré inoculação em T7. Já o GLHC não demonstrou variação significativa a partir de T1 durante os tempos experimentais.

Quando comparado o GC demonstrou significância em relação aos grupos de tratamento até T4, quando não houve mais significância até T7, quando demonstra menor significância em relação ao GLHC. Os GL e GLH apresentam diferença quando comparados ao GC em todos os tempos experimentais e ao GLHC a partir de T2, não demonstraram diferença entre si (tabela 18 e figura 16).

Tabela 18: Valores médios e desvio padrão da avaliação para contagem de neutrófilo/ $\mu \mathrm{L}$

\begin{tabular}{ccccccccc}
\hline & T0 & T1 & T2 & T3 & T4 & T5 & T6 & T7 \\
GC & $0 \pm 1,00$ & $65 \pm 15,22^{\# *}$ & $59 \pm 39,17^{*}$ & $45 \pm 36,12^{*}$ & $36 \pm 42,30^{\# *}$ & $27 \pm 8,10^{\# *}$ & $27 \pm 12,10^{*}$ & $15 \pm 12,90^{\# *}$ \\
GL & $1 \pm 0,5$ & $30 \pm 10,08^{\#}$ & $19 \pm 17,11$ & $9 \pm 9,98^{\#}$ & $2 \pm 1,67^{\#}$ & $2 \pm 1,62$ & $1 \pm 1,20$ & $1 \pm 1,00$ \\
GLH & $0 \pm 1,00$ & $38 \pm 3,46^{\#}$ & $25 \pm 15,47$ & $16 \pm 5,23$ & $9 \pm 2,37$ & $4 \pm 1,89$ & $4 \pm 1,60$ & $1 \pm 1,83^{\#}$ \\
GLHC & $0 \pm 1,00$ & $99 \pm 11,14^{\# *}$ & $103 \pm 22,32^{*}$ & $101 \pm 12,02^{*}$ & $97 \pm 5,78^{*}$ & $43 \pm 6,01^{*}$ & $43 \pm 12,52^{*}$ & $43 \pm 14,36^{*}$ \\
\hline & Variação (P>0,05) dentro do grupo ao longo dos tempos experimentais; *Variação (P>0,05) entre grupos ao longo dos tempos \\
experimentais &
\end{tabular}


Figura 16. Variação dos neutrófilos no líquido peritoneal de cobaias durante os tratamentos.

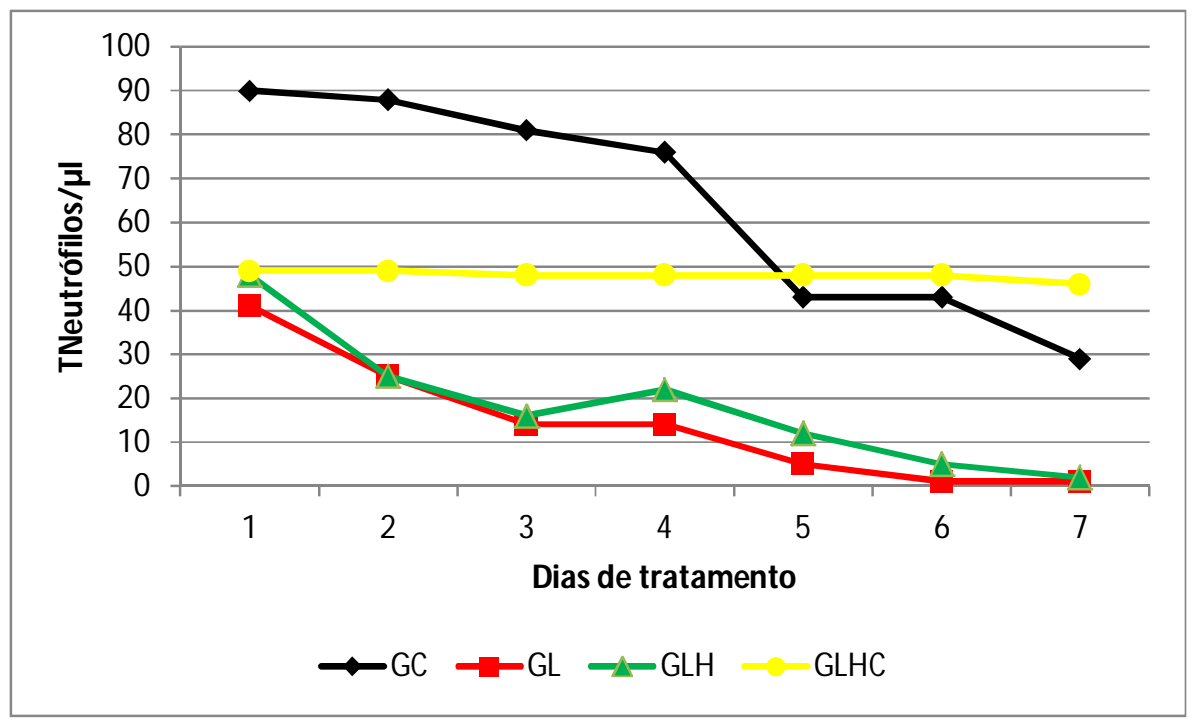

Ao avaliar lactato e fibrinogênio peritoneal não houve variação significativa nos valores dentro dos tempos experimentais desde o T0 a T7 ou entre ainda grupos, tal resultado pode estar relacionado a baixa resposta que os animais apresentam frente ao estímulo, considerando como particularidade da espécie.

\subsection{Avaliação macroscópica dos achados abdominais.}

Quanto aos achados macroscópicos post-mortem foram verificadas evidências claras entre os animais que não foram lavados (GM) ou que foram lavados somente com solução de Ringer lactato e os tratamentos (GL, GLH e GLHC). Em nenhum dos grupos foi observada a presença de fistula ou abcesso na face externa da parede abdominal (figura 17).

Figura 17. Aspecto da parede abdominal externa, sem a presença de foco purulento e aderências.

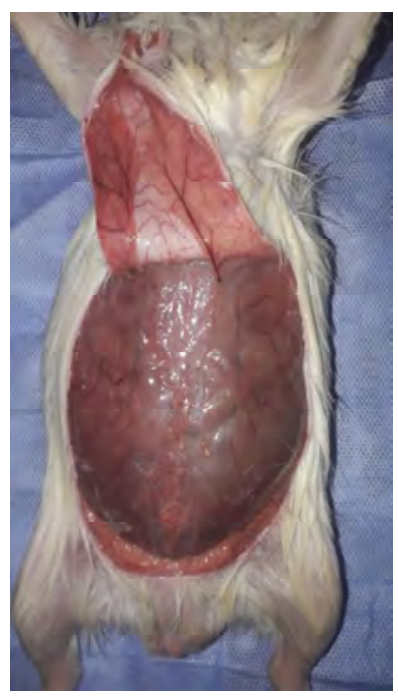


No grupo modelo de indução (GM), onde não foi administrada nenhuma solução abdominal, apenas tratamento sistêmico, as aderências puderam ser visualizadas em toda cavidade, entre órgão e a parede abdominal, com grande quantidade de material fibrinoso aderido e aderindo as vísceras, com evidente sitio nas alças de intestino delgado, sendo considerada de grau 4 (figura 18), ou seja, aderências firmes, resistentes à manipulação durante a necropsia, com ligação entre parede abdominal e mais de um órgão.

Figura 18. Aderências abdominais em animais do grupo modelo de indução (GM), evidenciando aderência entre órgãos e a parede abdominal.
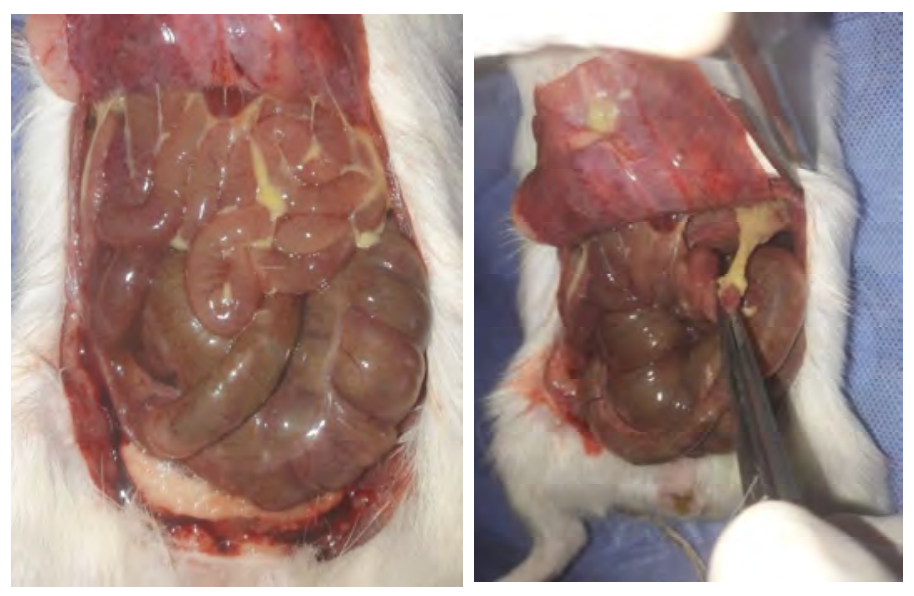

Assim, as aderências puderam ser facilmente visualizadas, sendo necessária a secção de algumas delas para que se pudesse evidenciar a cavidade na incisão em "U" utilizada.

No grupo controle GC, onde foi utilizado solução de ringer com lactato, as aderências puderam ser visualizadas de maneira clara entre órgãos e parede abdominal, com evidente presença entre as vísceras e maior prevalência no intestino delgado, sítio da maioria das aderências grau 3, ou seja, a presença de aderências firmes, resistentes a manipulação, entre a parede abdominal e apenas um órgão (intestino delgado-jejuno) (figura 19). 
Figura 19. Aderências abdominais em animais do grupo controle (GC), evidenciando aderência entre órgãos e a parede abdominal.

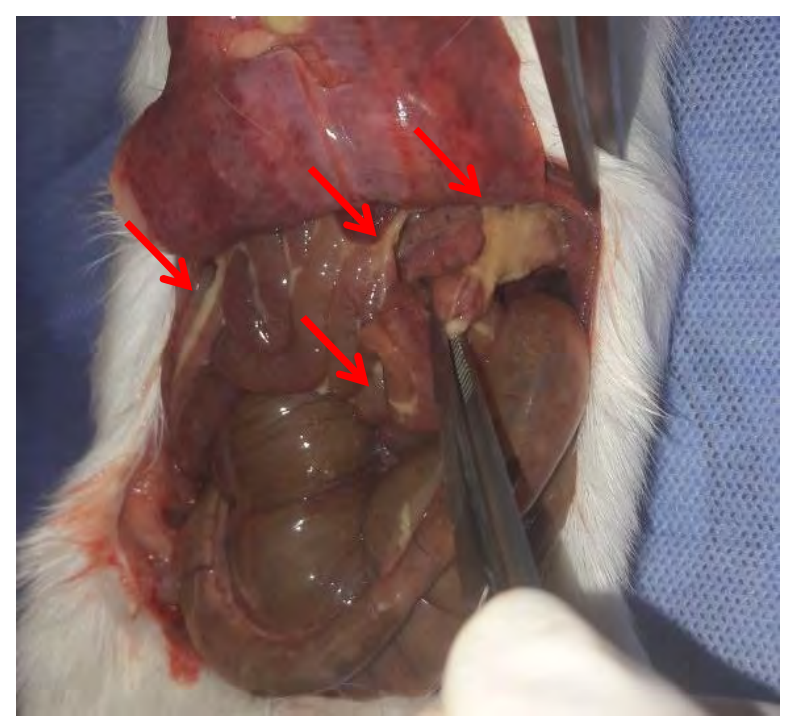

Não foram observadas, dentro do mesmo grupo, diferenças entre as aderências, em relação ao tempo de óbito, sendo classificadas como aderências firmes, que não se rompiam com a movimentação das alças intestinais com auxílio de pinças anatômicas.

Nos Grupo 1 (GL) e 2 (GLH), as aderências não foram visualizadas, os órgãos encontravamse sem a presença de fibrina livre ou fibrina causando aderência entre órgão e a parede abdominal. A cavidade abdominal apresentava vísceras brilhantes, topografia mantida, segmentos intestinais compatíveis com a movimentação intestinal normal. Nos grupos 1 e 2, um animal de cada grupo (10\%), apresentaram concentrações isoladas de fibrina, presente em órgãos localizados mais cranialmente, no grupo GL foram encontrados focos de fibrina aderidos caudo-dorsalmente ao baço e fígado, que não uniam nenhum segmento a outro (figura 20).

Figura 20. Avaliação macroscópica (post mortem) de cobaias 

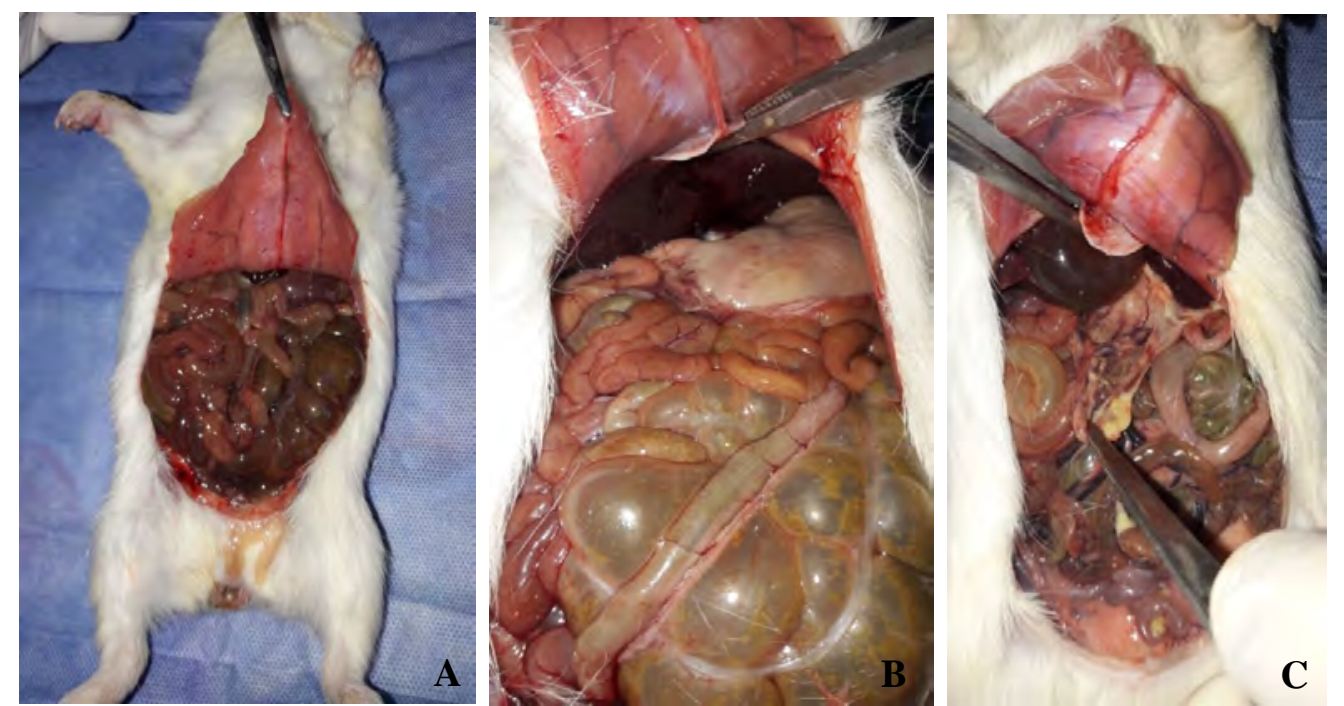

A /B- Vísceras sem a presença de fibrina e brilhantes com topografia preservada (GL/GLH); C - Pequena presença de fibrina aderida a segmento intestinal (duodeno) sem aderir a outro segmento/órgão(GL) em um animal.

No grupo 3 (GLHC), três animais (30\%) apresentaram aderências focais entre segmento de intestino delgado (duodeno) e parede abdominal, sendo as aderências classificadas em grau 3, ou seja, a presença de grânulos livres ou focalmente localizados sem aderir segmentos ou facilmente desfeitas pela manipulação (figura 21). Era possível visualizar uma película densa recobrindo os órgãos. Além disso, o líquido peritoneal apresentava-se levemente mais viscoso, em relação aos demais grupos experimentais.

Figura 21. Avaliação macroscópica (post mortem) de cobaias (GLHC)
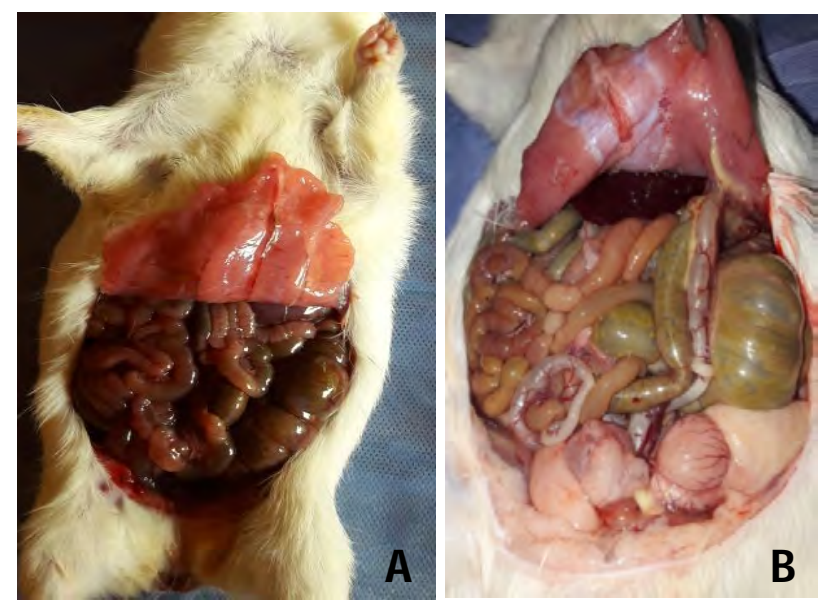
A - Vísceras sem a presença de fibrina dispersa na cavidade e com aspecto brilhante com topografia preservada; B - Pequena presença de fibrina aderida a parede abdominal com segmento intestinal (jejuno) levemente aderido e facilmente desfeito pela manipulação sem tração (GLHC).

$\mathrm{Na}$ etapa de necropsia, não foram observadas alterações macroscópicas dos órgãos abdominais em nenhum dos grupos experimentais, como hiperemia, opacidade, aumentos de volume ou coloração disforme.

\subsection{Avaliação histopatológica de rim e fígado}

$\mathrm{Na}$ avaliação histológica foram analisados fígado e rim direito de todos os animais, buscando similaridades de possíveis lesões causadas pelo processo toxêmico e em resposta ao quadro de sepse (metabolização e excreção). Os achados demonstraram padrões semelhantes de alterações dentro do mesmo grupo, assim foram atribuídas notas que vão de 0 a 4 de acordo com o perfil encontrado, sendo as notas mais altas atribuídas a lesões que podem comprometer a função do órgão.

Em tecido renal, levou se em consideração: Edema de interstício, infiltrado inflamatório, localização (se presente apenas em córtex renal ou extrapolando para pelve), apoptose/necrose renal. Em tecido hepático considerou-se: forma dos hepatócitos, forma dos canalículos hepáticos, presença de tecido fibroso entre os hepatócitos e necrose hepática/periportal.

No GC, em tecido renal, foram encontrados predominantemente, edema e infiltrado inflamatório difuso no interstício, bem como pode ser evidenciado o achatamento moderado das células tubulares, sendo caracterizada como grau três para todas as características avaliadas. No tecido hepático, foram observados edema, aumento dos canalículos hepáticos com presença de áreas de necrose em hepatócitos, acometendo cerca de $28 \%$ do tecido. Foi possível verificar aumento de área nos hepatócitos, que não estavam necrosados, sendo atribuído nota três. Sendo assim, verificase indícios de lesão nos órgãos avaliados.

No GL, o tecido renal apresentou discreto edema, com pequena quantidade de infiltrado inflamatório no interstício, circunstanciada à borda do córtex. Não foi encontrado indício de 
achatamento das células tubulares, indicando uma maior qualidade do órgão, sendo atribuída nota um aos achados. Em relação ao tecido hepático, não foram observados edema periportal, sem área evidente de necrose e hepatócitos com pequena distensão, de maneira homogênea por todo tecido avaliado, sendo atribuído nota zero. Verificou-se, portanto, que os animais do GL apresentaram maior preservação de rim e fígado em relação ao $\mathrm{GC}$, sem indícios de lesões que pudessem comprometer o funcionamento dos orgãos.

No GLH, foi verificado no tecido renal, moderado edema, com discreta quantidade de infiltrado inflamatório difuso no interstício. Não foi encontrado indício de achatamento das células tubulares, atribuindo-se nota um aos achados. No tecido hepático, não foram observados edema periportal, sem área evidente de necrose e hepatócitos com discreta distensão, de maneira homogênea por todo tecido, sendo atribuído nota um. Assim, verificou-se que o fígado e rim se encontravam em condição mais preservada em relação ao GC. Porém, o fígado apresentava-se em pior preservação que GL, embora esses achados não constituem indícios de lesões que pudessem comprometer o funcionamento dos órgãos.

No GLHC, verificou-se no tecido renal, edema moderado, com moderada quantidade de infiltrado inflamatório no interstício difuso, não sendo encontrado indício de achatamento das células tubulares. Foi observado discreto desnudamento da membrana basal na região cortical, atribuindo-se nota dois aos achados. No tecido hepático, foram observados discreto edema periportal, sem área evidente de necrose e hepatócitos com pequena distensão, de maneira homogênea por todo tecido avaliado, sendo atribuída nota dois. Assim, verificaram-se tecidos em condição mais preservada em relação ao GC, porém em pior condição de preservação de função em relação a GL e GLH. 


\section{DISCUSSÃO}

A peritonite, quando causada por contaminação fecal, apresenta elevada mortalidade, devido à formação de aderência e choque séptico/toxêmico (PAGLIOSA \& ALVES 2004; PIHL et al. 2014). O peritônio é uma membrana semipermeável e contém múltiplos e diferentes poros, possuindo as propriedades de um dialisador, contribuindo com a remoção de patógenos e exsudato cáustico formado pelos precursores inflamatórios na cavidade abdominal (BROCCO et al. 2008; ANDERSON et al 2011; AITKEN et al 2015). A lavagem peritoneal apresenta-se como uma ferramenta de grande auxílio, que quando corretamente empregada, pode reduzir a inflamação e a formação de aderências intra-abdominais. A utilização do acesso peritoneal como via de tratamento para infecções abdominais, ou seja, via de administração de fármacos, apresenta resultados promissores, como demonstrado neste estudo, nos aspectos que tangem o controle da reação inflamatória, a prevenção e redução da formação de aderências e o combate à infecção bacteriana local.

Este estudo evidencia a influência da lavagem peritoneal no tratamento de peritonite em cobaias submetidas à peritonite fecal. Verificou-se que a lavagem peritoneal, repetida a cada oito horas, é benéfica, mesmo se realizada apenas com solução de Ringer lactato onde foi possível demonstrar uma sobrevida de $20 \%$ dos animais. Os resultados apresentaram-se melhores ao se adicionar lidocaína à lavagem peritoneal com Ringer lactato, onde foi demonstrada uma sobrevida de $90 \%$ do animais, assim como com a adição de heparina à solução de Ringer lactato e lidocaína, onde foi encontrada semelhante taxa de sobrevida. Por outro lado, a adição de carboximetilcelulose à solução de Ringer lactato, lidocaína e heparina não se mostrou interessante, visto que a taxa de sobrevida de animais foi de $80 \%$.

Os acessos para o posicionamento da sonda de lavagem peritoneal no flanco citado por Alonso (2016) e no abdômen ventral se mostraram efetivos, assim como demonstrado por Silva 
et al. (2018), corroborando as vantagens de dois acessos independentes, reduzindo a ressuspenção de agentes contaminantes, como possivelmente ocorre quando se utiliza o mesmo acesso abdominal ventral para infusão de soluções e drenagem.

A quantidade de fluido para lavar a cavidade peritoneal de $30 \mathrm{ml}$ mostrou-se ideal para cobaias, visto que $90 \pm 5 \%$ da cavidade foi embebida com solução, permitindo a lavagem dos órgãos abdominais. Carneiro et al. (2002), Gusso (2018) \& Silva et al. (2018) reiteram a importância da lavagem profusa do abdômen, em ratos, cães e equinos, respectivamente, porém, o volume baseia-se na sensação de conforto e desconforto ao paciente, bem como na coloração do líquido resgatado. Assim, também faz se necessária uma avaliação vídeo laparoscópica, reduzindo a subjetividade dos parâmetros citados em literatura, principalmente quando se objetiva dispersar soluções com potencial sinérgico.

O consumo de alimento e água é fundamental para manutenção do equilibro e saúde em todas as espécies. Para se verificar a higidez de cobaias enfermas, os parâmetros ingestão de alimento e consumo de água mostraram-se viáveis, uma vez que se apresentaram diretamente correlacionados. Verificou-se que os animais reduziam as quantidades e paravam de se alimentar e hidratar quando estavam enfermos, até irem a óbito. Esta condição também foi observada em estudos com ratos por Carneiro et al. (2002) e com equinos por Nógradi et al. (2011) \& Pollock (2012).

Com relação à escala de avaliação de dor e desconforto, verificou-se que a mesma foi funcional, sendo indispensável, assim como citado por Oliveira et al. (2019) e demonstrado em estudo com roedores por Patrick \& Villano (2013). Neste estudo, verificava-se que o desconforto gerado pela quadro de peritonite possuía maior correlação com o quadro sistêmico do que o quadro local, uma vez que não houve sinal clínico comportamental de dor com o animal em estação ou quando manipulado, e sim apatia profunda no quadro de sepse, quando os 
animais apresentavam-se enfermos até irem a óbito semelhante ao que ocorre com equinos, como demonstrado por Oliveira et al (2014) \& Silva et al (2018).

Neste estudo, foi verificado que apenas o tratamento sistêmico com antibioticoterapia de amplo espectro e anti-inflamatório não esteroidal, além de analgesia, não são suficientes para promover a sobrevida de animais com peritonite fecal, visto que todos os animais do GM foram a óbito nas primeiras 22 horas, sendo o primeiro com 12 horas após a indução, corroborando com a hipótese deste trabalho, sobre a importância da lavagem peritoneal, assim como demonstrado pela literatura (Silva et al., 2018). Verificou-se que a adição de lavagem peritoneal, com solução de Ringer lactato, a cada oito horas, auxilia no tratamento da peritonite fecal e eleva a sobrevida dos animais, uma vez que $20 \%$ dos animais sobreviveram durante todo o período de avaliação e $80 \%$ vieram a óbito com $17,17 \pm 3,92$ horas.

Em estudos realizados em ratos por BROCCO et al. (2008) e CAMARGO et al. (2013) sugeriu-se uma ação antimicrobiana da lidocaína quando utilizada em solução abdominal para casos de peritonite. Neste estudo, não foram introduzidos antibióticos nas soluções abdominais, apenas no tratamento sistêmico. Esta característica da lidocaína pode ser considerada como altamente vantajosa no combate in loco da infecção abdominal, além da sua função clássica de anestésico local, com efeito antiinflamatório (KAHOKEHR et al., 2011; BERTOGLIO et al. 2012; PERNIOLA et al. 2014), promovendo analgesia visceral e consequente retorno/manutenção da motilidade de forma precoce. Verificou-se, neste estudo, que os animais que receberam lidocaína junto à solução de lavagem abdominal apresentaram a melhor evolução clínica dos grupos observados, sem apresentar efeito colateral. Verificou-se recuperação de $90 \%$ dos animais submetidos à indução de peritonite fecal durante os 12 dias de avaliação experimental. 
No que se refere a heparina, sabe-se que a mesma pode ser benéfica quando associada à solução de lavagem peritoneal por suas características de redução de aderências, favorecendo o combate da infecção peritoneal (PEJLLER 1988; KEMENT et al., 2011; ARIMATEIA 2011; SILVA et al., 2018). Neste estudo, a associação da heparina à solução de lavagem peritoneal com lidocaína mostrou-se positiva em relação ao Grupo Controle, sendo que $90 \%$ dos animais sobreviveram por 12 dias. Por outro lado, verificou-se que os resultados da adição de heparina à solução de Ringer lactato e lidocaína não demonstrou um evidente efeito sinérgico positivo.

Por outro lado, a adição de carboximetilcelulose à solução de lavagem peritoneal, embora citada pela literatura principalmente na intervenção cirúrgica abdominal, visando impedir ou reduzir as aderências abdominais (LOPES et al., 1999; LOPES et al., 1999; CORRALES 2006; PEREIRA 2016) não se mostrou positiva neste estudo. Não foi verificado superioridade ou efeito sinérgico positivo com sua adição à solução de lavagem peritoneal, sendo que $80 \%$ dos animais sobreviveram os 12 dias de avaliação e as lesões microscópicas de órgãos remotos foram mais evidentes.

A possibilidade de não haver diferença significativa nas variáveis, contagem média de hemácias, hemoglobina, hematócrito e plaquetas pode estar diretamente relacionada com a redução na gravidade do quadro sistêmico, uma vez que as lavagens peritoneais promoveram efeito de melhoria sistêmica. A relação entre a alteração destas variáveis e a gravidade do quadro destes dados é descrita por Lopes et. al (1999); Corrales (2006); Silva et. al (2018). Assim em animais com quadros graves de peritonite possuem correlação da elevação com o agravamento do quadro como comparado por Di Filippo et, al (2009). Sendo a medida inversa, como a não alteração um fator visto como benéfico neste trabalho demonstrado correlação com a lavagem peritoneal. 
Na avaliação físico química do líquido peritoneal, as variáveis de sangue oculto e densidade não demonstraram alterações nos tempos experimentais. Em particular, o sangue oculto pode estar justificado pela presença da sonda abdominal, promovendo pequena lesão de parede, como citado por Rocha et. al., (2007), sem comprometimento clínico, visto que não havia quadro sistêmico de perda sanguínea ou anemia. Quanto à densidade, a ausência de alteração pode estar relacionada ao fato de lavagens seriadas manterem um ambiente em que há reduzido potencial de lesão como cita Leiria (2012), que também não encontrou variações em ambiente de pequena lesão celíaca em equinos.

Na avaliação bioquímica sérica, a dinâmica de elevação dos valores de ureia e creatinina na peritonite é mencionada por Zimmermann et al., (2008), onde encontra correlação direta de elevação com o agravamento do quadro, corroborando com Silva et. al (2018), que relaciona a redução dos valores em animais que passam por mais procedimentos de lavagens peritoneais. Na dinâmica do AST, a elevação é citada por Lhamas (2013), que correlaciona diretamente com o agravamento do quadro de peritonite. Assim, a resposta destas diferentes variáveis, corroboram para o potencial de ataque aos órgão relacionados e podem ser reduzidas proporcionalmente com a sequência de lavagens peritoneais, como demonstrado neste estudo, pelos grupos GL e GLH.

No que se refere o pH do líquido peritoneal, verificou-se redução de pH quando instalada a peritonite fecal, como citado por Lhamas et. al (2014), que demonstra a relação de ambiente mais ácido na peritonite séptica. Verificou-se que os tratamentos representaram boa influência em manter o $\mathrm{pH}$ mais elevado e o ambiente peritoneal com melhor qualidade. A lavagem da cavidade com Ringer lactato apenas (GC) atrasou o controle do $\mathrm{pH}$ peritoneal, sendo que, apenas no quinto dia, os valores de $\mathrm{pH}$ se aproximaram dos valores dos animais tratados com soluções, quando $80 \%$ dos animais já haviam entrado em óbito. Sendo que pH menores (mais ácidos) dosados no líquido peritoneal estão fortemente relacionados a indício de processos 
sépticos (HOOGMOED et. al 1999; MARSHALL \& BLIKSLAGER 2019), uma vez que a indução foi conhecidamente com material de origem séptica mimetizando a situação real, as soluções testadas demonstraram seu potencial na elevação do $\mathrm{pH}$, demonstrando que quanto maior a efetividade na elevação do $\mathrm{pH}$ menor os danos locais e sistêmicos, condições estas desejáveis para solução de lavagem peritoneal.

A proteína peritoneal possui uma dinâmica que relaciona a inflamação ao aumento da permeabilidade, resultando desta forma na elevação da concentração de proteínas no líquido peritoneal (Lhamas et al., 2014). Neste estudo, demonstrou-se que quanto mais elevada a concentração de proteínas peritoneais, pior a condição inflamatória abdominal, como também demonstrado em equinos por Oldeiros et al., (2019), evento ocorrido no GC, em relação aos grupos tratados e de acordo com o descrito por Di Fillipo et. al., (2012); Alonso (2013) \& Oldeiros et. al (2019), em equinos. Ficou demonstrada a importância das lavagens peritoneais para a redução da proteína peritoneal, removendo os fatores pró-inflamatórios peritoneais, melhorando a inflamação e a qualidade do ambiente abdominal. Assim a redução na proteína abdominal é demonstrada como peça fundamental no combate a inflamação peritoneal, atuando principalmente na redução da permeabilidade. Quando abordada a dosagem desta variável deve ser acompanhada em conjunto com outros fatores como prognóstica da efetividade da reversão ou acentuamento do quadro inflamatório abdominal (JOHN F. MARSHALL \& BLIKSLAGER 2019 \& OLDEIROS et al 2019). Desta forma os tratamentos demonstraram eficácia na redução com ênfase para solução que associava apenas lidocaína ao ringer com lactato, já que o mesmo quando utilizado sozinho não demonstrou efetividade semelhante.

Quanto à glicose peritoneal, verificou-se a redução promovida pela lavagem, podendo ser avaliado por dois pontos, um vez que mecanicamente há o transporte do conteúdo para o meio externo e no segundo como indicativo da redução na inflamação abdominal, reduzindo por consequência a permeabilidade peritoneal. A elevação e manutenção de níveis mais elevados é 
um indício de agressão peritoneal como citado por Daves (2003) \& Lhamas et al. (2014). Sendo que a redução não acontece espontaneamente a menos que a agressão seja reduzida, as lavagens peritoneais com as soluções propostas demonstraram efeitos benéficos, demonstrando indícios de redução na agressão e consequentemente menor perfusão de glicose para o abdômen diretamente em consequência das lavagens seriadas (SILVA et al 2018), ainda que mesmo em lavagem abdominal seriada apenas com Ringer Lactato esta resposta não foi tão efetiva, quanto a associação com lidocaína e a lidocaína associado à heparina, demonstrando o potencial destas soluções no combate à agressão peritoneal.

A celularidade peritoneal reflete diretamente o nível de permeabilidade no combate a inflamação local e infecção. A elevação na contagem global de células totais (nucleadas), bem como outros componentes celulares do processo inflamatório, a exemplo dos macrófagos e neutrófilos, dentro as principais células epiteliais ativas, é forte indicio de agressão peritoneal (DI FILIPPO et al., 2012; LHAMAS et al., 2014; SILVA et al., 2018). Assim, os resultados encontrados no GC demonstram que, mesmo lavando a cavidade peritoneal em série, somente a solução de Ringer lactato não é suficiente para a redução da celularidade. Já os grupos que tinham em sua composição a lidocaína (GL e GLH) apresentaram expressivas reduções de células nucleadas peritoneais, visto que o alvo de efeitos do fármaco, provavelmente, são as células mesoteliais (VINTEN-JOHANSEN, 2004; PERNIOLA, et al., 2014), com efeito antiinflamatório, reduzindo células inflamatórias, incluindo monócitos, macrófagos e neutrófilos (HOLLMANN \& DURIEUX, 2000; COHEN, 2002; KAHOKEHR et al., 2011). Por outro lado, o grupo GLHC apresentou pior desempenho em função da presença da carboximetilcelulose que, ao produzir membrana com maior viscosidade, cria a necessidade de ser fagocitada, mantendo uma maior celularidade inflamatória como já descrito por Lopes et al. (1999); Mendes et al. (2000); Pereira (2016). 
Avaliando os achados macroscópicos, as aderências são consideradas um dos maiores fatores de complicação na peritonite em equinos (LUNDBERG, 2014), levando os animais a quadros de dor que vão de leve a intensa e que podem culminar com óbito. Já Oldeiros et. al (2019) cita que os quadros mais agravados de peritonite possuem forte ligação com as aderências abdominais, assim como demonstrado por Silva et. al (2018), no trabalho ficou demonstrado o potencial de lavagens peritoneais com as soluções propostas, reduzindo a presença de aderências abdominais, entre órgãos e órgão e a parede abdominal. Os resultados de redução nas aderências abdominais se diferem dos encontrados por Brocco et. al (2012), que obteve resposta significativa apenas associando a lavagem ao enxugamento da cavidade em ratos. Quando comparado o GC lavado apenas com Ringer Lactato e os grupos de tratamento (GL, GLH e GLHC), estes demonstram significativa redução quando comparado ao GC, com melhores resultados na redução de aderências, com melhor desempenho nos grupos onde adicionou-se apenas a lidocaína e lidocaína com heparina à solução de RL. Avaliando-se os achados histológicos deste estudo, demonstram-se, nos grupos não tratados e nos grupos tratados apenas com solução de Ringer lactato, lesões em fígado e rim, órgãos-alvo de ataque nos quadros de SIRS/SEPSE (BROCCO et al., 2012; PINTO et al., 2012). Evidencia-se, então, o efeito hepatoprotetor e redutor de apoptoses renais nos animais que receberam lidocaína junto à solução de lavagem peritoneal, corroborando com a literatura (COHEN, 2002; VINTENJOHANSEN, 2004; OLIVEIRA et al, 2010; KAHOKEHR et al., 2011; PERNIOLA, et al., 2014). A inclusão de outros fármacos, como heparina e carboximetilcelulose, não demonstrou efeito protetor e apresentou características histológicas negativas, o que pode inferir um potencial de sobrecarga de medicamentos sobre os órgãos (KAHOKEHR et al., 2011; MURI et al., 2010; PERNIOLA et al., 2014).

É possível ressaltar que a lavagem peritoneal, em todos os grupos experimentais, apresentou resposta positiva em comparação com os animais que não foram lavados e, verificou-se que, 
quanto mais ciclos de lavagens, mais rapidamente os animais retornam à condição de conforto, ou seja, normalizava-se o consumo de alimento sólido e ingestão de água, assim como o ganho de peso e sobrevida. Esses achados assemelham-se com o encontrado por Silva et.al (2018), onde equinos que suportaram o quadro de peritonite e puderam ser lavados mais vezes, apresentaram melhores respostas frente ao quadro de peritonite séptica. Da mesma forma, Oliveira et.al (2014) e Ruivo et.al (2018) apresentam a terapia de lavagem peritoneal como fator de sucesso nos casos de peritonite séptica em equinos.

\section{CONCLUSÃo}

Conclui-se que a lavagem peritoneal em cobaias com peritonite fecal é benéfica quando associada ao tratamento sistêmico, visto que sem ela todos os animais foram a óbito em menos de 24 horas. Quando associados a lidocaína, heparina e carboximetilcelulose o impacto significativo na sobrevida foi demonstrado bem como na redução de aderências abdominais, sendo a associação de ringer lactato com lidocaína e ringer lactato com lidocaína e heparina as soluções que demonstraram os melhores desempenhos, sendo a solução de ringer lactato com lidocaína considerada mais adequada vista a somatória dos resultados clínicos e estatísticos. 


\section{REFERÊNCIAS BIBLIOGRÁFICAS}

ACUNA,L. et al. Morphometric and Histopathologic Changes in Skeletal Muscle Induced for Injectable PLGA Microparticles. International Journal of Morphology. 29 p. 403-408, 2011.

AITKEN,M.R. et al. 2015. Outcome of surgical and medical management of cecal impaction in 150 horses (1991-2011). Veterinary Surgery. 44 p. 540-546.

ALONSO, J.M. Avaliação da reatividade peritoneal e das concentrações plasmáticas e peritoneais da ceftriaxona após administração intraperitoneal por cateter Tenckhoff em equinos. 56f. Botucatu, SP. Tese (Doutorado em Medicina Veterinária) - Programa de Pós-Graduação em Biotecnologia Animal, Faculdade de Medicina Veterinária e Zootecnia, Universidade Estadual Paulista, 2016.

ALVES,G.E. Lavagem peritoneal: benefícios, limitações e riscos in: https://www.researchgate.net/publication/267854300_Lavagem_peritoneal_benefcios_limitaes_e_ri scos\#full-text, 2002. Acesso em: 10/05/2018.

ANDERSON, S.L. et al. Occurrence of incisional complications and associated risk factors using a right ventral paramedian celiotomy incision in 159 horses. Veterinary Surgery. 40 p. 82-89, 2011.

ANDRADE A.P.S.C.; OLIVEIRA, R.S. Animais de Laboratório: criação e experimentação. Editora FIOCRUZ, p.388, 2002.

ANDRADE, S.F; Manual de Terapêutica Veterinária, $3^{\text {a }}$ edição São Paulo: Editora Roca, 912 p., 2008.

ARIMATEIA. D. S. Influência do tempo e dose de heparina em modelo de peritonite aguda. 2011. 53f. Dissertação (Mestrado em Bioquímica) - Programa de Pós-Graduação em Bioquímica, Universidade Federal do Rio Grande do Norte, Natal, 2011.

AYDIN, O.N.; EYIGORT, M.; AYDIN, N. Antimicrobial activity of ropivaciane and other local anesthetics. European Journal of Anesthesiology, v 18, p. 687-694, 2001.

AYSAN, E. et al.. Effects of contractubex on the prevention of postoperative peritoneal adhesion. J Surg Res. v. 164, n. 2, p. 193-7, 2010.

BAHADIR, I. et al. Intra-abdominal use of taurolidine or heparin as alternative products to an antiadhesive barrier (Seprafilm) in adhesion prevention: an experimental study on mice. Dis Colon Rectum., v.50, n. 12, p. 2209-14, 2007.

BEAUSSIER, M. et al. Continuous preperitoneal infusion of ropivacaine provides effective analgesia and accelerates recovery after colorectal surgery: A randomized, double-blind, placebocontrolled study. Anesthesiology. 107 p. 461-468, 2007.

BERTOGLIO, S. et al. The postoperative analgesic efficacy of preperitoneal continuous wound infusion compared to epidural continuous infusion with local anesthetics after colorectal cancer surgery: A randomized controlled multicenter study. Anesth Analg. 115 p. 1442-1450, 2012. 
BOOTHE, D.M. Drogas analgésicas, antipiréticas e antiinflamatórias. In: ADAMS, H.R. Farmacologia e Terapêutica em Veterinária. 8. ed., Rio de Janeiro: Guanabara Koogan, p.361, 2003 ,

BORGHESAN, A. C. Avaliação da tromboflebite jugular experimental em equinos tratados com heparina. 87f. Botucatu, SP. Dissertação (Mestrado em Medicina Veterinária) - Programa de Pós-Graduação em Medicina Veterinária, Faculdade de Medicina Veterinária e Zootecnia, Universidade Estadual Paulista, 66p, Botucatu, 2010.

BROCCO, M. C. et al. Efeito da lavagem peritoneal com bupivacaína na sobrevida de ratos com peritonite fecal. Revista Brasileira de Anestesiologia, v. 58, n.5, p. 470-479, 2008.

CAMARGO, M. G. et al. Influence of the peritoneal lavage with bupivacaine on the survival and resistance of colonic anastomoses performed under fecal peritonitis in rats. Revista Acta Cirúrgica Brasileira, v. 28, n.11, p. 783-787, 2013.

CARNEIRO, B. G. M. C et al . Comparison between several treatments for fecal peritonitis in rat. Rev. Col. Bras. Cir., Rio de Janeiro, v. 29, n. 1, p. 43-48, 2002.

CASTEL-BRANCO, M. M. et al. As bases farmacológicas dos cuidados farmacêuticos: o caso dos AINEs. Acta Farmacêutica Portuguesa, vol. 2, n. 2, p. 79-87, 2013.

CHACAR, F.C. et al. A. Diálise peritoneal em cães e gatos. Vet. e Zootec.; v. 21, n. 2, p. 229-237, 2014.

CHALKIADAKIS, G. et al. The effect of heparin upon fibrinopurulent peritonitis in rats. Surg. Gynecol. Obstet., v.157, p.257-260, 1983.

COHEN, J. The immuunopathogenesis of sepsis. Nonste roidal anti-inflammatory drug associated right dorsal colitis in the horse. Nature, v. 420, p. 880- 891, 2002.

COOPER, R. L., LABATO M. A. Peritoneal dialysis in veterinary medicine. Vet Clin North Am Small Anim Pract. v. 41, p. 91-113, 2011.

CORRALES, F. Uso intraperitoneal de carboximetilcelulose/hialuronato de sódio e da vitamin D e na prevenção de aderências pós-operatórias: Estudo experimental em ratos. 52f. Caxias do Sul, RS. Dissertação (Mestrado em Medicina) - Programa de Pós-Graduação em Medicina: Cirurgia, Faculdade de Medicina, Universidade Federal do Rio Grande do Sul e Universidade de Caxias do Sul, 2006.

DAS, K. C.; MISRA, H. P. Prevention of reperfusion lung injury by lidocaine in isolated rat lung ventilated with higher oxygen levels. J Postgrad Med. v. 49(1), p. 17-20, 2003. 
DAUGIRDAS, J.T.; BLAKE, P.G.; ING, T.S. Manual de Diálise. 3. ed. Rio de Janeiro: Editora Médica e Científica LTDA, p. 2003.

DAVIS J.L. 2003. Treatment of peritonitis. The Veterinary Clinics - Equine Practice. 19:765778.

DAVIS, J. L. Nonesteroidal anti-inflamatory drug associated right dorsal colitis in the horse. Equine veterinary education, v. 29, n. 2, p. 104-113, 2017.

DEHEER, H.L.;PARRY, B.W.; GRINDEM, C.B. Peritoneal fluid in Diagnostic citology and hematologyof the horse. 2. ed. Massachusetts: Editora Mosby, p. 127, 2002.

DICKINSON, C. Peritonitis. In: REED, S.M.; BAYLY, W.M.; SELLON, D.C. Equine Internal Medicine. 2. ed., St. Louis: Elsevier Inc., p.941-945, 2004

DINARELLO C.A.; GELFAND J.A.; WOLFF S.M. Anticytokine Strategies in the Treatament of the Systemic Inflamatory Response Syndrome. JAMA. v. 269, n.14, p. 1829-1835, 1993.

DIOGO-FILHO, A. et al. Avaliação das aderências pós-operatórias em ratos submetidos a peritoniostomias com tela de polipropileno associada à nitrofurazona. Arq Gastroenterol. v. 41, n.4, p. 245-2499, 2004.

DI FILIPPO, P.A. et al. Características celulares e bioquímicas do líquido peritoneal de equinos submetidos à obstrução experimental do duodeno, íleo e cólon maior. Arquivo Brasileiro de Medicina Veterinária e Zootecnia. v.61, n.6, p.1281-1289, 2009.

DIZEREGA, G. S.; RODGERS, K. E. The peritoneum. New York: Springer-Verlag, Cap. 10: Prevention of post-operative adhesions: p.307-369, 1992.

EGGLESTON, R. B.; MUELLER, P. O. Prevention and treatment of gastrointestinal adhesions. Vet Clin North Am Equine Pract, v. 19, p. 741-763, 2003.

EURELL, J.A.; FRAPPIER, B.L. Histologia veterinária de Dellmann. 6. ed. Barueri: Manole, 2012.

FARIA, E.P.; MARQUES JR.; A.P.; ALVES, G.E.S. Características celulares e bioquímicas do líquido peritoneal de equinos submetidos à peritonite experimental. Arquivo Brasileiro de Medicina Veterinária e Zootecnia, v. 51, n. 4, p. 335-344, 1999.

FROLLINI, B. M. C., E. Carboximetilcelulose como agente de estabilização de suspensões cerâmicas. Anais do 10o Congresso Brasileiro de Polímeros - Foz do Iguaçu, PR Outubro/2009, disponível em: https://www.ipen.br/biblioteca/cd/cbpol/2009/PDF/795.pdf Acesso em: 30/07/2017. 
GALLOS, G. et al. Local anesthetics reduce mortality and protect aganist renal and hepatic dyffuntion in murine septics peritonitis. Anestesiology. v. 101, n 4, p. 902-911 2004.

GUSSO, J.E. Peritonite séptica em um cão. 37f. Santa Maria, RS. Monografia (Residência em Medicina Veterinária) - Programa de Residência Médico Veterinária, Universidadde de Santa Maria, 2018.

HA, U. et al. Hyaluronic acid-carboxymethylcellulose reduced postoperative bowel adhesions following laparoscopic urologic pelvic surgery: a prospective, randomized, controlled, single-blind study. BMC Urology. v. 16, p. 28, 2016).

HOLLMANN M. W., DURIEUX M. E. Local anesthetics and the inflammatory response. Anesthesiology ; v. 93, n. 3, p. 858-75, 2000.

HOOGMOED, L.M.V. et al. Evaluation of peritoneal fluid $\mathrm{pH}$, glucose concentration, and lactate dehydrogenase activity for detection of septic peritonitis in horses. Journal of the American Veterinary Medical Association. v. 214(7),p. 1032-1036,1999.

ISUN, Z. et al. Phacocytic and intestinal endothelial and epithelial barrier function during the early stage of small intestinal ischemia and reperfusion injury. Shock, v 13, p. 209-216, 2000.

JUNQUEIRA, L. C.; CARNEIRO, J. Histologia Básica. O trato digestivo. 10. ed. Rio de Janeiro: Guanabara Koogan S. A. p. 284, 2004

KAHOKEHR, A. et al. Intraperitoneal local anesthetic improves recovery after colon resection: A double-blinded randomized controlled trial. Ann Surg. v. 254, p. 28-38, 2011.

KELLER, STUART D. - Equine Colic Management. BVSc MACVSc (Eq Surg) 2015. Disponível em:http://www.ava.com.au/sites/default/files/Equine\%20Colic\%20\%20Management_Stuart\%20Kel ler.pdf. Acesso em 20/10/2017.

KEMENT, M. et al. Heparin for adhesion prevention: comparison of three different dosages with Seprafilm in a murine model. Int J Surg. v. 9, n. 3, p. 225-8, 2011.

KEUBLER, F. J. et al. Differencial alterations in intestinal permeability after trauma-hemorrhage. Journal of Cirurgical Research, v 112, p. 198-204, 2003.

LABATO, M. A. Peritoneal dialysis. In: Bartges J, Polzin DJ. Nephrology and urology of small animals. Wiley: Blackwell Ltda, p.293-305, 2011.

LASKOSKI L.M. et al. Lavagem peritoneal em uma égua com peritonite secundária a ruptura uterina - relato de caso. In: Anais do IX Congresso Brasileiro de Cirurgia e Anestesiologia 
Veterinária (Rio de Janeiro, Brazil). Jornal Brasileiro de Ciência Animal. v. 3(Supl 6), p. 167-170, 2010.

LEE J. M. B. S. Antiadhesive effect of mixed solution of sodium hyaluronate and sodium carboxymethylcellulose after blow-out fracture repair. J Craniofac Surg. v. 23, p. 1878-83, 2012.

LEE, R. et al. Retrograde infusion of lidocaine or L-arginine before reperfusion reduces myocardial infarct size. Ann Thorac Surgery. v. 65, n. 5, p. 1353-1359, 1998.

LEIRA P.A.T. et al. Adesiólise peritoneal trans-cirúrgica seguida de lavagem peritoneal e infusão de solução de carboximetilcelulose 1\% (SCMC 1\%) através de tubo de silicone implantado na cavidade abdominal. In: XIII Conferência Anual da ABRAVEQ. p.984, 2012.

LHAMAS, et al. Avaliação do líquido peritoneal de equinos. Ciência Animal. v. 24, n. 2, p. 03-12, 2014.

LOPES, M.A.F. et al. Exame do líquido peritoneal e hemograma de equinos submetidosà laparotomia e infusão intraperitoneal de carboximetilcelulose. Rev. Ciência Rural, Santa Maria, v.29, n.1, p. 79-85, 1999.

LUNDBERG , Z. Peritonitis in Horses - a Retrospective Study of 69 Cases Admitted to a University Hospital During a Ten Year Period. Degree in Veterinary Medicine, code: EX0736, p 41, 2014.

MACIEL, A. M. D. R., XAVIER, V. F. Utilização de Imipenem em equinos com risco iminente de peritonite. Sinapse Múltipla, v. 6, n.1, p. 103-103, 2017.

MARSHALL, J.F.; BLIKSLAGER, A.T. in Equine Surgery. 5. ed. 2019

MAZAFFARI, A. A., et al. A comparative study on the adverse effects of flunixin, ketoprofen and phenylbutazone in miniature donkeys: haematological, biochemical and pathological findings. N. Z. Vet. J. v. 58, p. 224-228, 2010.

MENDES, L. C. N. et al. Experimental peritonits in horses. Hematological and Biochemistry aspects. Brazilian Journal of Veterinary Research Animal Science, v.37,n.2, p.146-152, 2000.

MELGAÇO S. S. C. et al. Nefrotoxicidade dos anti-inflamatórios não esteroidais. Medicina (Ribeirão Preto); v. 43(4), p. 382-90, 2010.

MURI, E.M.F.; SPOSITO, M.M.M.; METSAVAHT, L. Farmacologia de drogas vasoativas. Acta fisiatr, v. 17(1), p. $22-27,2010$ 
MUSCH, W. M.; WALSH-REITZ, M. M.; CHANG, B. E. Roles os ZO-1, occluding and actin in oxidant-induced barrier disruption. American Journal of physiology gastrointestinal and liver physiology, v. 290, p. 222-231, 2005.

NEVES J.P.L. et al. Fístula enterocutânea em égua - Relato de caso. Vet. e Zootec. v. 23(2), p 209-214, 2016.

NISHINA, K. et al. Does Early Posttreatment with Lidocaine Attenuate Endotoxin-induced Acute Lung Injury in Rabbits. Anesthesiology. v. 83(1), p. 169-177, 1995.

Nógrádi N, Tóth B, Macgillivray KC. Peritonitis in horses: 55 cases (2004-2007). Acta Vet Hung $2011 ; 59 ; 2$

ODELROS, E. et al. Peritonite idiopática em cavalos: um estudo retrospectivo de 130 casos na Suécia (2002-2017). Acta Vet Scand. v. 61, n. 18, 2019.

OLIVEIRA, C. M. B., ISSY, A. M., SAKATA, R. K. Lidocaína por via venosa intraoperatória. Rev. Bras. Anestesiol., Campinas , v. 60, n. 3, p. 325-332, 2010 .

OLIVEIRA, C.A.A. et al. Hematological and blood gas parameters' response to treadmill exercise test in eventing horses fed different protein levels. Journal of Equine Veterinary Science, v. 34, p. 1279-1285, 2014.

OLIVEIRA, N.F.O. et al. Lavado peritoneal como adjuvante à terapia da peritonite em equinos.

Ciência Veterinária nos Trópicos, Recife, v. 17, n. 3, p. 80, 2014.

OLIVEIRA, L.S. et al. Avaliação da dor em pacientes críticos por meio da Escala Comportamental de Dor. BrJP, v. 2, n. 2, p. 112-116, 2019.

ONCEL, M. et al. Comparison of a novel liquid (Adcon-P) and a sodium hyaluronate and carboxymethylcellulose membrane (Seprafilm) in postsurgical adhesion formation in a murine model. Dis Colon Rectum, v. 46, p. 187-191, 2003.

PACHECO, J. F. et al. Prevenção de Aderências Pélvicas: Estudo Experimental em Ratas com Diferentes Modalidades Terapêuticas. Revista Brasileira de Ginecologia e Obstetrícia, v. 25, n. 5, p. 359-364, 2003.

PAGLIOSA, G. M.; ALVES, G. E. S. Fatores predisponentes das complicações incisionaisde laparotomias medianas em equinos. Revista Cienc. Rural, v. 34, n. 5, p. 1655-1659, 2004.

PALMA, M. L. M.; FOZ FILHO, R. P. P. Aderências intra-abdominais em equinos. Rev. Educ. Contin, v. 8, n. 2, p. 123-134, 2005.

PATRICK, S.; VILLANO, J. The Laboratory Rat. 2 Nd. ed., CRC:Boca Raton, Flórida, 2013. 
PEJLER, G. Why does heparina bind antithrombin? Upssala: Swedish University of Agricultural Sciences Faculty of Veterinary Medicine, Thesis, Doctorate, p. 59, 1988.

PEREIRA, A. M. Principais Doenças das cobaias in: ANDRADE, A., P. S. C.; OLIVEIRA, R. S., Animais de Laboratório: criação e experimentação. Editora FIOCRUZ, p.388, 2002.

PEREIRA, S.C. Peritonite Decorrente de Síndrome Cólica em Equinos: Diagnóstico, tratamento e prevenção. 35 f. Patos, PB. Monografia (Graduação em Medicina Veterinária) - Universidade Federal de Campina Grande, Centro de Saúde e Tecnologia Rural, 2016.

PERNIOLA, A. et al. Intraperitoneal Local Anesthetics Have Predominant Local Analgesic Effect: A Randomized, Double-blind Study. Anesthesiology, v. 121(2), p. 352-361, 2014.

PIHL T.H. et al. Influence of disease process and duration on acute phase proteins in serum and peritoneal fluid of horses with colic. Journal Veterinary Internal Medicine. v. 29(2), p. 651-658, 2015.

PINTO, C.F. et al. A sepse como causa de lesão renal aguda: modelo experimental. Rev Esc Enferm, v. 46(Esp), p. 86-90, 2012

PLUNKETT, S. J. Procedimentos de emergência em pequenos animais. 2. ed. Rio de Janeiro: Revinter, p. 204-210. 2006.

POLLOCK, P.J, et al. Effects of surgery on the acute phase response in clinically normal and diseased horses. Veterinary Record, v.156, p.538-542, 2012.

RAFEE, M. A. et al. Guinea pigs as an animal model for sciatic nerve injury. Neural Regen Res 12(3):452-457, 2017.

ROCHA, E. J. N., et al. Avaliação laboratorial de líquido peritoneal e análise bioquímica sérica, resultante da abdominocentese em equinos. Revista científica eletrônica de medicina veterinária - ano IV, número, Garça, 2007.

RODRIGUES, F. H. O. C., et al. Inibição da formação de abscesso abdominal em rato. Mortalidade por sepse. Arq Gastroenterol, v. 42, n. 1, p 50-54, 2005.

RUIVO, M. R. B. A., Baccarin, R. Y. A., Spagnolo, J. D., Souza, A. F. de, Nardin Neto, E., \& Ambrósio, A. M. (2018). Uso da lavagem peritoneal no pós-operatório de abdômen agudo em equinos. In Anais. Jaboticabal: UNESP/FCAV, 2018.

SALLES, M. J. C. et al. Síndrome da resposta inflamatória sistêmica/sepse - revisão e estudo da terminologia e fisiopatologia. Revista da Associação Médica Brasileira, v. 45 (1), p. 86-92, 1999. 
SHELL, K. et al. Effects of metronidazole and flunixin meglumine on equine right dorsal colonic mucosa. J. Vet. Intern. Med. v. 28, p. 1105, 2014.

SILVA, T.J.F. et al. Avaliação anatomopatológica das complicações da peritonite fecal em equinos tratados com lavagem peritoneal. Acta Scientiae Veterinariae, v. 46(Suppl 1), p. 319, 2018.

TOMORI, H. et al. Protective effects of lidocaine in hepatic ischemia/reperfusion injury in vitro. Transplant Proc.; 30(7): 3740-2, 1998.

TORRES, O. J. M., et al. Peritonite fecal em ratos: eficácia da lavagem da cavidade peritoneal com solução de cloreto de sódio a 0,9\%. Acta Cir. Bras., vol.14, n.2, 1999.

TORRES NETO, J. R. et al. Uso da peritoneostomia na sepse abdominal. Rev bras. colo-proctol, v. 27, n.3, p.278-283, 2007.

TRENT, A. M. The peritoneum and peritoneal cavity. In: KOBLUK, C. N. The horse diseases e clinical management. Philadelphia: Saunders, p. 373-404, 1995.

VICENTE, D., PÉREZ-TRAELLO, E. Tetraciclinas, sulfamidas y metronidazol, Enfermedades Infecciosas y Microbiología Clínica, v.28, n. 2, 122-130, 2010.

VINTEN-JOHANSEN, J: Involvement of neutrophils in the pathogenesis of lethal myocardial reperfusion injury. Cardiovasc Res. v. 61, p. 481-497 2004.

VILOS, C. et al. Preclinical Development and In Vivo Efficacy of Ceftiofur-PLGA Microparticles. PLoS ONE, v 10(4), p. 1-19, 2015.

WEBSTER, C. R. L. Farmacologia Clínica. São Paulo: Roca, p.62-63, 2005.

WHITE II, N. A. The equine acute abdômen. Philadelphia: Lea \& Febiger, 434p., 1990.

ZIMMERMANN, Marina et al . Peritonite em cães. Cienc. Rural, Santa Maria , v. 36, n. 5, p. 16551663, Oct. 2006 